Supporting Information for

\title{
Access to spirocyclic benzothiophenones with multiple stereocenters via an organocatalytic cascade reaction
}

\author{
Bedřich Formánek, ${ }^{\mathrm{a}}$ Jiř́i Tauchman, ${ }^{\mathrm{a}}$ Ivana Císařová, ${ }^{\mathrm{b}} \mathrm{Jan}$ Veselý*,a \\ ${ }^{a}$ Department of Organic Chemistry, Faculty of Science, Charles University, Hlavova 2030/8, 12843 Prague 2, \\ Czech Republic, e-mail: jxvesely@natur.cuni.cz,web: http://orgchem.cz/vesely/ \\ ${ }^{b}$ Department of Inorganic Chemistry, Faculty of Science, Charles University, Hlavova 2030/8, 12843 Prague 2 , \\ Czech Republic
}




\section{Table of Contents}

1 The complete survey of the reaction conditions .................................................................S3

2 X-Ray analysis ........................................................................................................................... S6

3 Copies of NMR spectra .............................................................................................................510

4 Chiral HPLC chromatograms..................................................................................................S44 


\section{The complete survey of the reaction conditions}

The ee of each diastereomer was determined by chiral HPLC with a column IC, $n$-heptane: $i \operatorname{PrOH}=90: 10, \mathrm{~V}=1 \mathrm{~mL} / \mathrm{min}, \mathrm{T}_{\text {oven }}=25^{\circ} \mathrm{C}, 254 \mathrm{~nm}$.

Table S1: Solvent screening

\begin{tabular}{|c|c|c|c|c|c|}
\hline \multirow{2}{*}{$\frac{1 \mathrm{a}(1 \text { equi }}{\text { Entry }}$} & $\mathrm{CO}_{2} \mathrm{Et}$ & equiv.) & $\begin{array}{r}\text { Catalyst I (20 } \\
\text { 2,4-DNBA (40 } \\
\text { solvent } \\
\text { RT }\end{array}$ & \multicolumn{2}{|c|}{$3 \mathbf{a}$} \\
\hline & Solvent & Time [d] & Yield [\%] $^{a}$ & $d r[\%]^{\mathrm{b}}$ & $e e[\%]^{c}$ \\
\hline 1 & toluene & 4 & 85 & $10.8 / 15.0 / 1$ & $72 / 5 / 34$ \\
\hline 2 & $\mathrm{CHCl}_{3}$ & 7 & 60 & $7.4 / 5.4 / 1$ & $85 / 28 / 14$ \\
\hline 3 & DMF & 4 & 82 & $7.7 / 3.4 / 1$ & $88 / 54 / 31$ \\
\hline 4 & $\mathrm{MeOH}$ & 7 & 76 & $2.5 / 2.8 / 1$ & $79 / 26 / 42$ \\
\hline 5 & $\mathrm{Et}_{2} \mathrm{O}$ & 6 & 84 & $5.5 / 2.8 / 1$ & $79 / 22 / 74$ \\
\hline 6 & MTBE & 4 & 86 & $12.8 / 5.6 / 1$ & $87 / 15 / 72$ \\
\hline 7 & THF & 3 & 92 & $7.6 / 2.3 / 1$ & $93 / 40 / 71$ \\
\hline 8 & 1,4-dioxane & 4 & 86 & $13.4 / 4.0 / 1$ & $96 / 47 / 88$ \\
\hline
\end{tabular}

a Isolated overall yield of diastereomers 3aa, 3'aa, 3"aa respectively after column chromatography. ${ }^{b}$ Determined by ${ }^{1} \mathrm{H}$ NMR analysis of crude mixture. ${ }^{\mathrm{c}} \mathrm{Ee}$ of diastereomers determined by HPLC analysis. 2,4-DNBA = 2,4-dinitrobenzoic acid<smiles>[R]c1ccc2nccc([C@@H](N)C3C4CCN3CC4C=C)c2c1</smiles>

III

II $\mathrm{R}^{\prime}=\mathrm{OMe}$<smiles>[R7]N(CC(C)C[C@H](N)CNC1CCCCC1)CC(N)Cc1ccccc1</smiles>

IV R"=Cy, R"'=H V

VII $R^{\prime \prime}=R^{\prime \prime}=E t$<smiles>C=CC1C2CN(C2C)C1[C@H](N)c1ccnc2ccccc12</smiles>

IX<smiles>[X]C(Cc1ccccc1)C(N)C(=O)NC1CCCCC1</smiles>

VI $R^{\prime \prime}=\mathrm{Cy}, \mathrm{R}^{\prime \prime}=\mathrm{H}$

VIII R"=R"'=Et<smiles>NC1CCCCC1N</smiles>

IV' 
Table S2: Catalyst screening

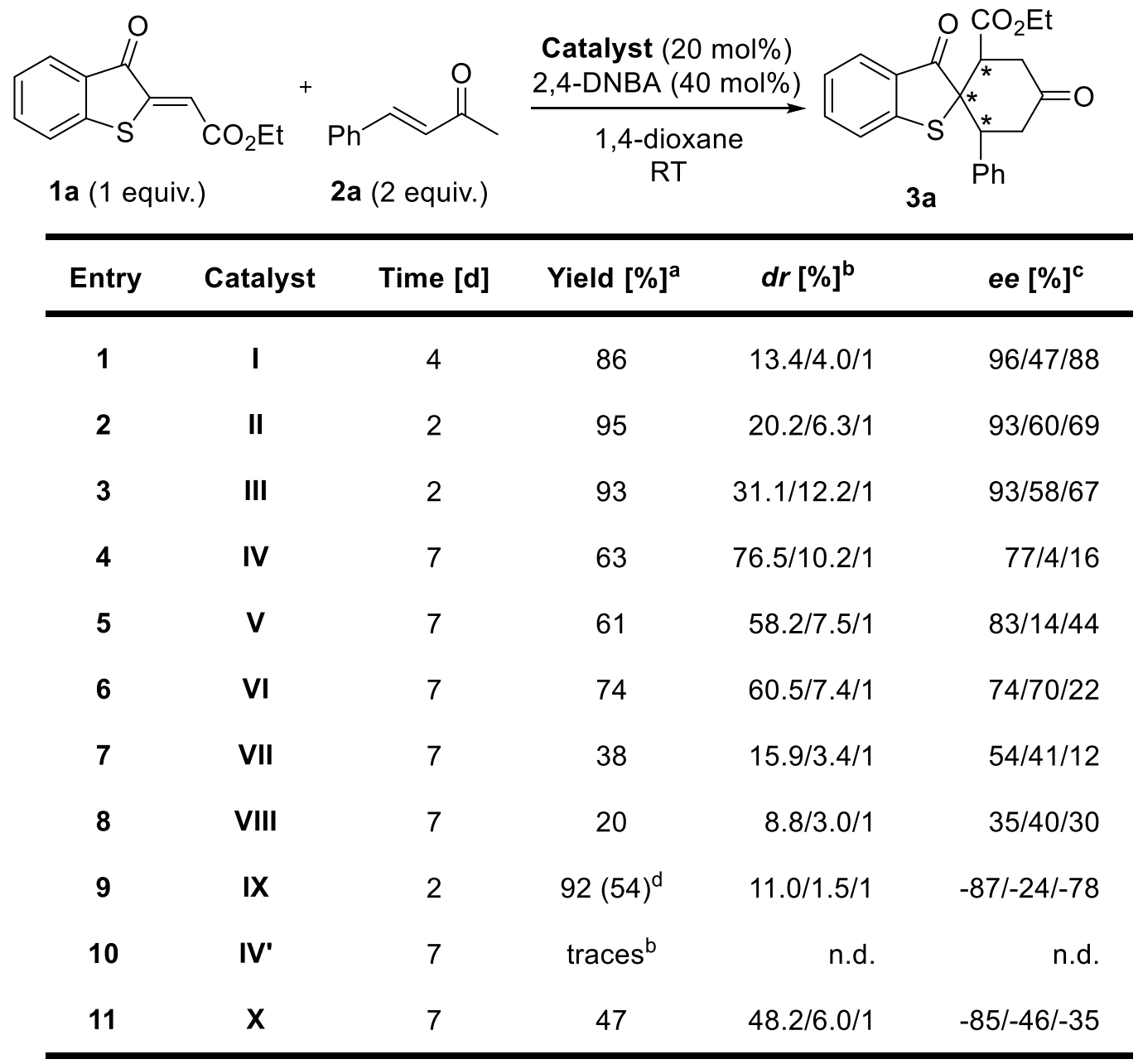

a Isolated overall yield of diastereomers 3aa, 3'aa, 3"aa respectively after column chromatography. ${ }^{b}$ Determined by ${ }^{1} \mathrm{H}$ NMR analysis of crude mixture. ${ }^{c}$ Ee of diastereomers determined by HPLC analysis. ${ }^{d}$ Isolated yield of single diastereomer 3 aa in brackets. 2,4-DNBA = 2,4-dinitrobenzoic acid 
Table S3: Conditions screening

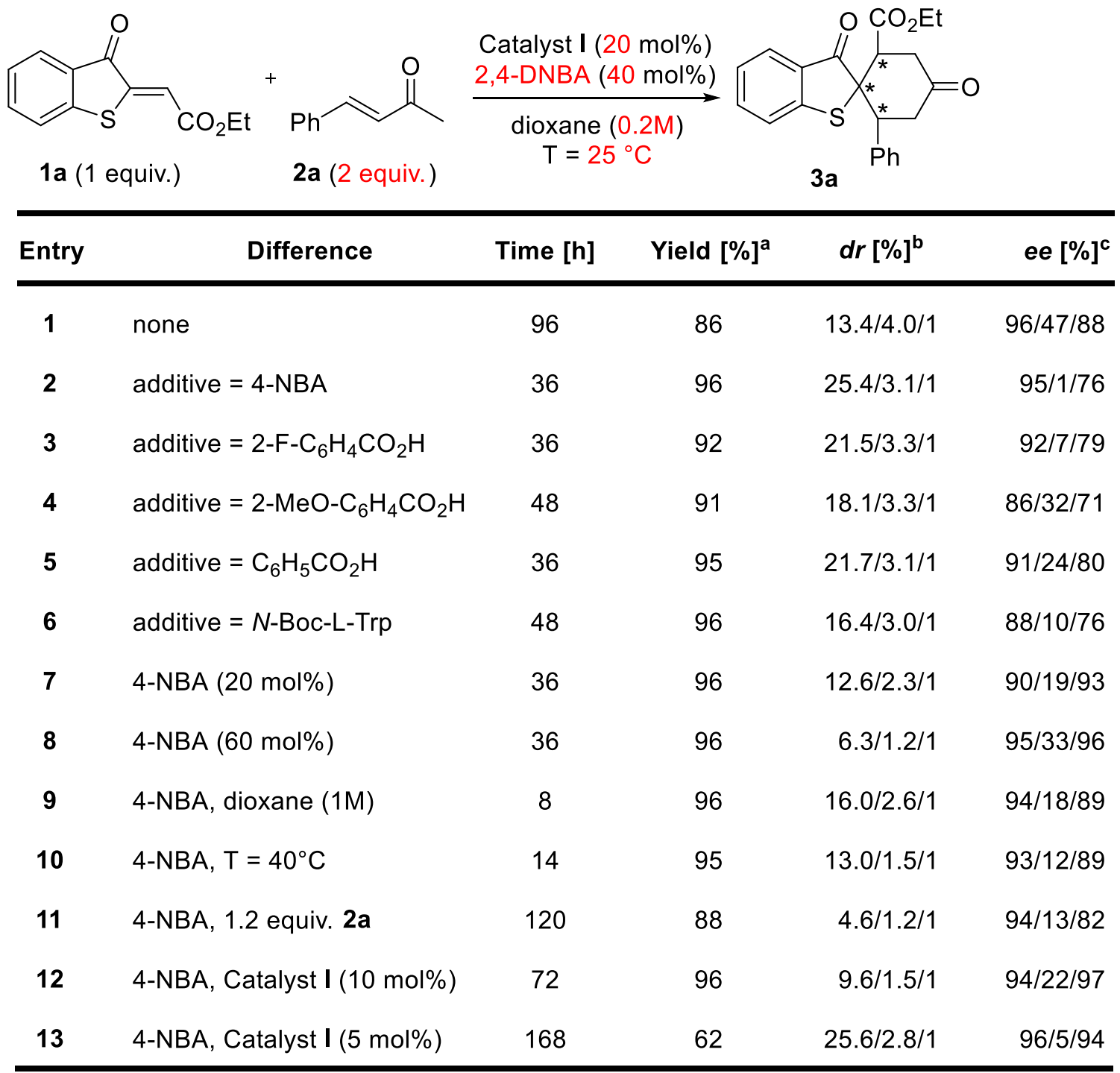

a Isolated overall yield of diastereomers 3aa, 3'aa, 3"aa respectively after column chromatography. ${ }^{b}$ Determined by ${ }^{1} \mathrm{H}$ NMR analysis of crude mixture. ${ }^{c} \mathrm{Ee}$ of diastereomers determined by HPLC analysis. 2,4-DNBA = 2,4-dinitrobenzoic acid, 4-NBA $=4$-nitrobenzoic acid, $N$-Boc-L-Trp $=N$-(tert-butoxycarbonyl)-L-tryptophan 


\section{X-Ray analysis}

\section{Crystal growth}

Compound 3ag was dissolved in $\mathrm{Et}_{2} \mathrm{O}$. Then the hexane vapours were allowed to diffuse into the solution in closed system at room temperature.

\section{Refinement}

Crystal data, data collection and structure refinement details are summarized below and in Table S4.

Crystallographic data for were collected on Bruker D8 VENTURE Kappa Duo PHOTON100 by $\mathrm{I} \mu \mathrm{S}$ micro-focus sealed tube $\operatorname{MoK} \alpha(\lambda=0.71073)$ at a temperature of $150(2) \mathrm{K}$. The structure was solved by direct methods $(\mathrm{XT})^{1}$ and refined by full matrix least squares based on $F^{2}$ (SHELXL2014) ${ }^{2}$. The hydrogen atoms on carbon were fixed into idealized positions (riding model) and assigned temperature factors either $\mathrm{H}_{\mathrm{iso}}(\mathrm{H})=1.2 \mathrm{U}_{\text {eq }}$ (pivot atom) or $\mathrm{H}_{\text {iso }}(\mathrm{H})=1.5 \mathrm{U}_{\text {eq }}$ (pivot atom) for methyl moiety. The absolute structure determination was based anomalous dispersion of $\mathrm{Br}$ atom.

Crystal data for 3ag: $\mathrm{C}_{22} \mathrm{H}_{19} \mathrm{BrO}_{4} \mathrm{~S}, M_{\mathrm{r}}=459.34$; Orthorhombic, P2 ${ }_{1} 2_{1} 2_{1}$, (No 19), $a=$ 11.0046 (4) $\AA, b=11.4721$ (4) $\AA, c=15.6538$ (4) $\AA, V=1976.23$ (11) $\AA^{3}, Z=4, D_{\mathrm{x}}=$ $1.544 \mathrm{Mg} \mathrm{m}^{-3}$, yellow prism of dimensions $0.30 \times 0.16 \times 0.10 \mathrm{~mm}$, numerical absorption correction $\left(\mu=2.21 \mathrm{~mm}^{-1}\right), T_{\min }=0.647, T_{\max }=0.869$; a total of 28071 measured reflections $\left(\theta_{\max }=27.5^{\circ}\right)$, from which 4526 were unique $\left(R_{\text {int }}=0.025\right)$ and 4374 observed according to the $I>2 \sigma(I)$ criterion. The refinement converged $\left(\Delta / \sigma_{\max }=0.002\right)$ to $R=0.018$ for observed reflections and $\mathrm{w} R\left(F^{2}\right)=0.045, G O F=1.08$ for 255 parameters and all 4526 reflections. The final difference map displayed no peaks of chemical significance $\left(\Delta \rho_{\max }=\right.$ $\left.0.26, \Delta \rho_{\min }-0.42 \mathrm{e} . \AA^{-3}\right)$. Absolute structure parameter $\left(\right.$ Flack $\left.^{3}\right):-0.0082(19)$

Computer programs: Bruker Instrument Service vV6.2.3, SAINT V8.37A (Bruker AXS Inc., 2015), XT, VERSION 2014/5, SHELXL2018/3 (Sheldrick, 2018).

X-ray crystallographic data have been deposited with the Cambridge Crystallographic Data Centre (CCDC) under deposition number 1978776 for 3ag and can be obtained free of charge from the Centre via its website (www.ccdc.cam.ac.uk/getstructures).

\footnotetext{
${ }^{1}$ Sheldrick, G. M. Acta Cryst. 2015, A71, 3-8.

2 Sheldrick, G. M. Acta Cryst. 2015, C71, 3-8.

${ }^{3}$ Parsons, S.; Flack, H. D.; Wagner, T. Acta Cryst. 2013, B69, 249-259.
} 
Figure 1: View on molecule of $\mathbf{3 a g}$, the displacement ellipsoids are drawn at 50\% probability level. Stereodescriprors on C2, C3, C7: S, S, S.

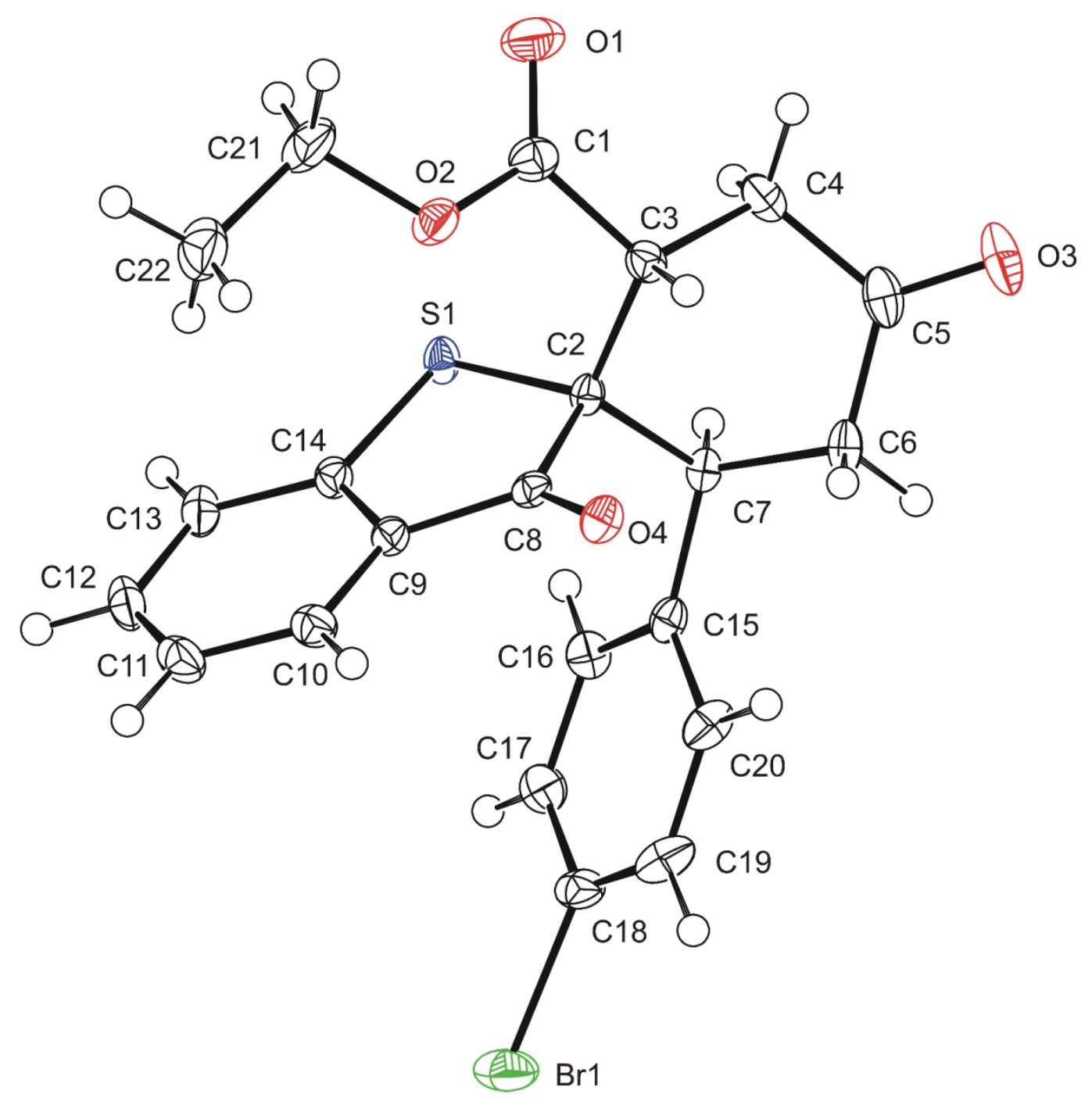

\section{Computing details}

Data collection: Bruker Instrument Service vV6.2.3; cell refinement: SAINT V8.37A (Bruker AXS Inc., 2015); data reduction: SAINT V8.37A (Bruker AXS Inc., 2015); program(s) used to solve structure: XT, VERSION 2014/5; program(s) used to refine structure:

SHELXL2018/3 (Sheldrick, 2018).

Table S4: Computing details for 3ag.

Crystal data

\begin{tabular}{|l|l|}
\hline $\mathrm{C}_{22} \mathrm{H}_{19} \mathrm{BrO}_{4} \mathrm{~S}$ & $D_{\mathrm{x}}=1.544 \mathrm{Mg} \mathrm{m}^{-3}$ \\
\hline$M_{r}=459.34$ & Mo Ka radiation, $1=0.71073 \AA$ \\
\hline
\end{tabular}




\begin{tabular}{|l|l|}
\hline Orthorhombic, $P 2_{1} 2_{1} 2_{1}$ & Cell parameters from 9845 reflections \\
\hline$a=11.0046(4) \AA$ & $\mathrm{q}=2.6-27.5^{\circ}$ \\
\hline$b=11.4721(4) \AA$ & $\mathrm{m}=2.21 \mathrm{~mm}^{-1}$ \\
\hline$c=15.6538(4) \AA$ & $T=150 \mathrm{~K}$ \\
\hline$V=1976.23(11) \AA^{3}$ & Prism, light yellow \\
\hline$Z=4$ & $0.30 \times 0.16 \times 0.10 \mathrm{~mm}$ \\
\hline$F(000)=936$ & \\
\hline
\end{tabular}

\section{Data collection}

\begin{tabular}{|l|l|}
\hline $\begin{array}{l}\text { Bruker D8 VENTURE Kappa Duo } \\
\text { PHOTON 100 CMOS } \\
\text { diffractometer }\end{array}$ & 4526 independent reflections \\
\hline $\begin{array}{l}\text { Radiation source: ImS micro-focus } \\
\text { sealed tube }\end{array}$ & 4374 reflections with $I>2 \mathrm{~s}(I)$ \\
\hline $\begin{array}{l}\text { Quazar Mo multilayer optic } \\
\text { monochromator }\end{array}$ & $R_{\mathrm{int}}=0.025$ \\
\hline f and w scans & $\mathrm{q}_{\max }=27.5^{\circ}, \mathrm{q}_{\min }=2.2^{\circ}$ \\
\hline $\begin{array}{l}\text { Absorption correction: numerical Mu } \\
\text { From Formula } \\
\text { SADABS2016/2 - Bruker AXS area } \\
\text { detector scaling and absorption } \\
\text { correction }\end{array}$ & $h=-14 \circledast 14$ \\
\hline$T_{\min }=0.647, T_{\max }=0.869$ & $k=-14 \circledast 14$ \\
\hline 28071 measured reflections & $l=-20 ® 20$ \\
\hline
\end{tabular}

\section{Refinement}

\begin{tabular}{|l|l|}
\hline Refinement on $F^{2}$ & H-atom parameters constrained \\
\hline Least-squares matrix: full & $\begin{array}{l}w=1 /\left[\mathrm{s}^{2}\left(F_{\mathrm{o}}^{2}\right)+(0.020 P)^{2}+0.5626 P\right] \\
\text { where } P=\left(F_{\mathrm{o}}{ }^{2}+2 F_{\mathrm{c}}{ }^{2}\right) / 3\end{array}$ \\
\hline
\end{tabular}




\begin{tabular}{|l|l|}
\hline$R\left[F^{2}>2 \mathrm{~s}\left(F^{2}\right)\right]=0.018$ & $(\mathrm{D} / \mathrm{s})_{\max }=0.002$ \\
\hline$w R\left(F^{2}\right)=0.045$ & $\mathrm{D} \rho_{\max }=0.26 \mathrm{e} \AA^{-3}$ \\
\hline$S=1.08$ & $\mathrm{D} \rho_{\min }=-0.42 \mathrm{e}^{-3}$ \\
\hline 4526 reflections & $\begin{array}{l}\text { Extinction correction: } \text { SHELXL2018/3 } \\
(\text { Sheldrick } 2018), \\
\mathrm{Fc}^{*}=\mathrm{kFc}\left[1+0.001 \mathrm{xFc}^{2} \mathrm{1}^{3} / \mathrm{sin}(2 \mathrm{q})\right]^{-1 / 4}\end{array}$ \\
\hline 255 parameters & Extinction coefficient: $0.0088(6)$ \\
\hline 0 restraints & $\begin{array}{l}\text { Absolute structure: Flack x determined } \\
\text { using } 1841 \text { quotients }[(\mathrm{I}+)-(\mathrm{I}-)] /[(\mathrm{I}+)+(\mathrm{I}-\end{array}$ \\
\hline $\begin{array}{l}\text { Primary atom site location: structure- } \\
\text { invariant direct methods }\end{array}$ & $\begin{array}{l}\text { Absolute structure parameter: }-0.0082 \\
(19)\end{array}$ \\
\hline $\begin{array}{l}\text { Hydrogen site location: inferred from } \\
\text { neighbouring sites }\end{array}$ & \\
\hline
\end{tabular}

\section{Special details}

Geometry. All esds (except the esd in the dihedral angle between two 1.s. planes) are estimated using the full covariance matrix. The cell esds are taken into account individually in the estimation of esds in distances, angles and torsion angles; correlations between esds in cell parameters are only used when they are defined by crystal symmetry. An approximate (isotropic) treatment of cell esds is used for estimating esds involving l.s. planes. 


\section{Copies of NMR spectra}

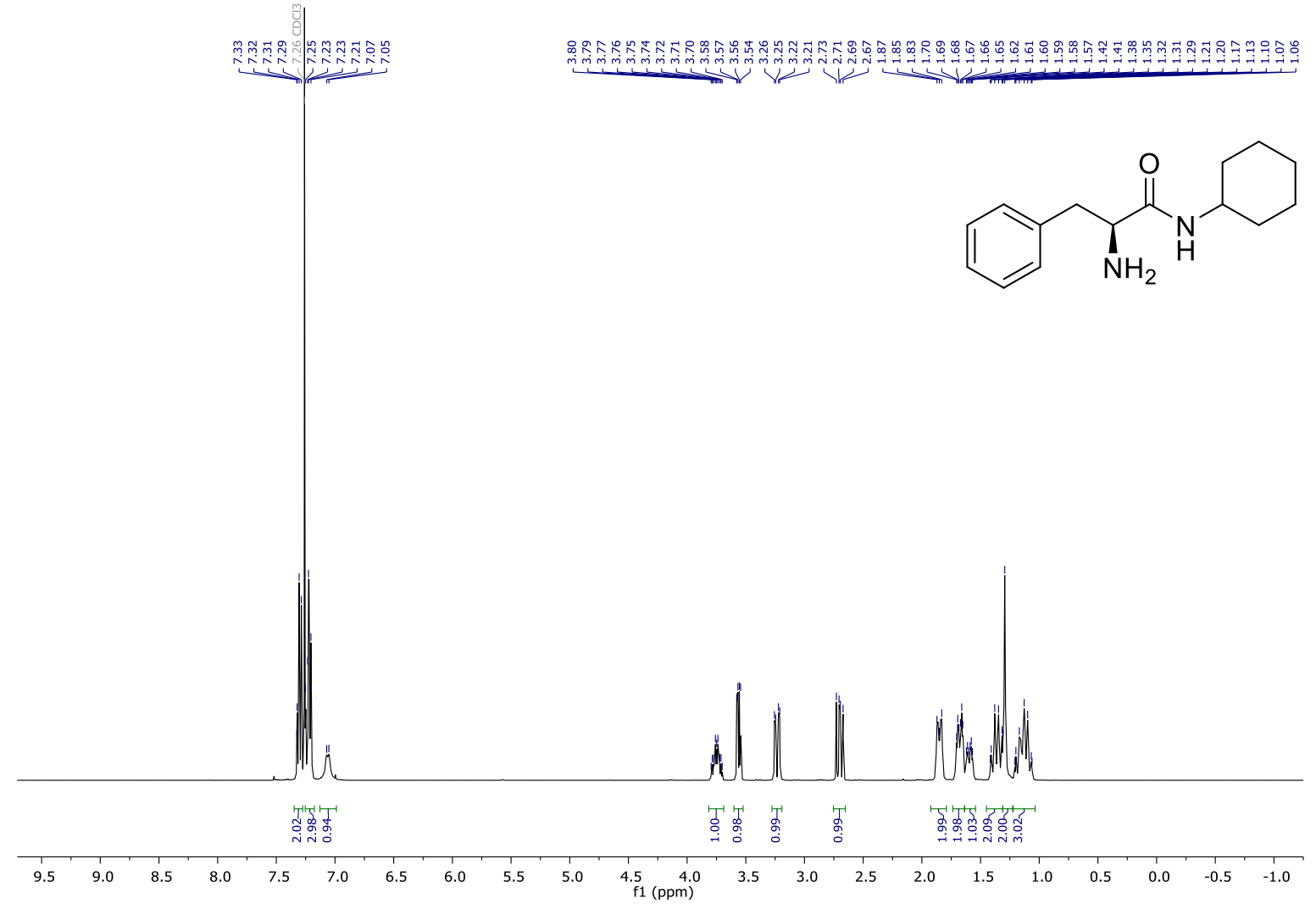

$400 \mathrm{MHz}{ }^{1} \mathrm{H} \mathrm{NMR}$ of $\mathbf{I V}^{6}$ in $\mathrm{CDCl}_{3}$.

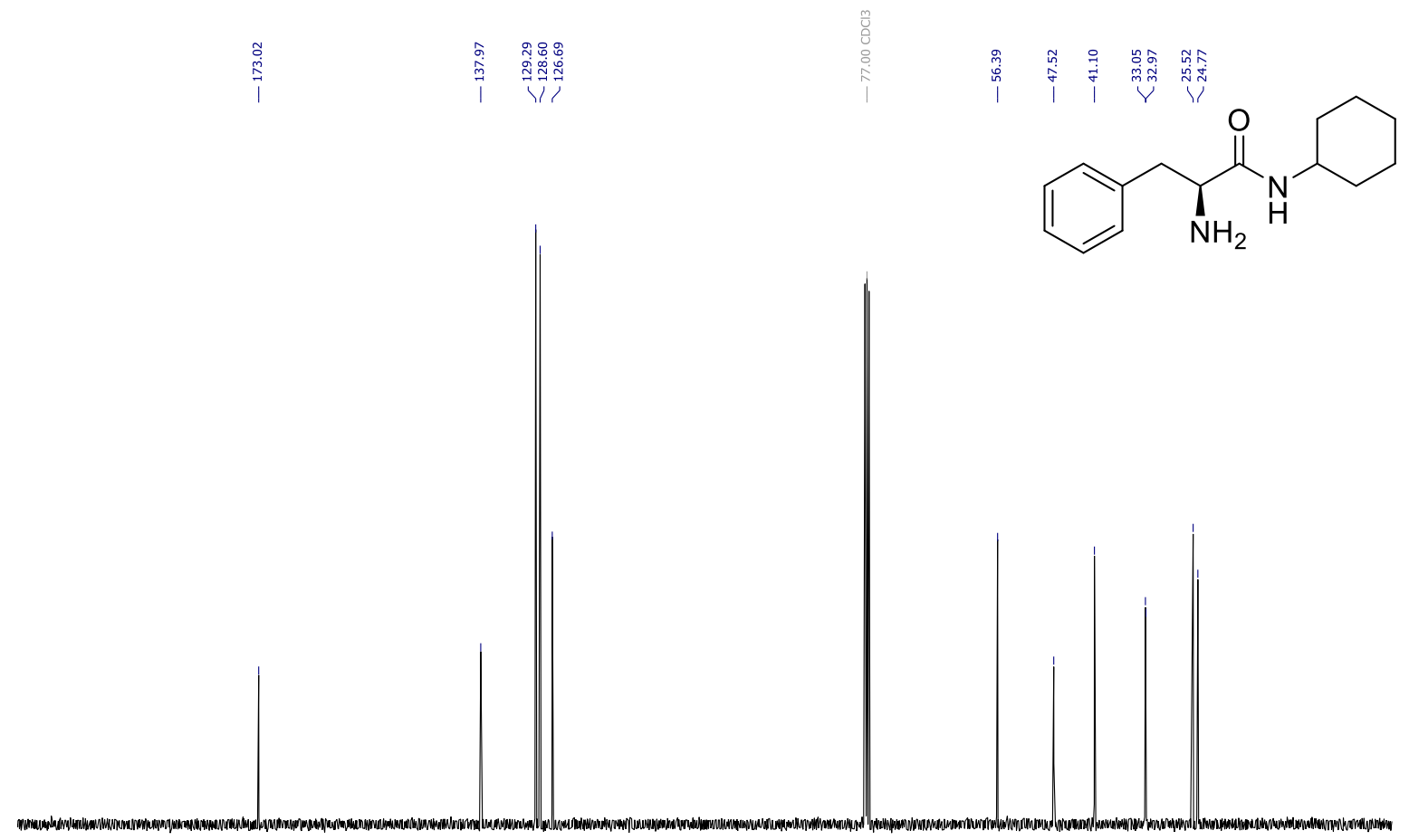

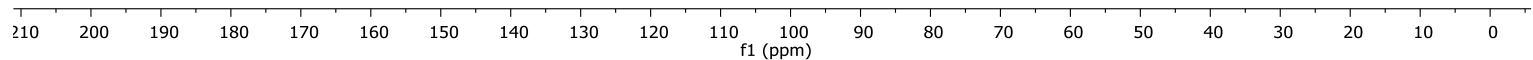
$101 \mathrm{MHz}^{13} \mathrm{C}$ NMR of $\mathbf{I V}^{`}$ in $\mathrm{CDCl}_{3}$. 

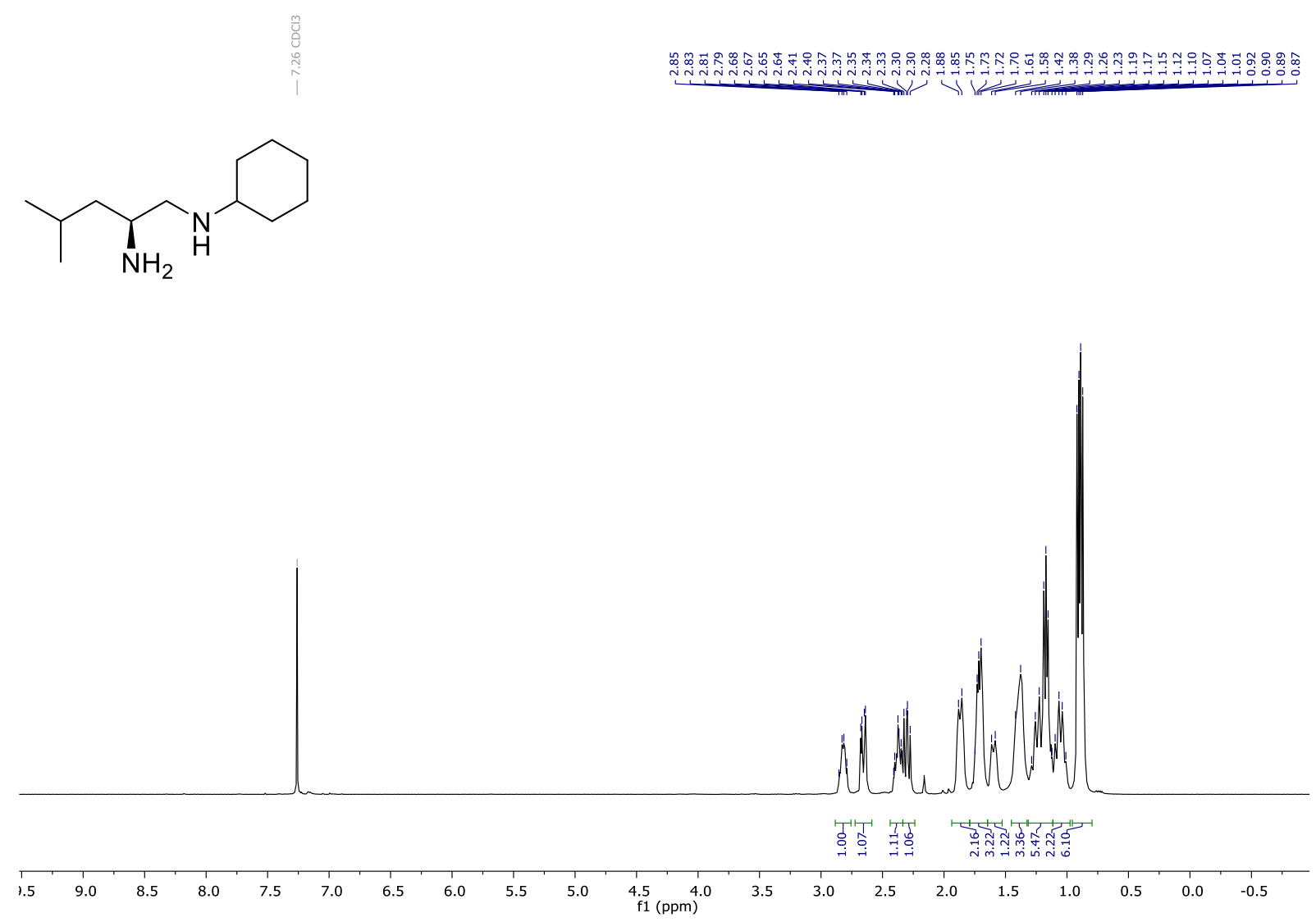

$400 \mathrm{MHz}{ }^{1} \mathrm{H}$ NMR of $\mathbf{V}$ in $\mathrm{CDCl}_{3}$.<smiles>CC(C)C[C@H](N)CNC1CCCCC1</smiles>

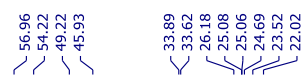

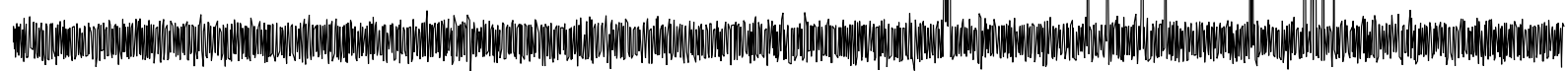

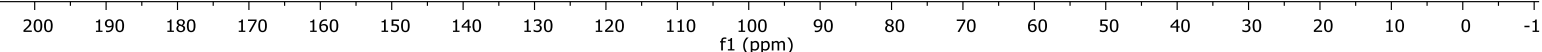

$101 \mathrm{MHz}{ }^{13} \mathrm{C} \mathrm{NMR}$ of $\mathbf{V}$ in $\mathrm{CDCl}_{3}$. 
<smiles>C=CCOC(=O)/C=C1\Sc2ccccc2C1=O</smiles>

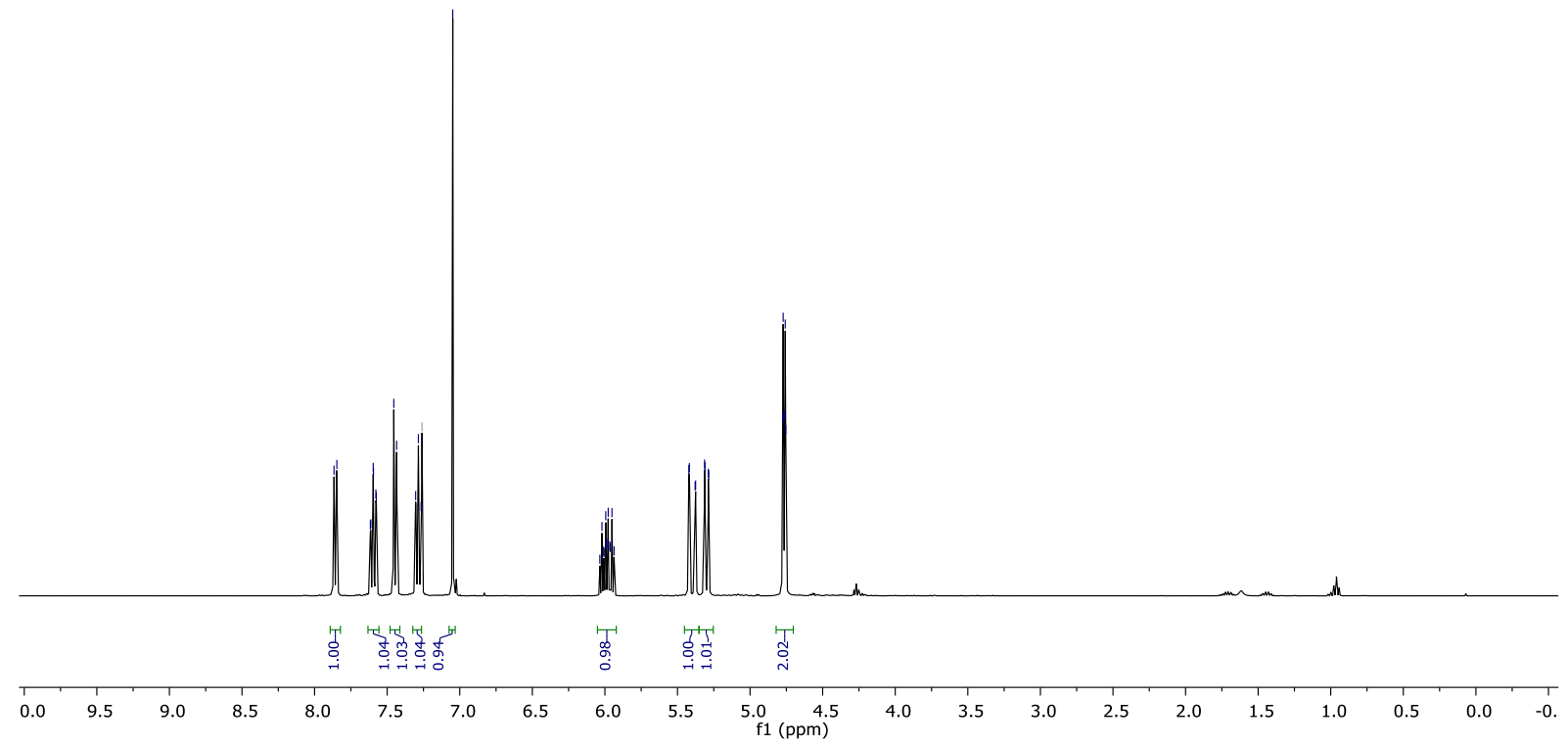

$400 \mathrm{MHz}{ }^{1} \mathrm{H}$ NMR of $\mathbf{1 f}$ in $\mathrm{CDCl}_{3}$.
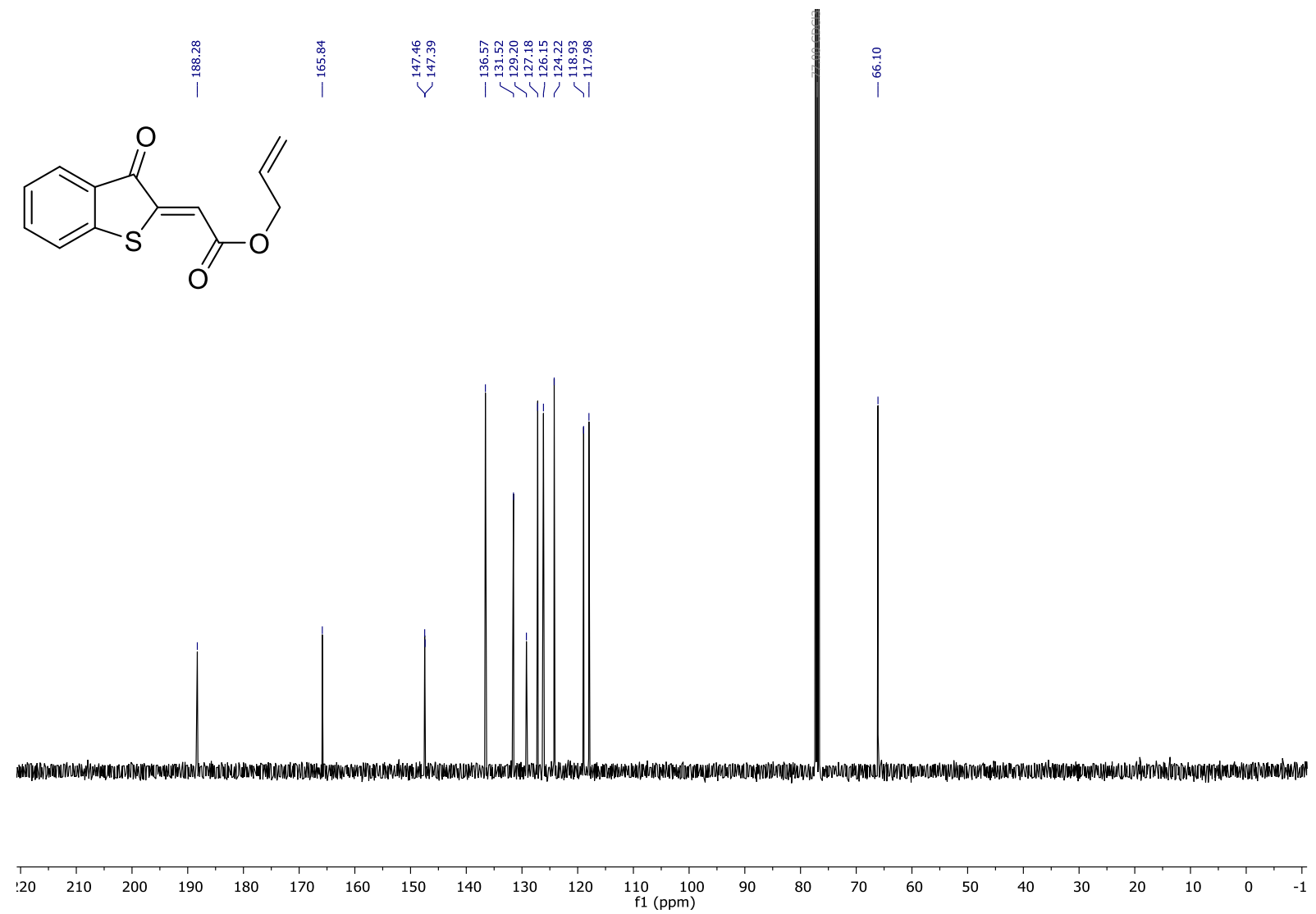

$101 \mathrm{MHz}{ }^{13} \mathrm{C}$ NMR of $\mathbf{1 f}$ in $\mathrm{CDCl}_{3}$. 

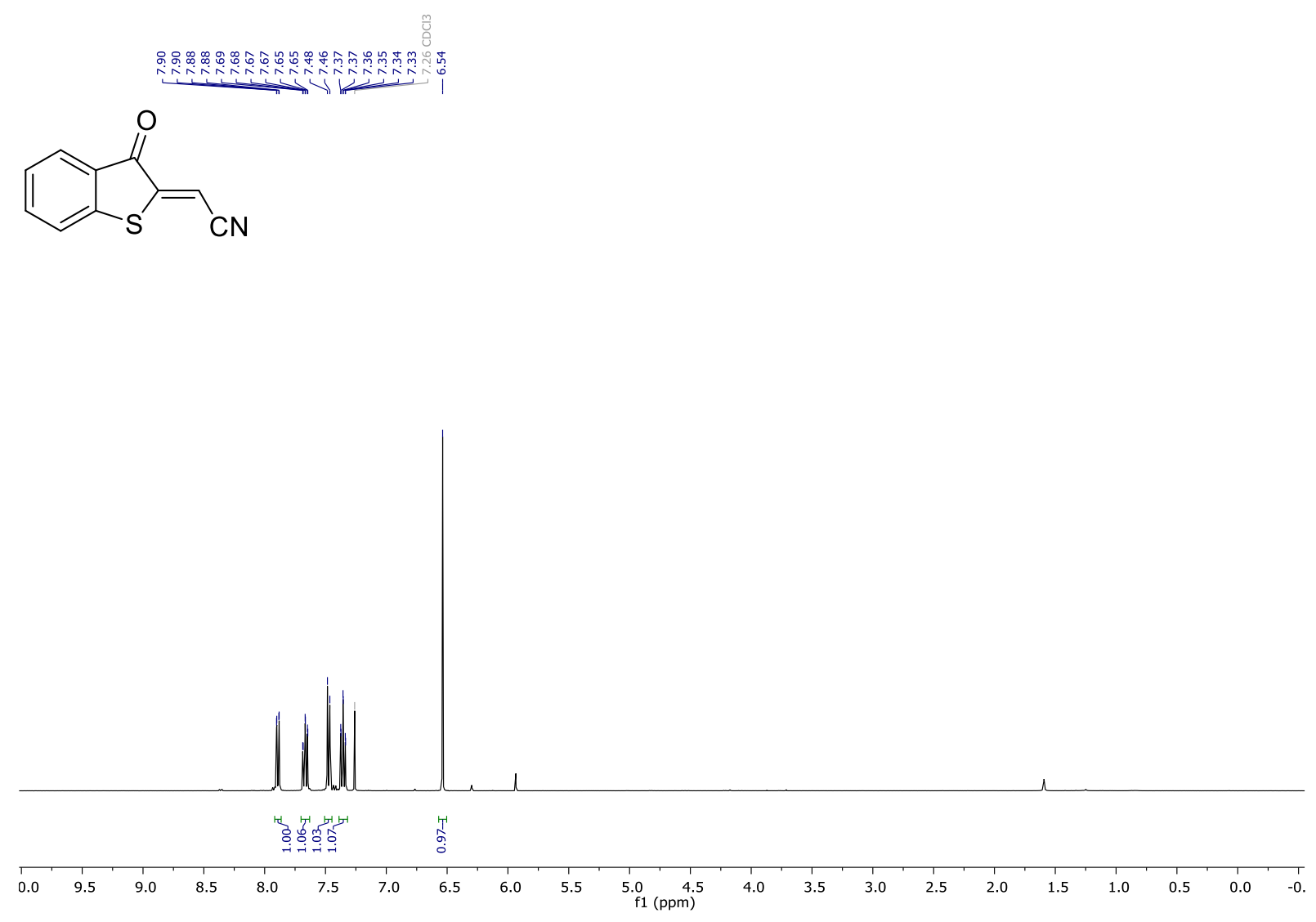

$400 \mathrm{MHz}{ }^{1} \mathrm{H}$ NMR of $\mathbf{1 g}$ in $\mathrm{CDCl}_{3}$.<smiles>N#C/C=C1\Sc2ccccc2C1=O</smiles>

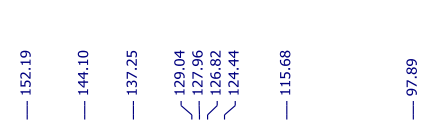

$$
\text { CN }
$$

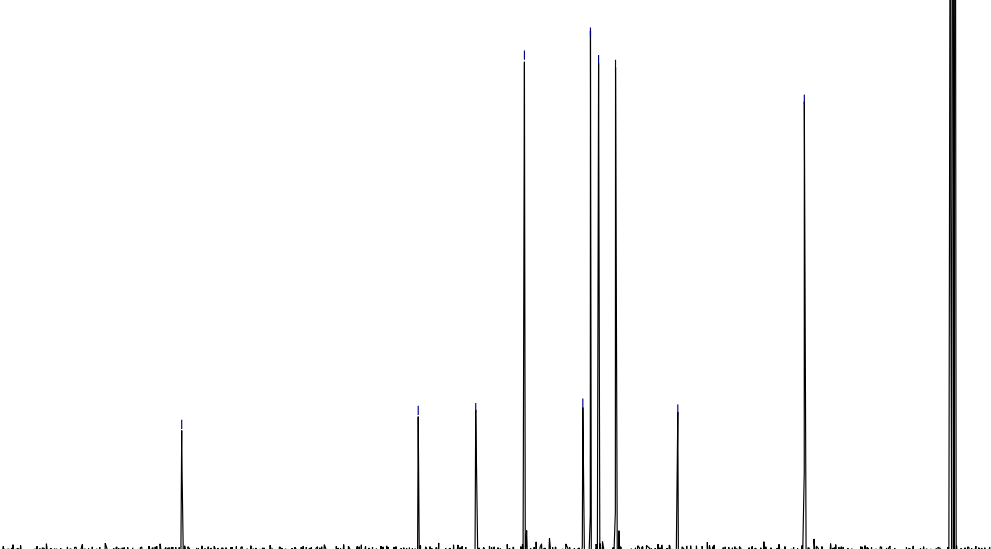

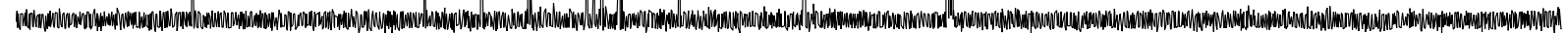

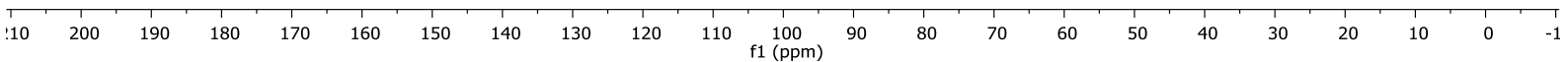

$101 \mathrm{MHz}{ }^{13} \mathrm{C}$ NMR of $1 \mathrm{~g}$ in $\mathrm{CDCl}_{3}$. 
<smiles>CCOC=C1Sc2ccc(Br)cc2C1=O</smiles>

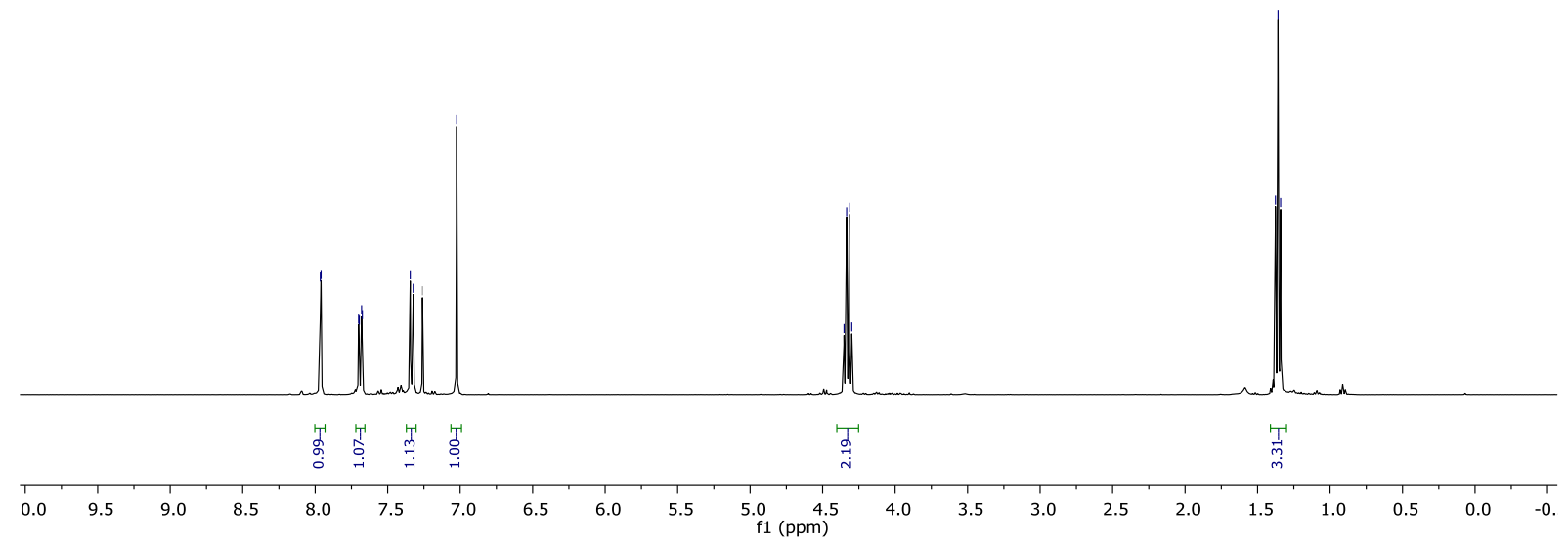

$400 \mathrm{MHz}{ }^{1} \mathrm{H}$ NMR of $\mathbf{1 h}$ in $\mathrm{CDCl}_{3}$.<smiles>CCOC=C1Sc2ccc(Br)cc2C1=O</smiles>

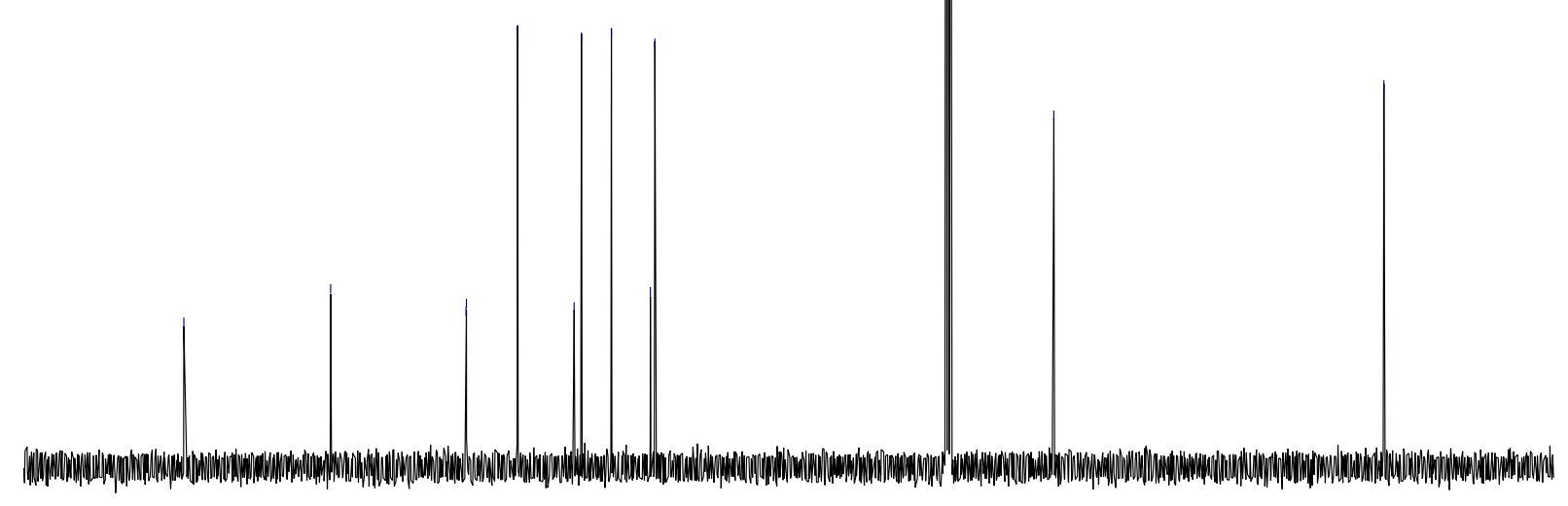

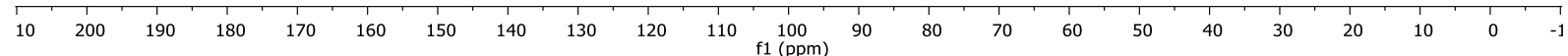

$101 \mathrm{MHz}{ }^{13} \mathrm{C}$ NMR of $\mathbf{1 h}$ in $\mathrm{CDCl}_{3}$. 

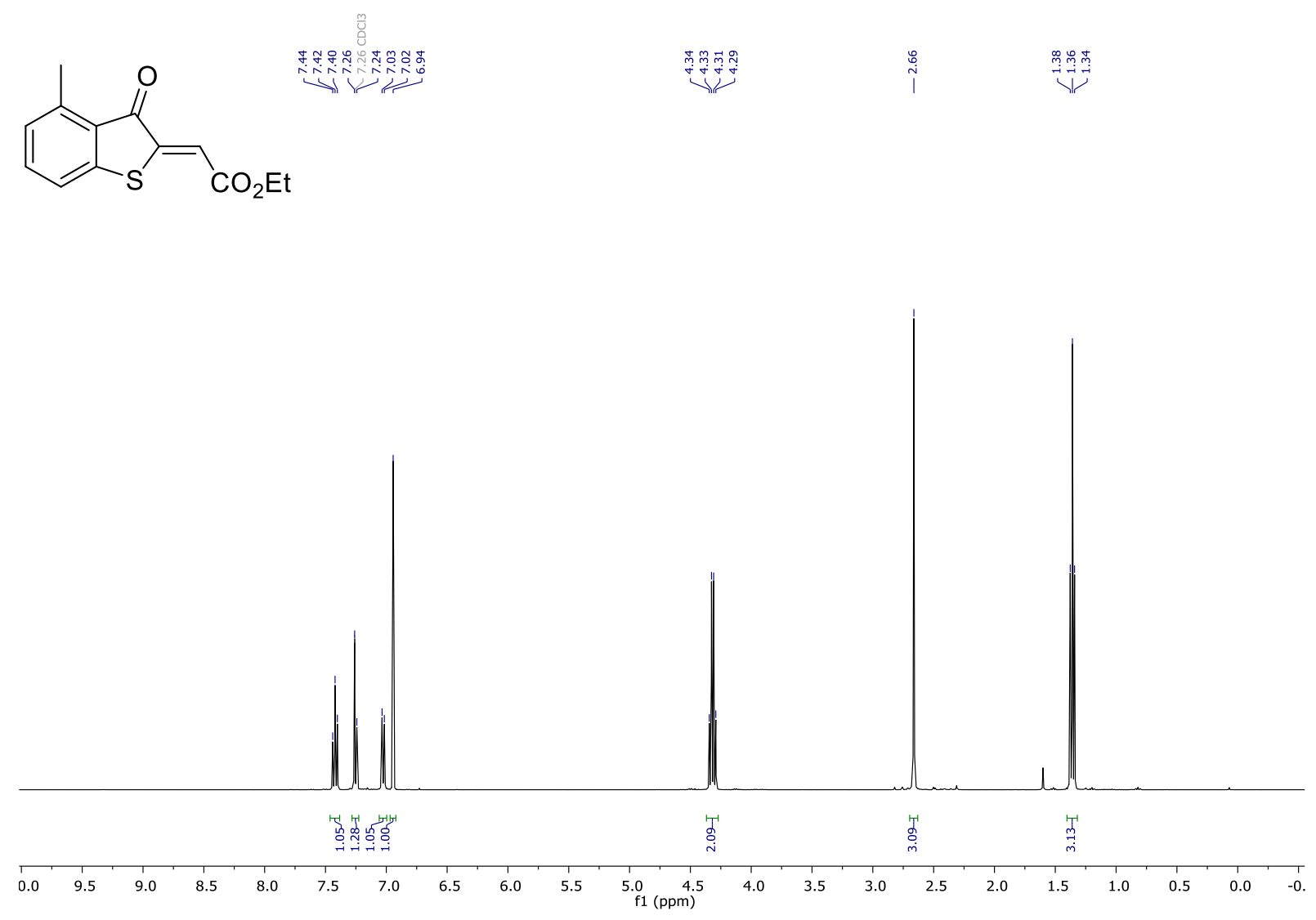

$400 \mathrm{MHz}{ }^{1} \mathrm{H}$ NMR of $\mathbf{1} \mathbf{j}$ in $\mathrm{CDCl}_{3}$.
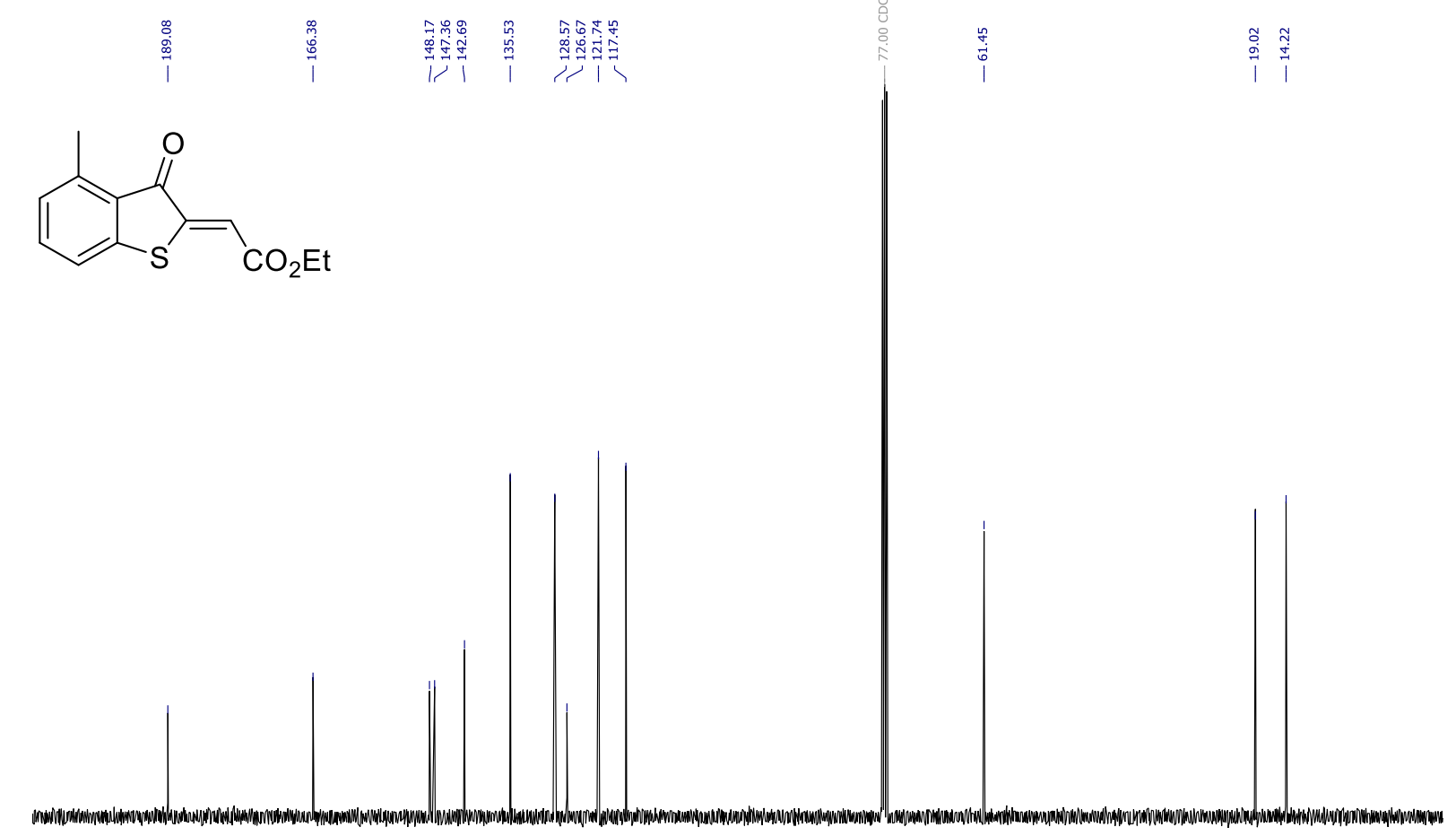

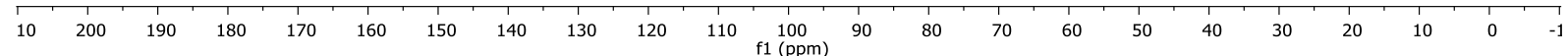

$101 \mathrm{MHz}{ }^{13} \mathrm{C}$ NMR of $\mathbf{1} \mathbf{j}$ in $\mathrm{CDCl}_{3}$. 


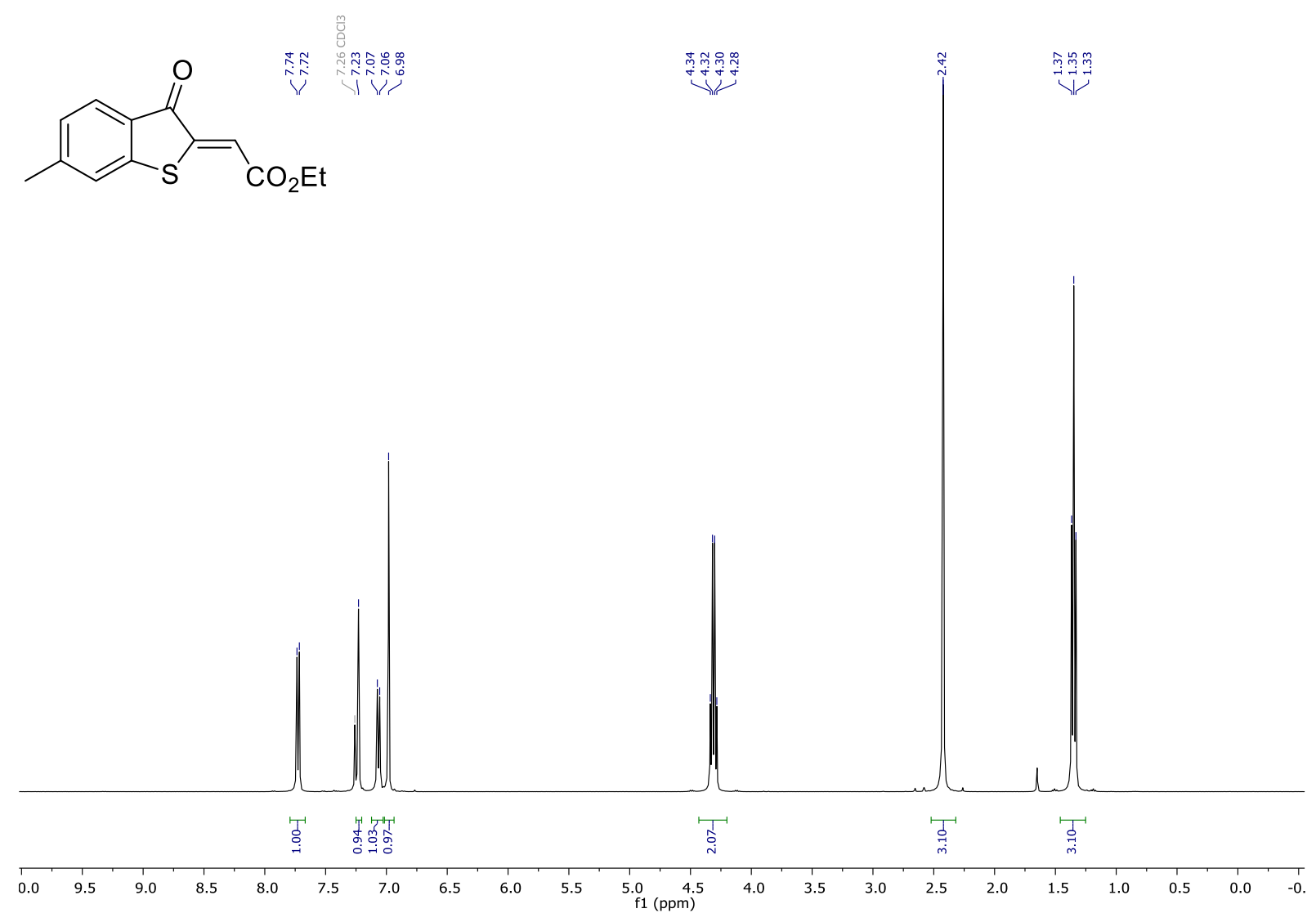

$400 \mathrm{MHz}{ }^{1} \mathrm{H}$ NMR of $\mathbf{1} \mathbf{k}$ in $\mathrm{CDCl}_{3}$.
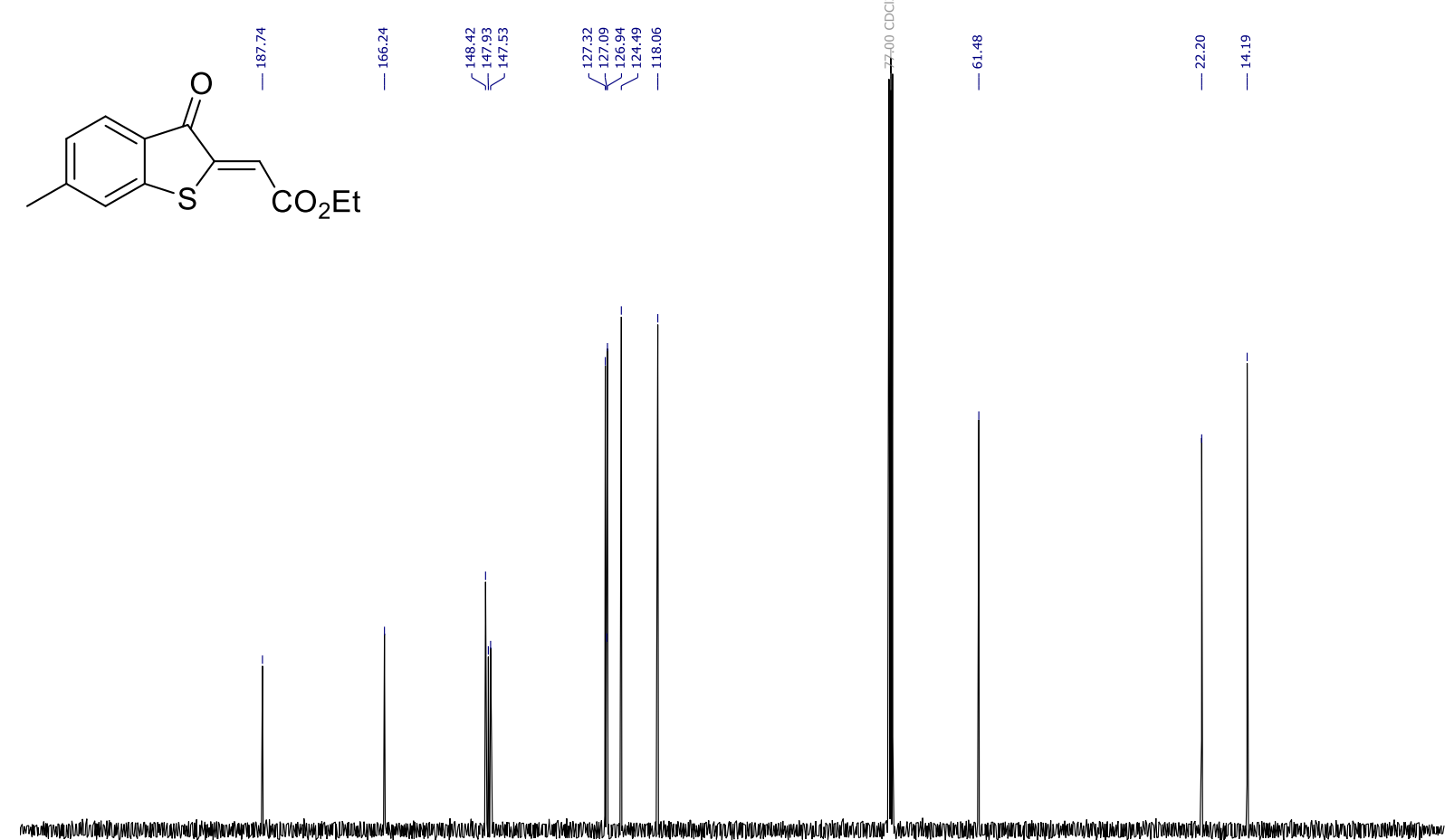

\begin{tabular}{llllllllllllllllllllllllllll}
\hline 30 & 220 & 210 & 200 & 190 & 180 & 170 & 160 & 150 & 140 & 130 & 120 & 110 & 100 & 90 & 80 & 70 & 60 & 50 & 40 & 30 & 20 & 10 & 0 & -10 & -2
\end{tabular}

$101 \mathrm{MHz}{ }^{13} \mathrm{C}$ NMR of $\mathbf{1 k}$ in $\mathrm{CDCl}_{3}$. 


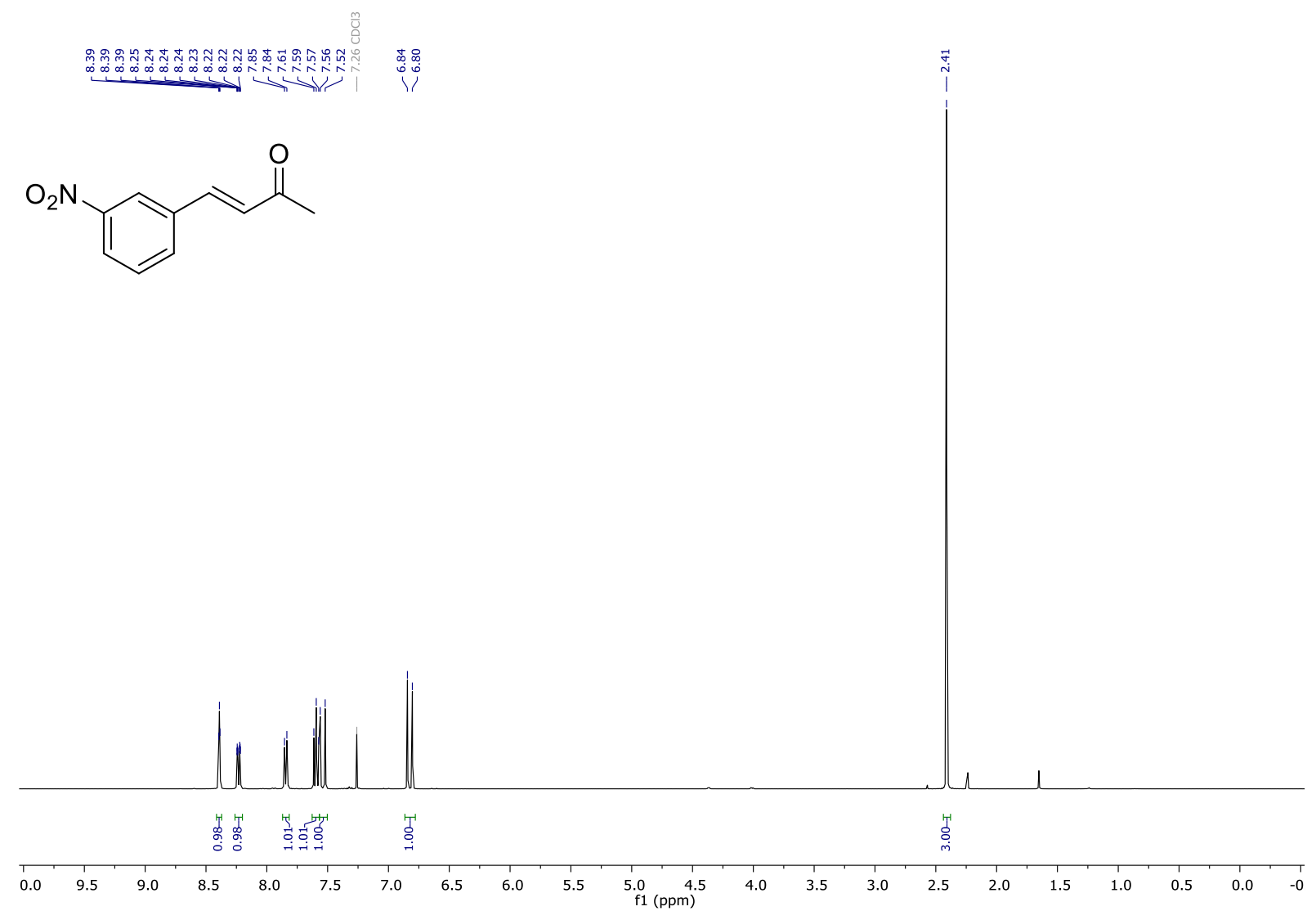

$400 \mathrm{MHz}{ }^{1} \mathrm{H}$ NMR of $2 \mathbf{d}$ in $\mathrm{CDCl}_{3}$.

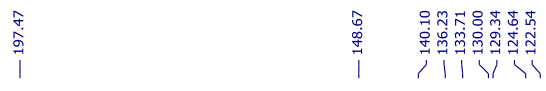

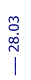<smiles>CC(=O)/C=C/c1cccc([N+](=O)[O-])c1</smiles>
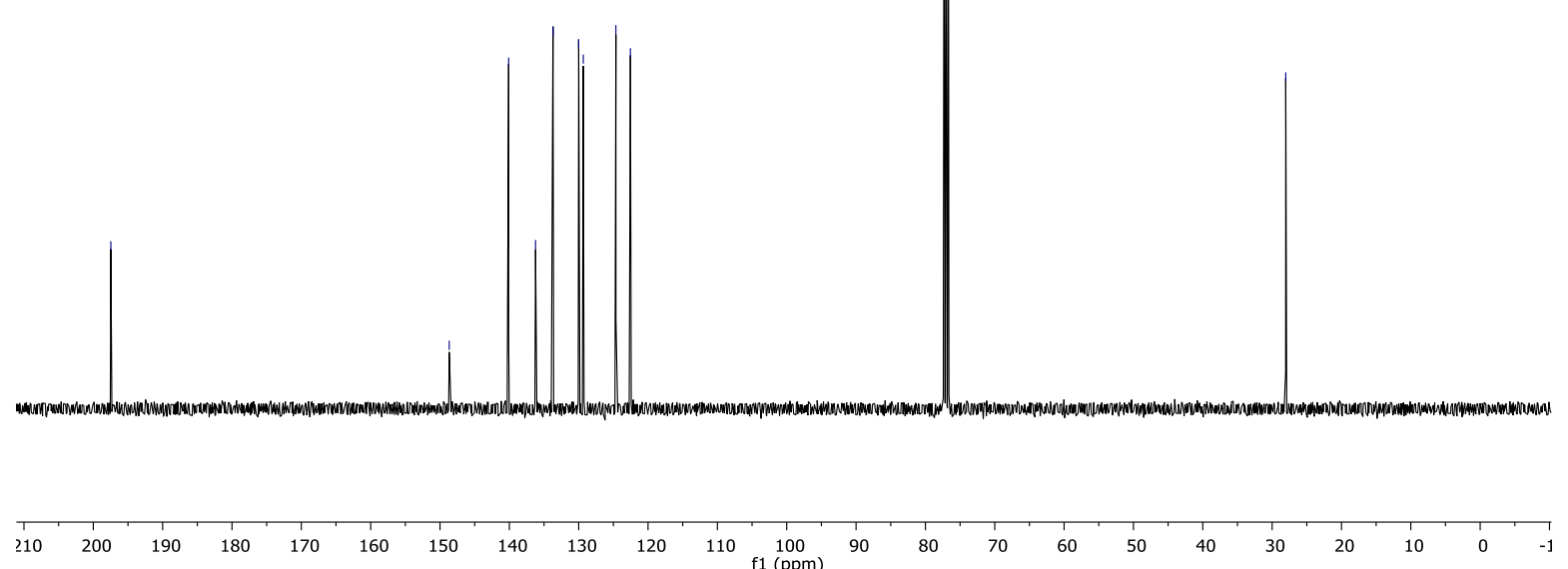

$101 \mathrm{MHz}{ }^{13} \mathrm{C}$ NMR of $2 d$ in $\mathrm{CDCl}_{3}$. 
<smiles>CCOC(=O)[C@@]12CC(=O)CC(c3ccccc3)[C@]1(C(=O)OCC)Sc1ccccc12</smiles>

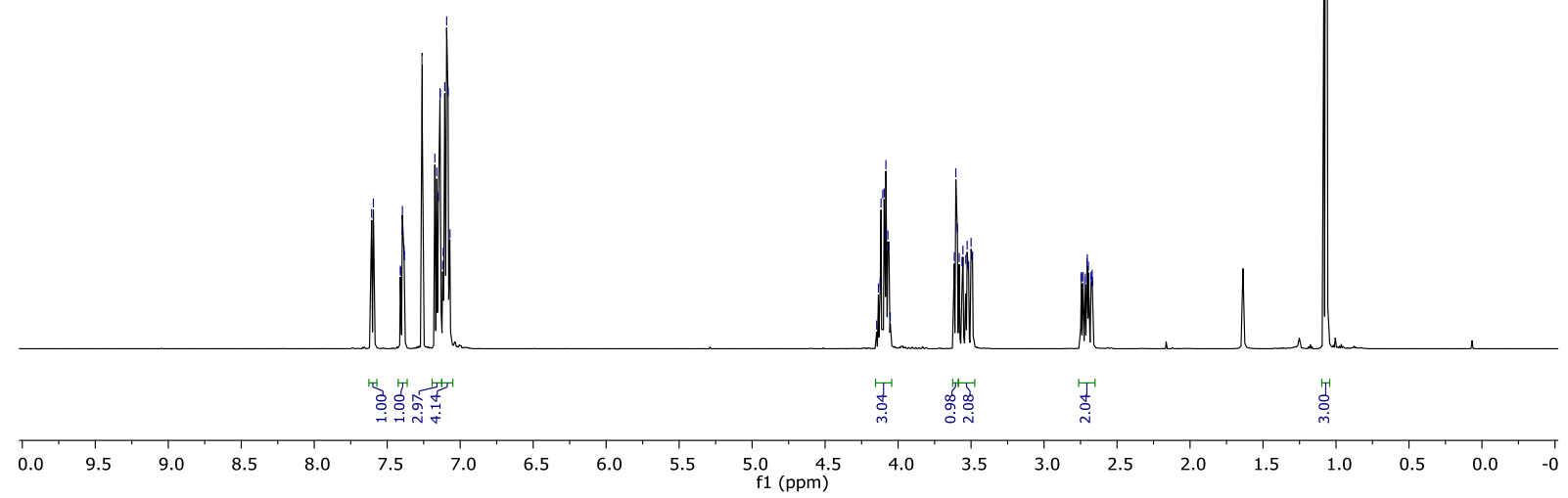

$600 \mathrm{MHz}{ }^{1} \mathrm{H}$ NMR of $\mathbf{3 a a}$ in $\mathrm{CDCl}_{3}$.

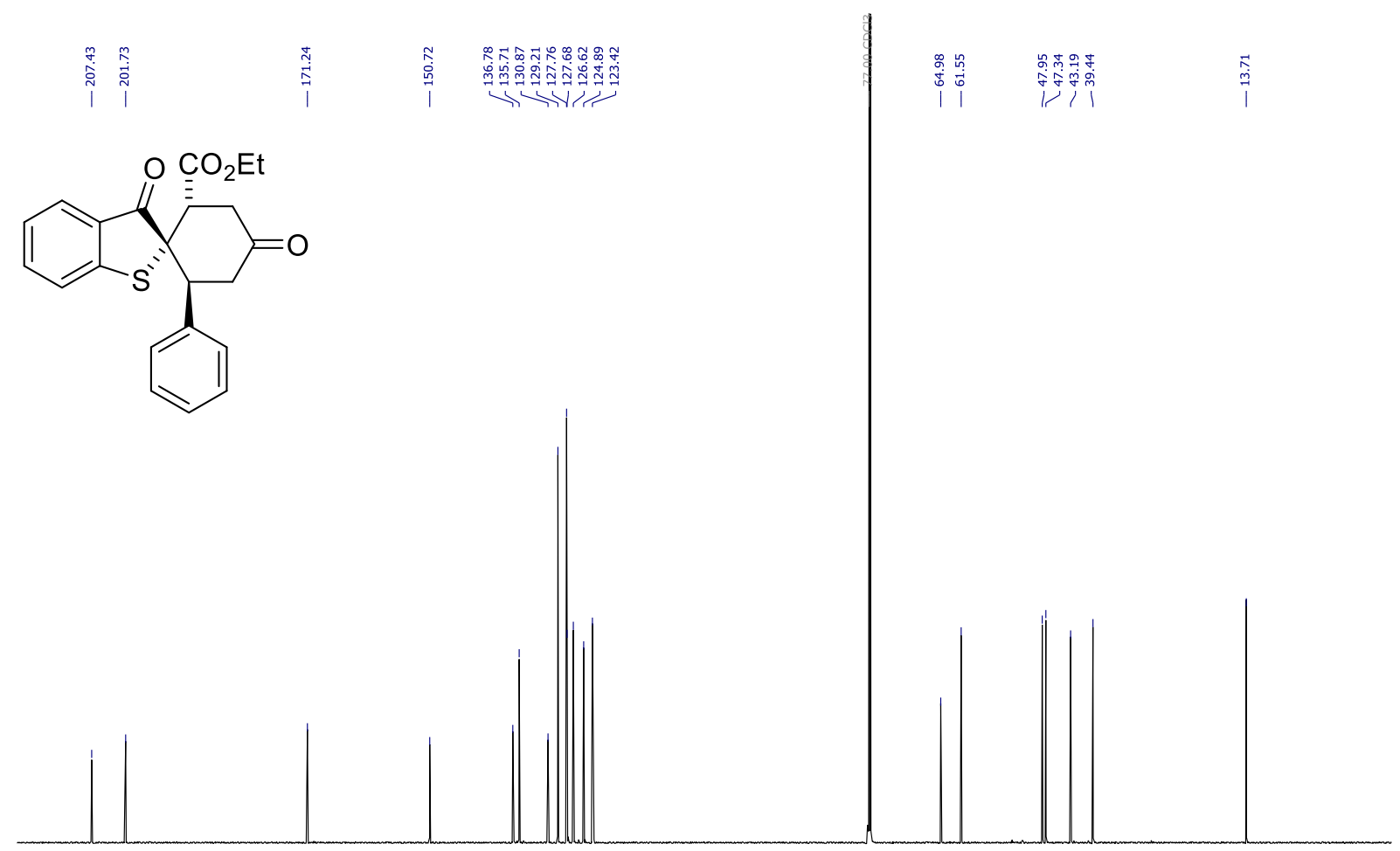

$\begin{array}{lllllllllllllllllllllll}1 & 200 & 190 & 180 & 170 & 160 & 150 & 140 & 130 & 120 & \begin{array}{c}110 \\ \mathrm{f} 1(\mathrm{ppm})\end{array} & 90 & 80 & 70 & 60 & 50 & 40 & 30 & 20 & 10 & 0 & -1\end{array}$

$151 \mathrm{MHz}{ }^{13} \mathrm{C}$ NMR of $\mathbf{3 a a}$ in $\mathrm{CDCl}_{3}$. 


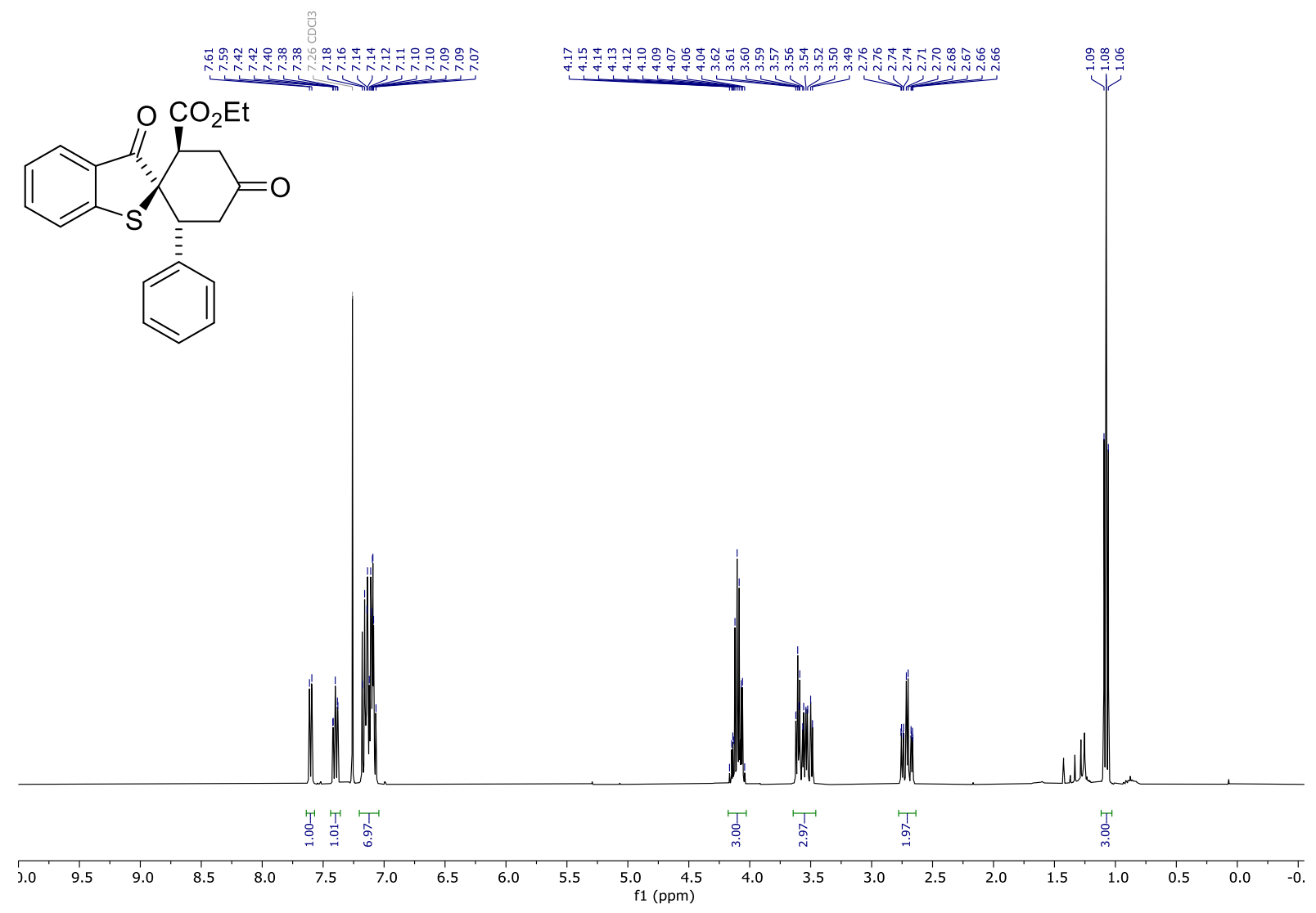

$600 \mathrm{MHz}{ }^{1} \mathrm{H} \mathrm{NMR}$ of ent-3aa in $\mathrm{CDCl}_{3}$.
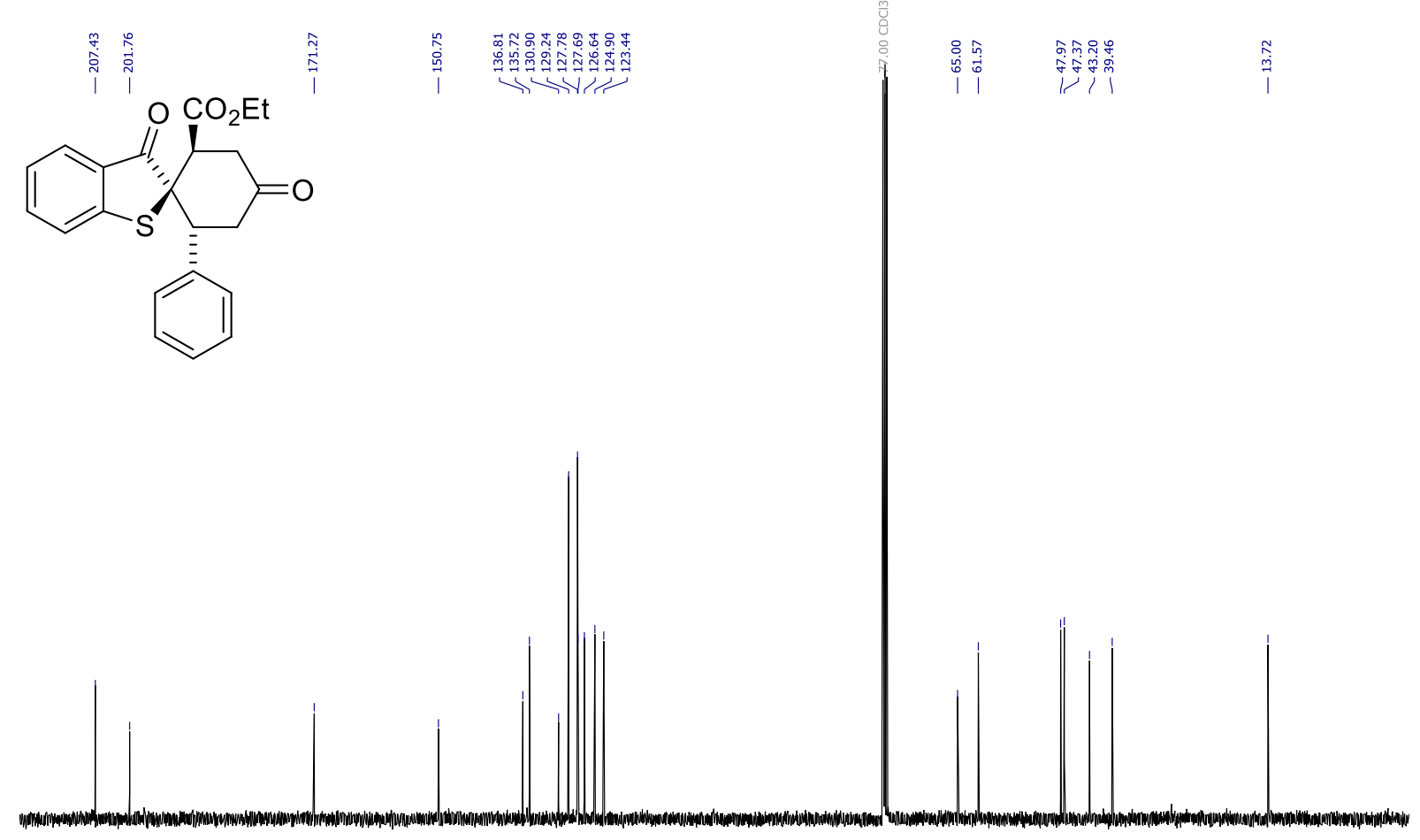

\begin{tabular}{llllllllllllllllllllll}
\hline 210 & 200 & 190 & 180 & 170 & 160 & 150 & 140 & 130 & 120 & $\begin{array}{c}110 \\
\mathrm{f} 1(\mathrm{ppm})\end{array}$ & 90 & 80 & 70 & 60 & 50 & 40 & 30 & 20 & 10 & 0 & 10
\end{tabular}

$151 \mathrm{MHz}{ }^{13} \mathrm{C}$ NMR of ent-3aa in $\mathrm{CDCl}_{3}$. 


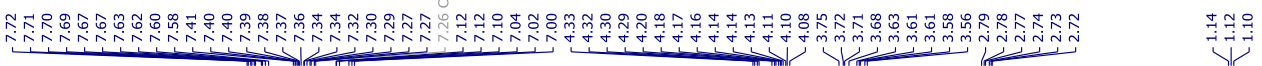<smiles>CCOC(=O)C12CC(=O)CC1(c1ccc3ccccc3c1)C(=O)c1ccccc1S2</smiles>
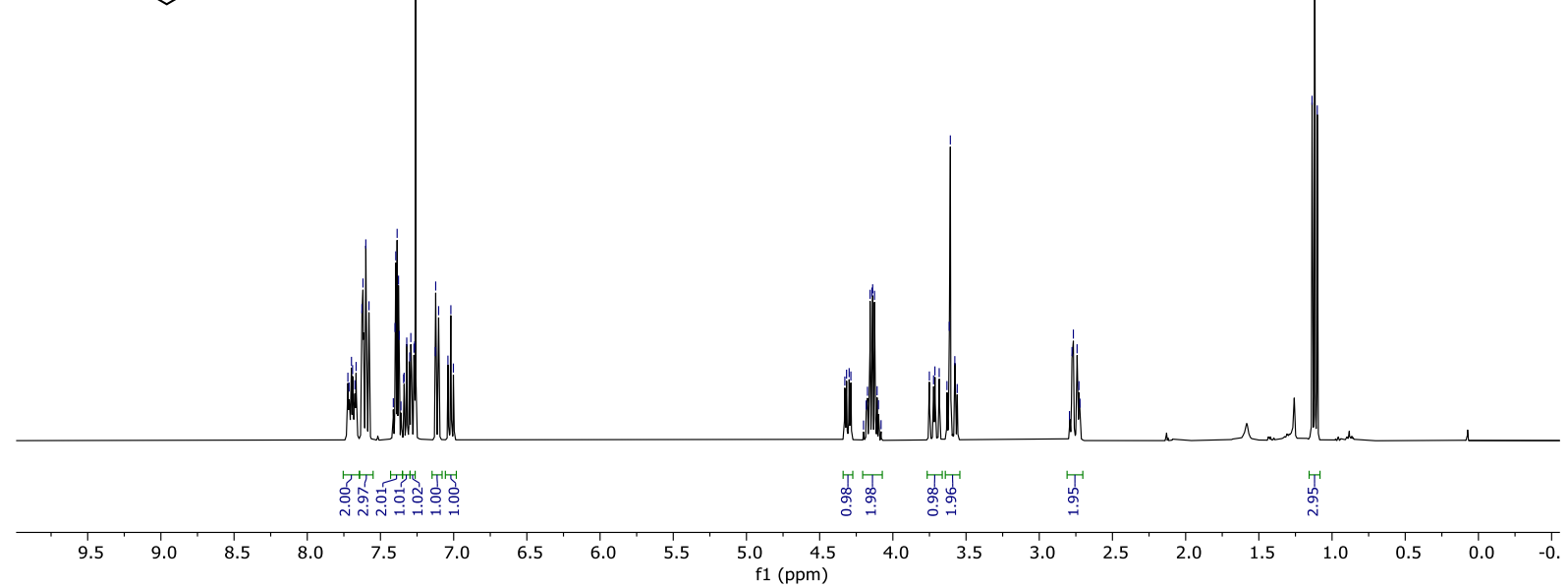

$400 \mathrm{MHz}{ }^{1} \mathrm{H}$ NMR of $\mathbf{3 a b}$ in $\mathrm{CDCl}_{3}$.

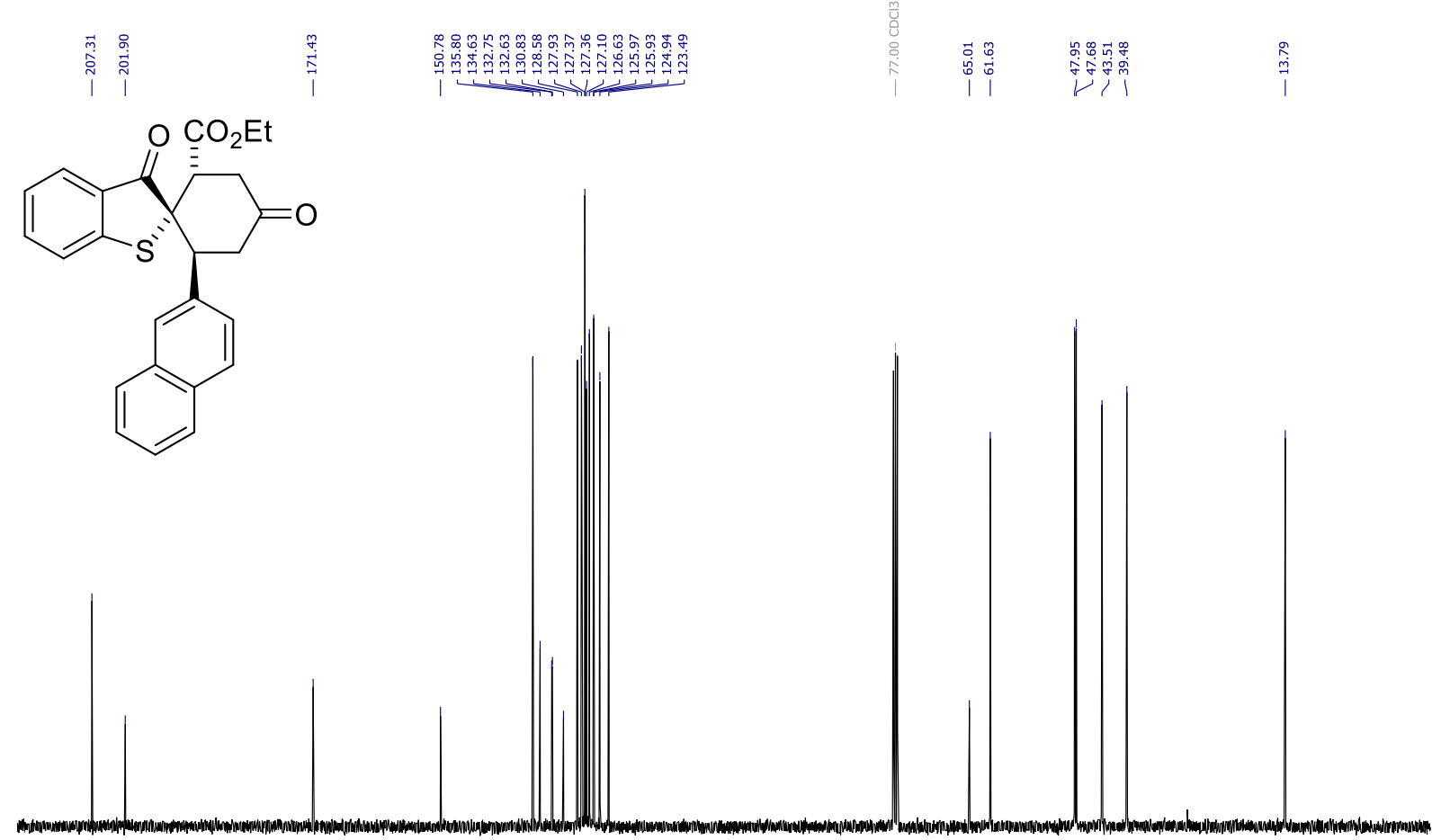

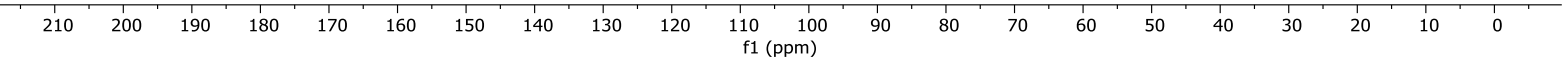

$101 \mathrm{MHz}{ }^{13} \mathrm{C}$ NMR of $\mathbf{3 a b}$ in $\mathrm{CDCl}_{3}$. 


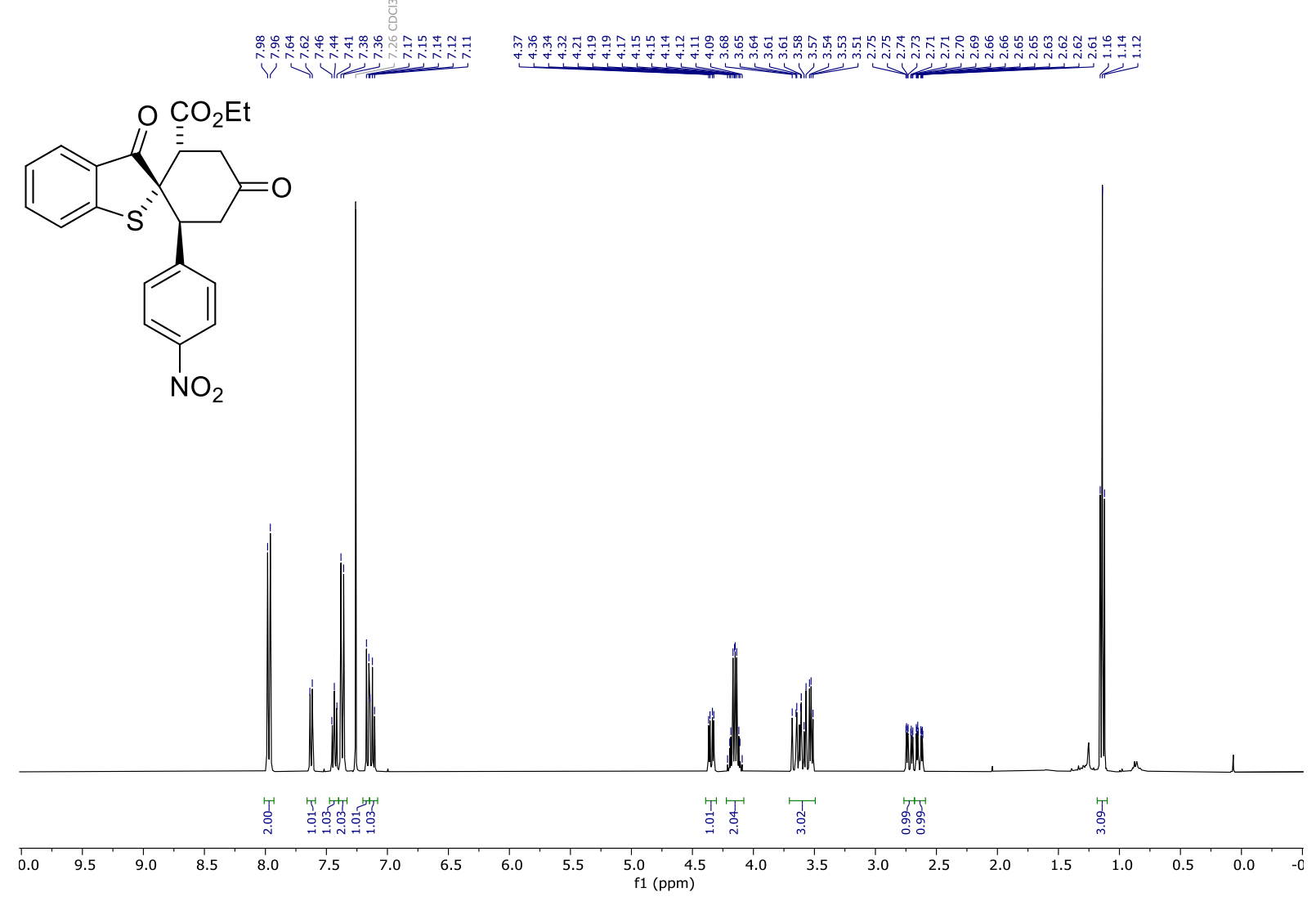

$400 \mathrm{MHz}{ }^{1} \mathrm{H}$ NMR of $\mathbf{3 a c}$ in $\mathrm{CDCl}_{3}$.

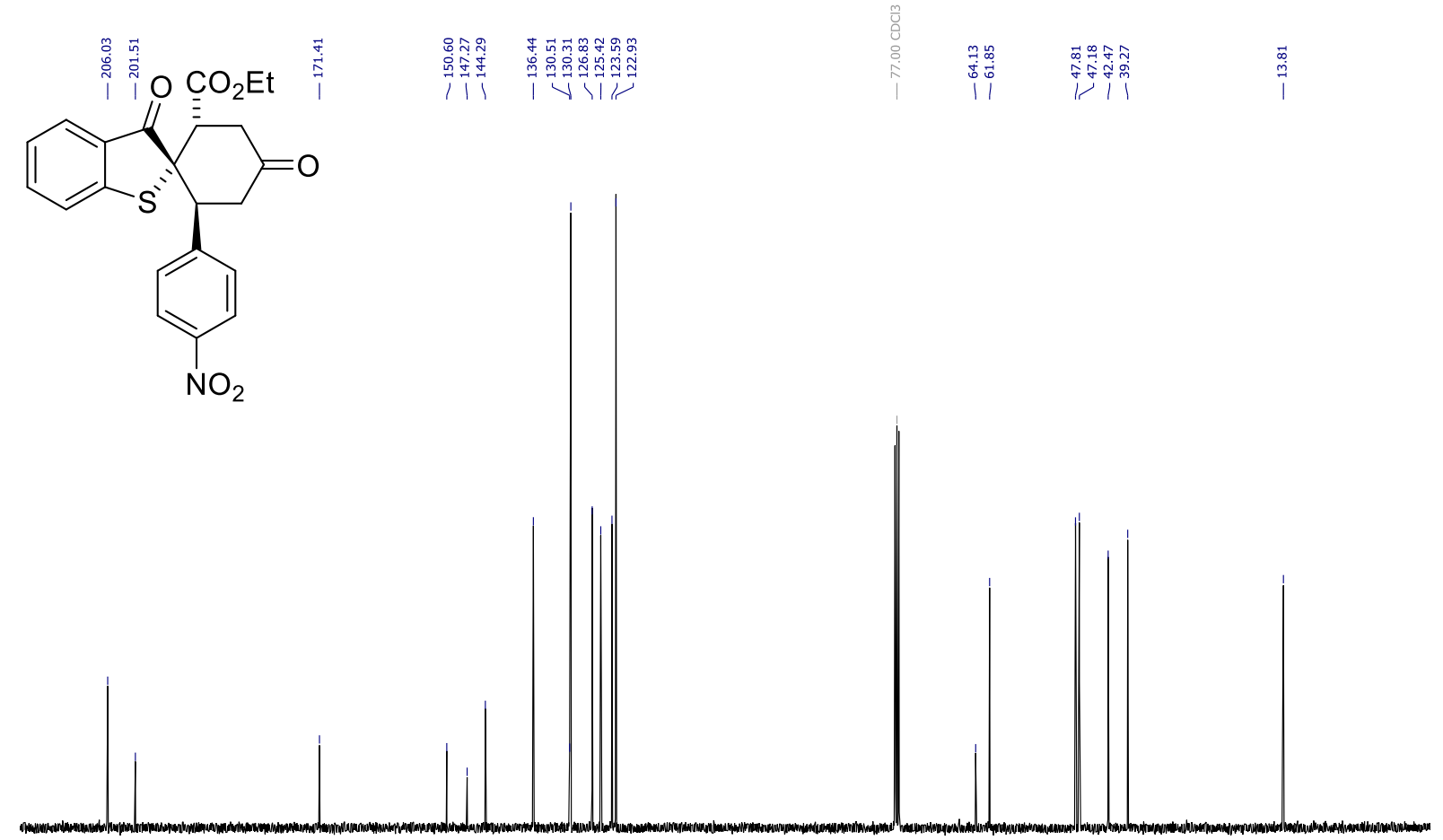

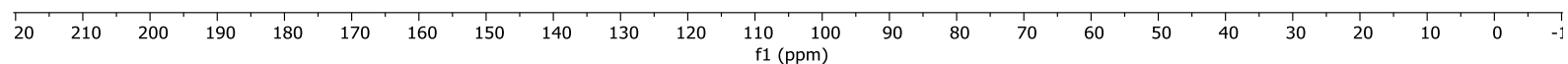

$101 \mathrm{MHz}{ }^{13} \mathrm{C}$ NMR of $\mathbf{3 a c}$ in $\mathrm{CDCl}_{3}$. 


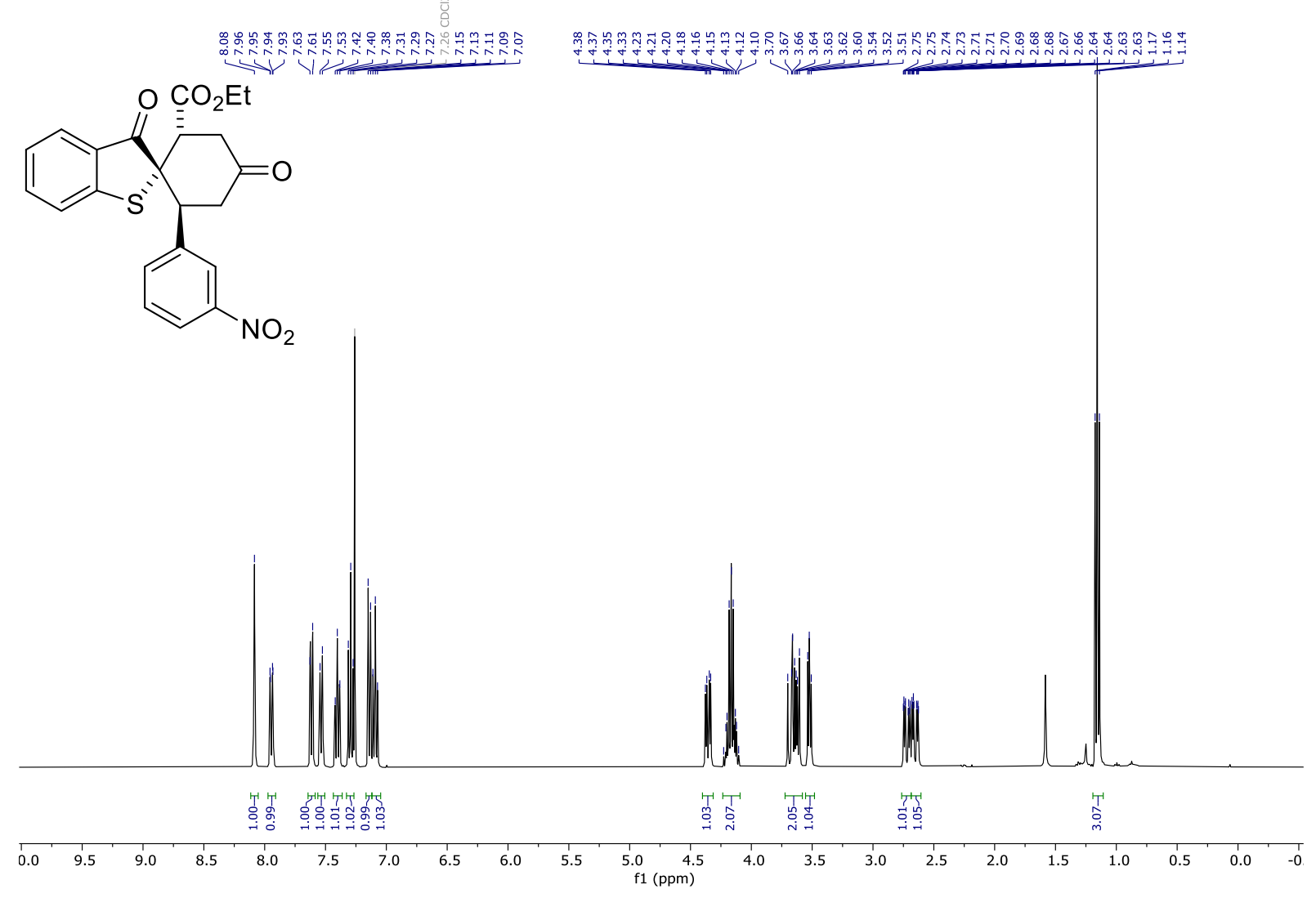

$400 \mathrm{MHz}{ }^{1} \mathrm{H}$ NMR of $\mathbf{3 a d}$ in $\mathrm{CDCl}_{3}$.

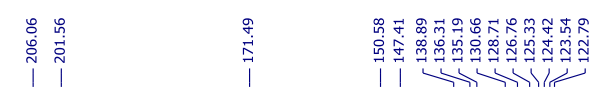

II

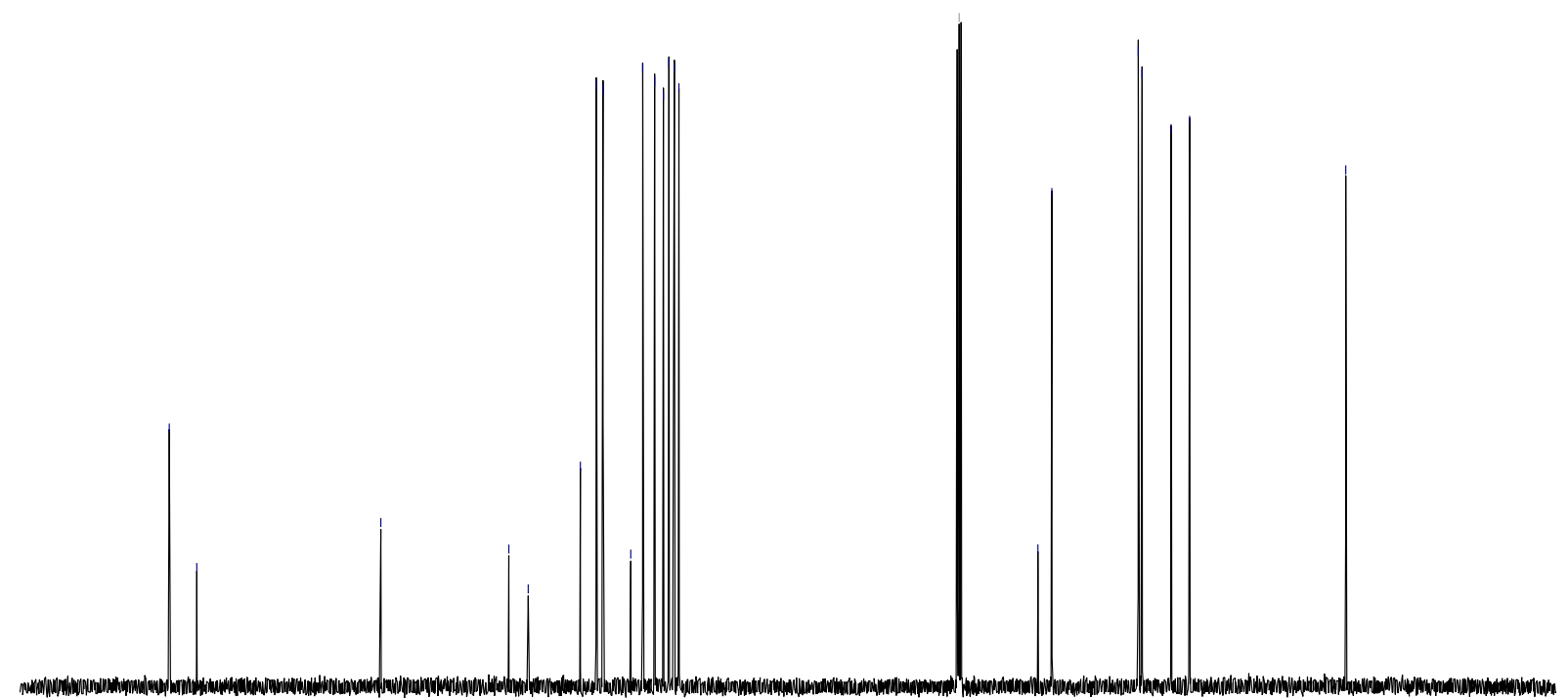

\begin{tabular}{llllllllllllllllllllllllllllll}
\hline 30 & 220 & 210 & 200 & 190 & 180 & 170 & 160 & 150 & 140 & 130 & 120 & 110 & 100 & 90 & 80 & 70 & 60 & 50 & 40 & 30 & 20 & 10 & 0 & -10 & -2
\end{tabular}

$101 \mathrm{MHz}{ }^{13} \mathrm{C}$ NMR of $\mathbf{3 a d}$ in $\mathrm{CDCl}_{3}$. 


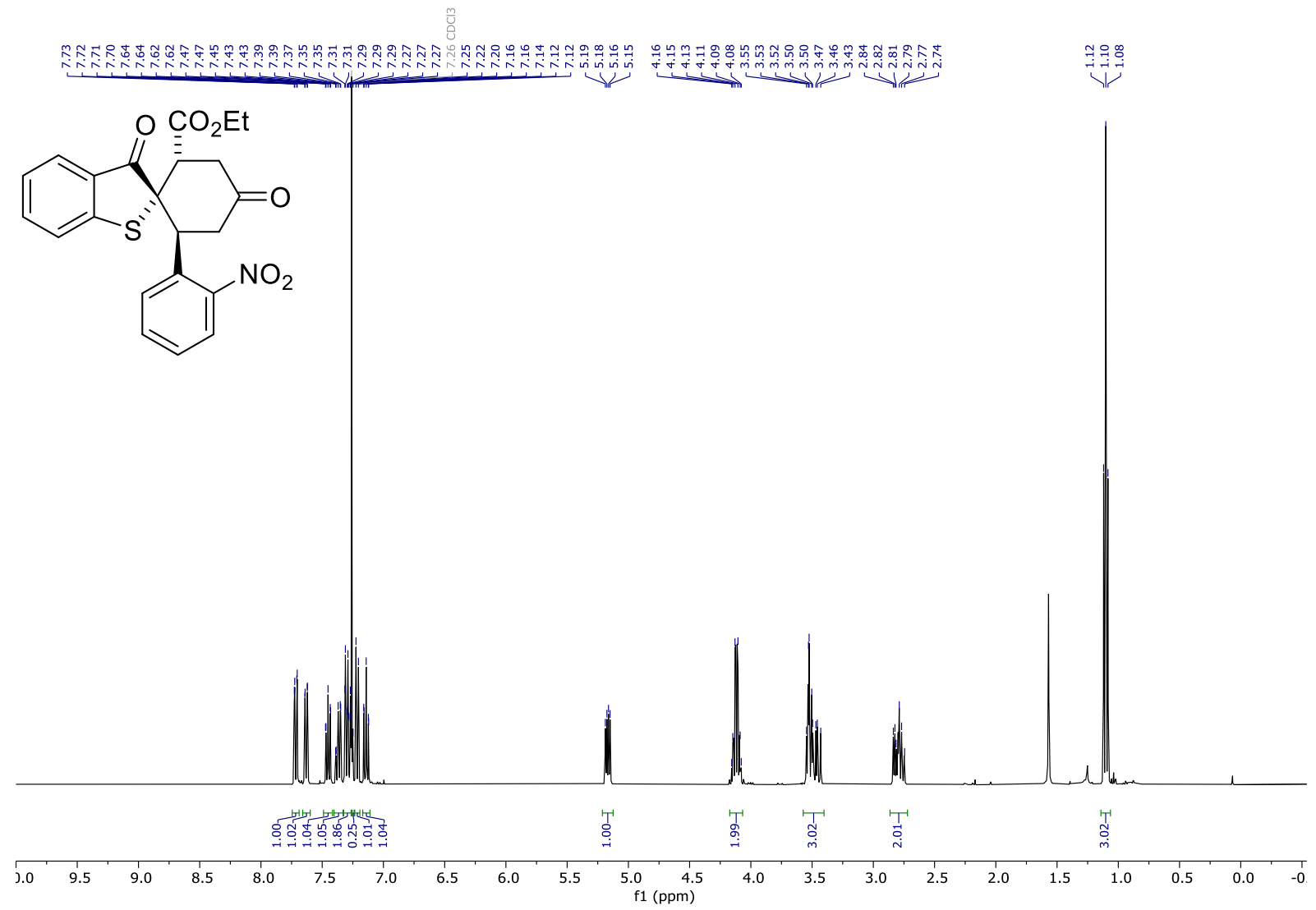

$400 \mathrm{MHz}{ }^{1} \mathrm{H}$ NMR of $\mathbf{3 a e}$ in $\mathrm{CDCl}_{3}$.<smiles>CCO[C@H]1CC(=O)C[C@@H](c2ccccc2[N+](=O)[O-])[C@@]12Sc1ccccc1C2=O</smiles>

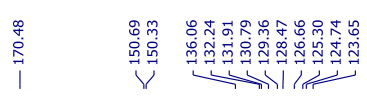

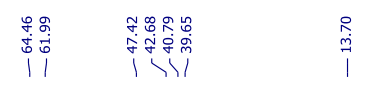

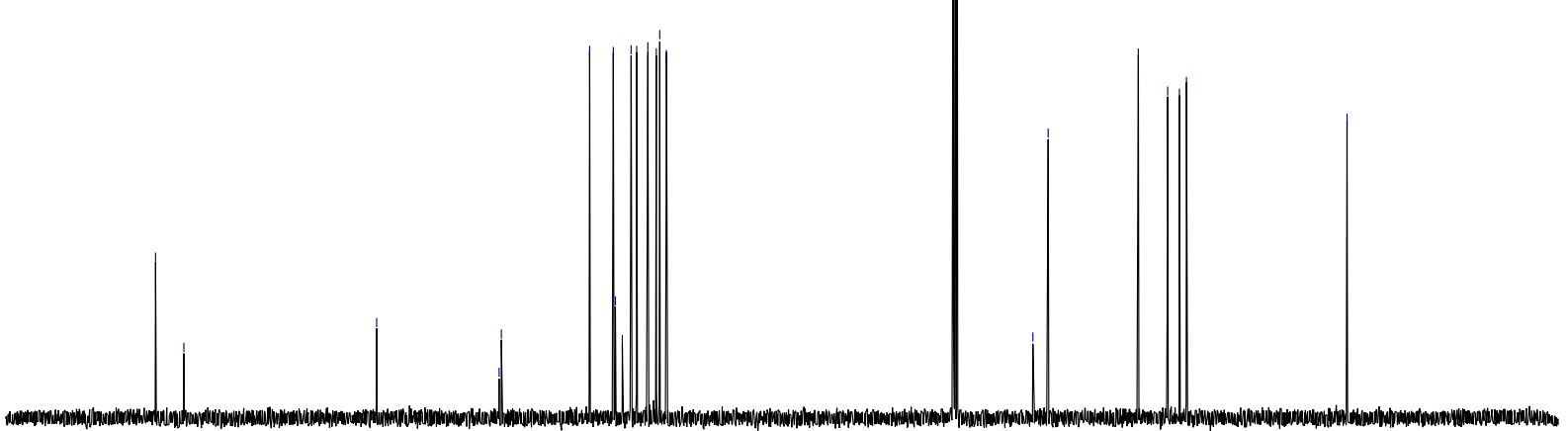

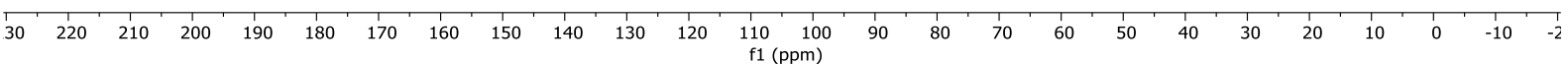

$101 \mathrm{MHz}{ }^{13} \mathrm{C}$ NMR of $\mathbf{3 a e}$ in $\mathrm{CDCl}_{3}$. 


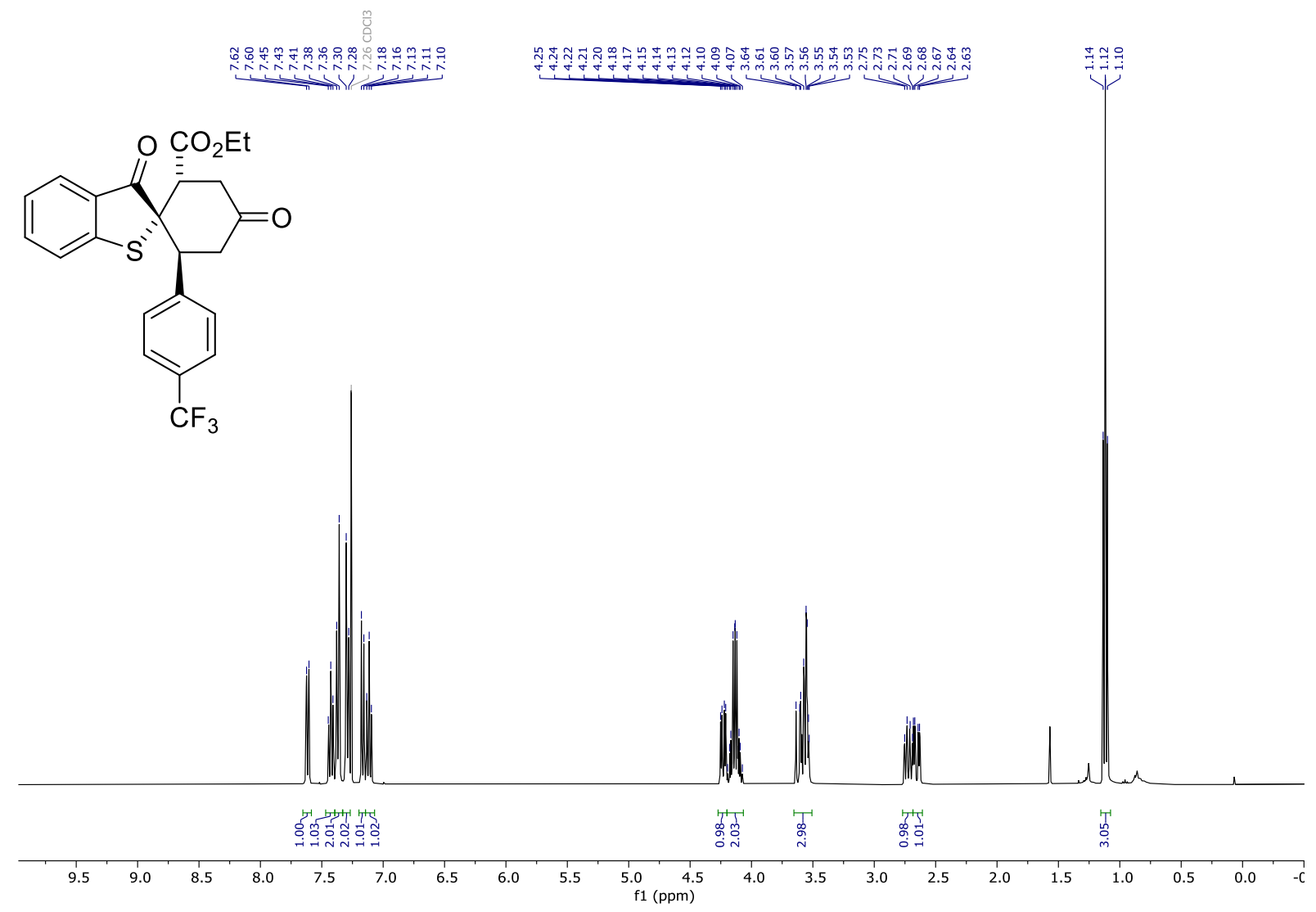

$400 \mathrm{MHz}{ }^{1} \mathrm{H}$ NMR of 3 af in $\mathrm{CDCl}_{3}$.

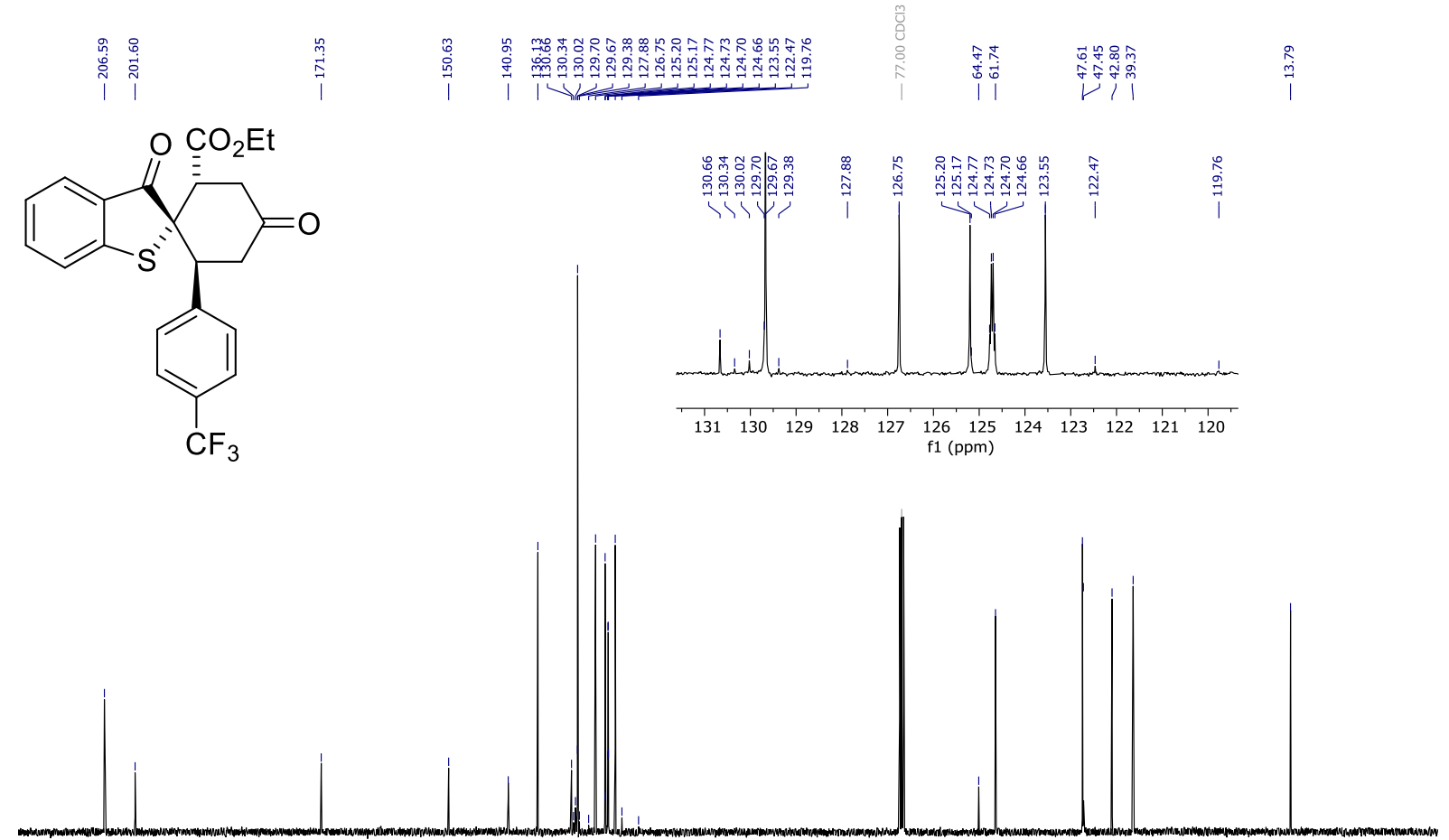

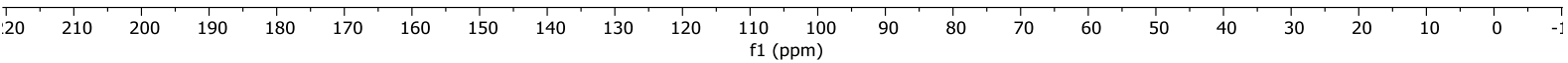

$101 \mathrm{MHz}{ }^{13} \mathrm{C}$ NMR of 3 af in $\mathrm{CDCl}_{3}$. 

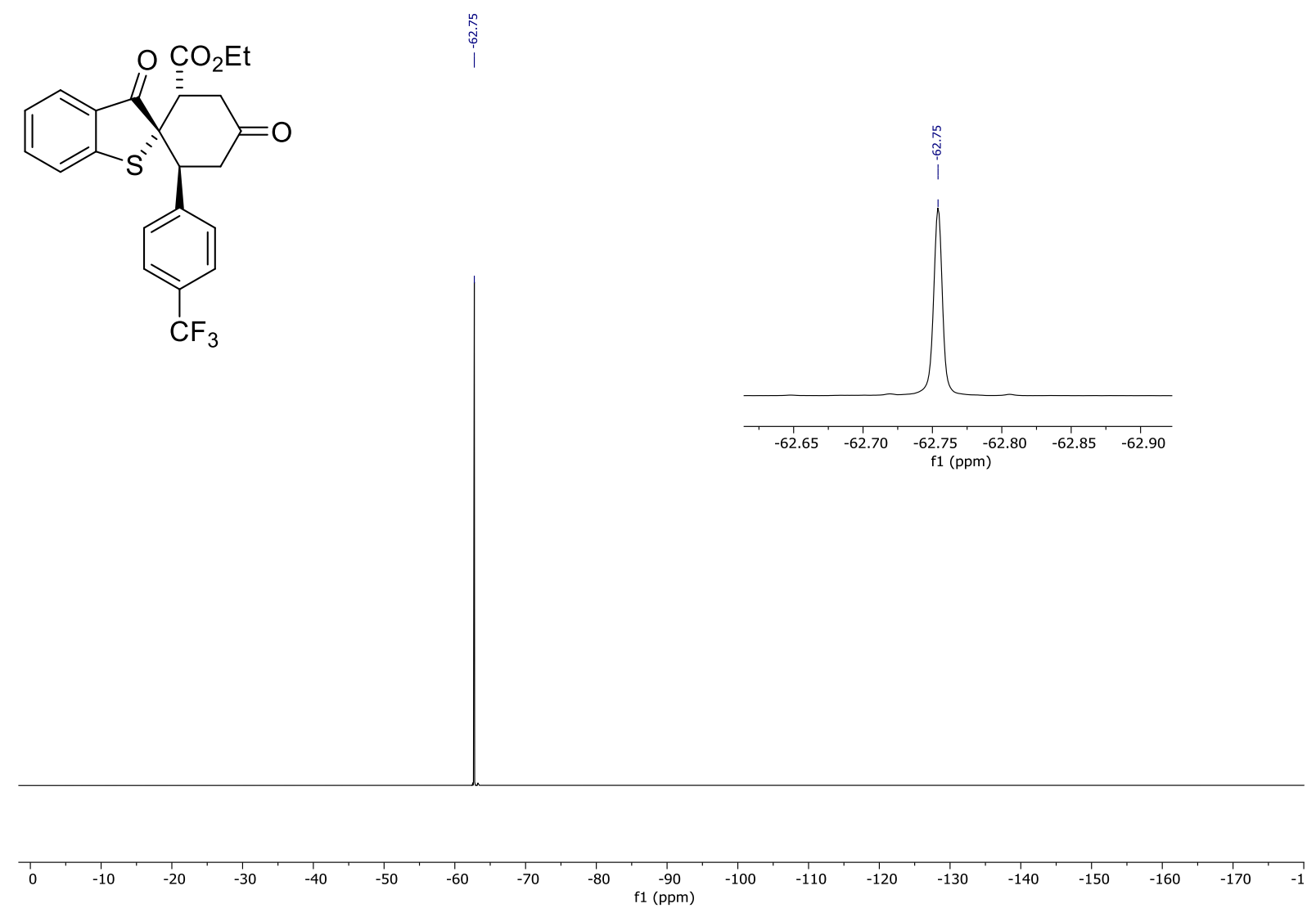

$376 \mathrm{MHz}{ }^{19} \mathrm{~F}$ NMR of 3 af in $\mathrm{CDCl}_{3}$. 


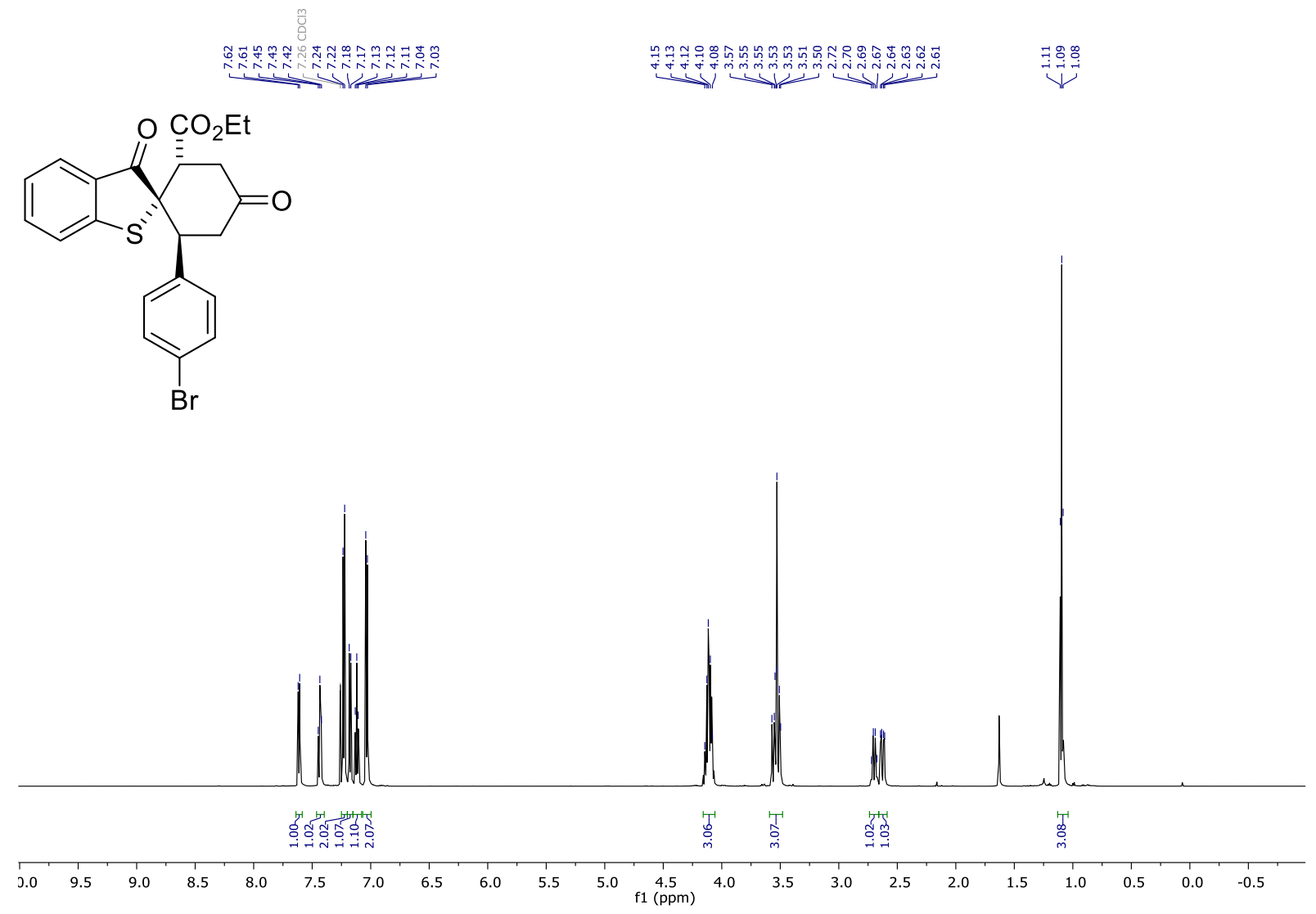

$600 \mathrm{MHz}{ }^{1} \mathrm{H}$ NMR of $\mathbf{3 a g}$ in $\mathrm{CDCl}_{3}$.

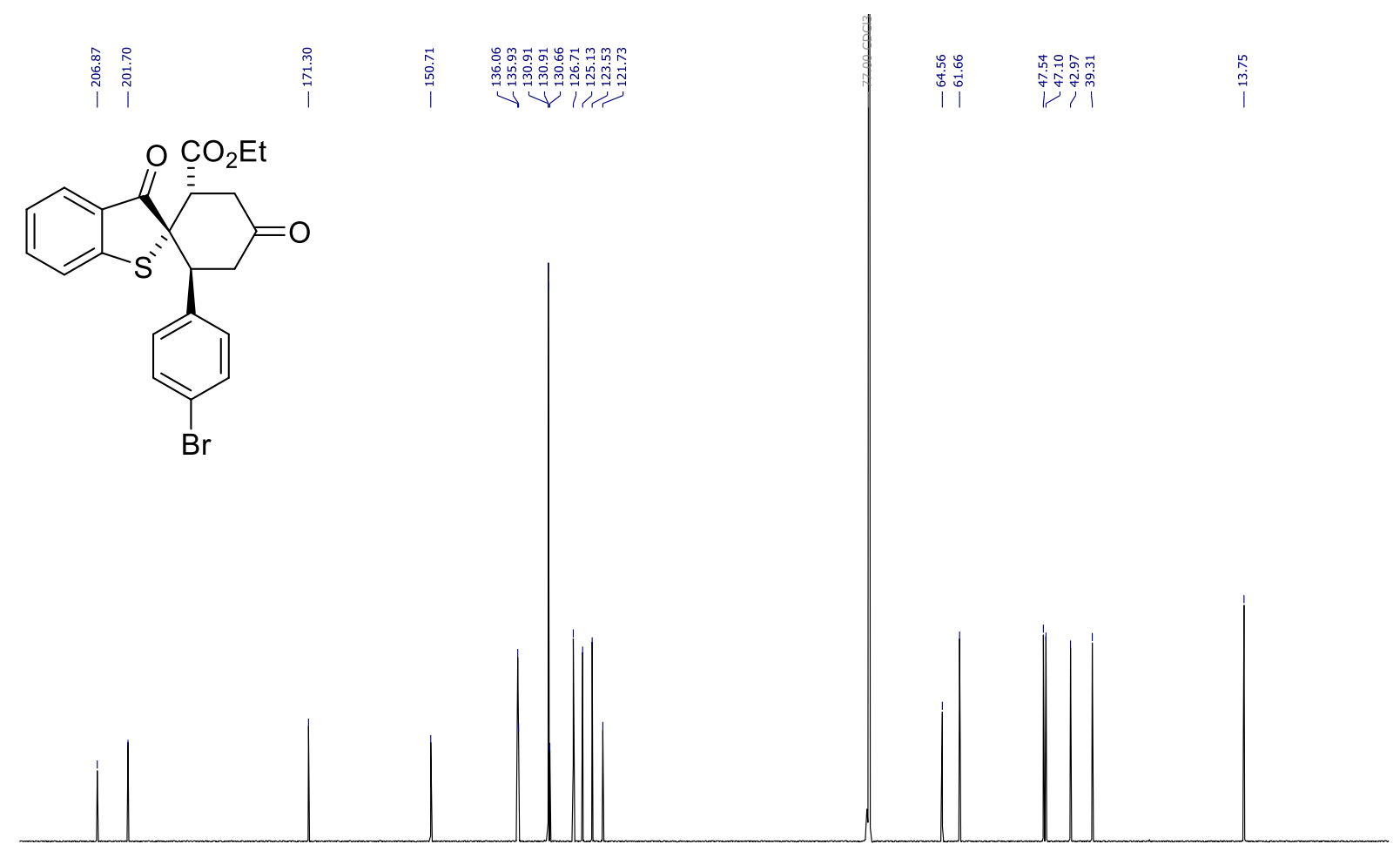

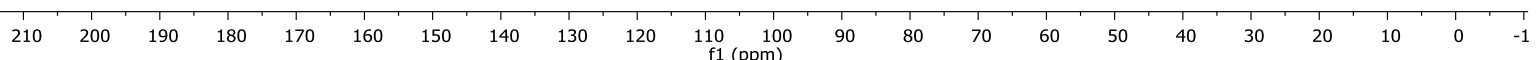

$151 \mathrm{MHz}{ }^{13} \mathrm{C}$ NMR of $\mathbf{3 a g}$ in $\mathrm{CDCl}_{3}$. 


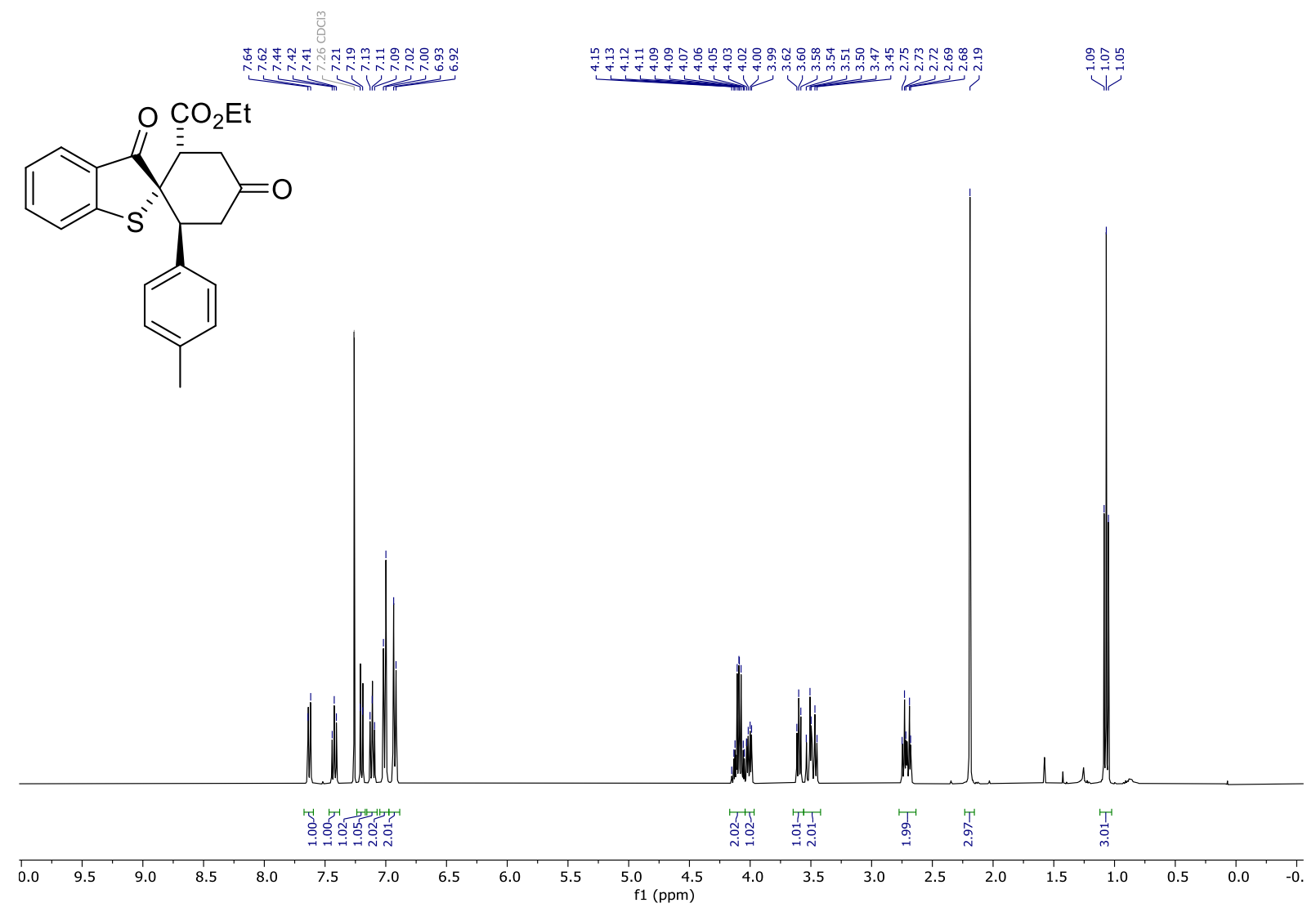

$400 \mathrm{MHz}{ }^{1} \mathrm{H}$ NMR of $\mathbf{3 a h}$ in $\mathrm{CDCl}_{3}$.

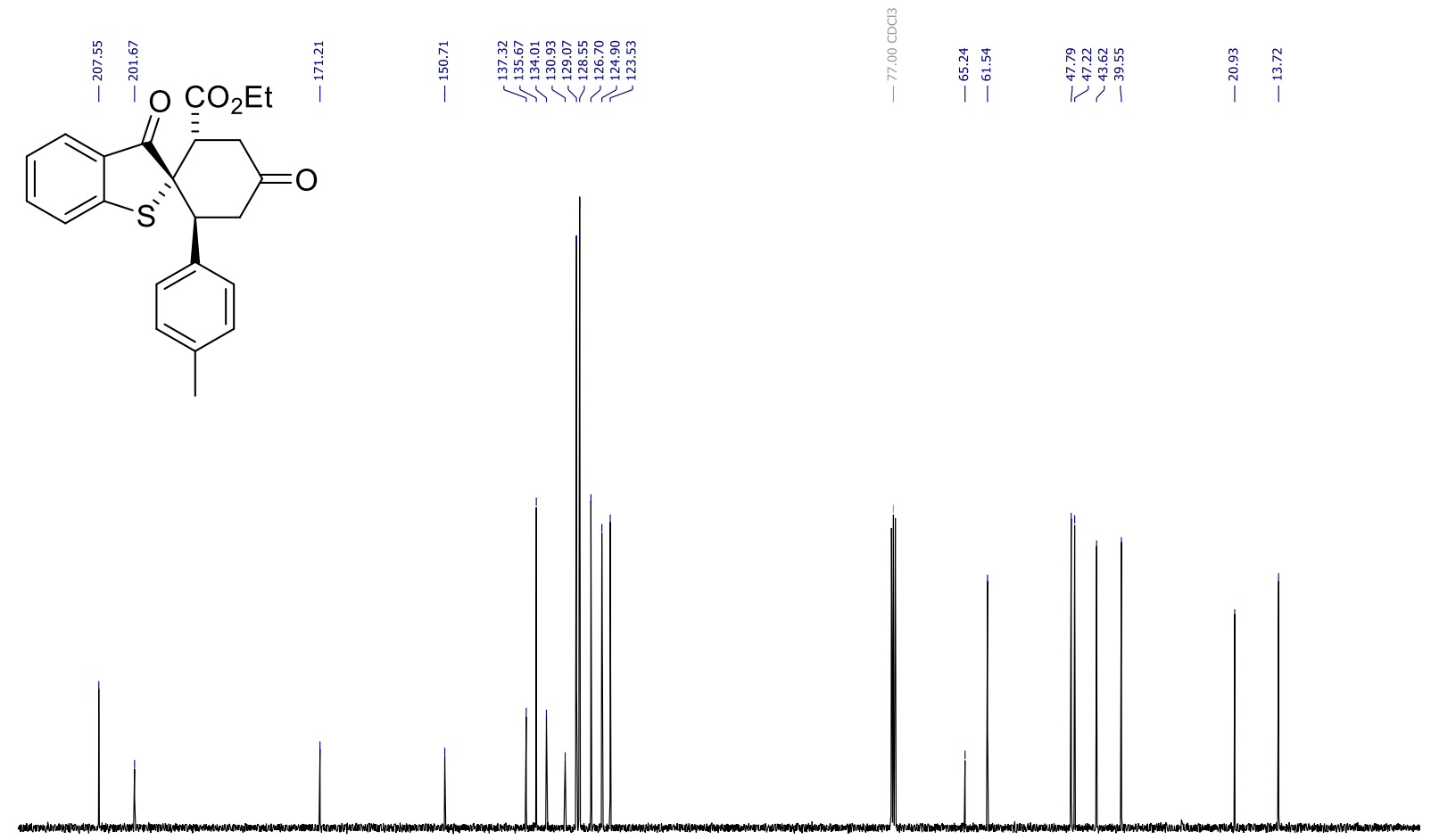

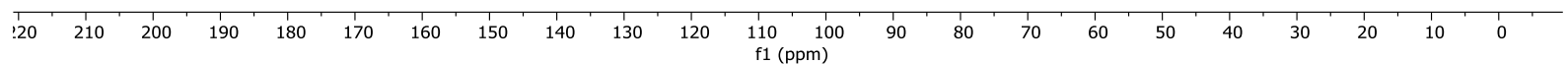

$101 \mathrm{MHz}{ }^{13} \mathrm{C}$ NMR of $\mathbf{3 a h}$ in $\mathrm{CDCl}_{3}$. 
<smiles>CCOC(=O)[C@@]12CC(=O)C[C@@H](c3cccs3)[C@H]1C21Sc2ccccc2C1=O</smiles>

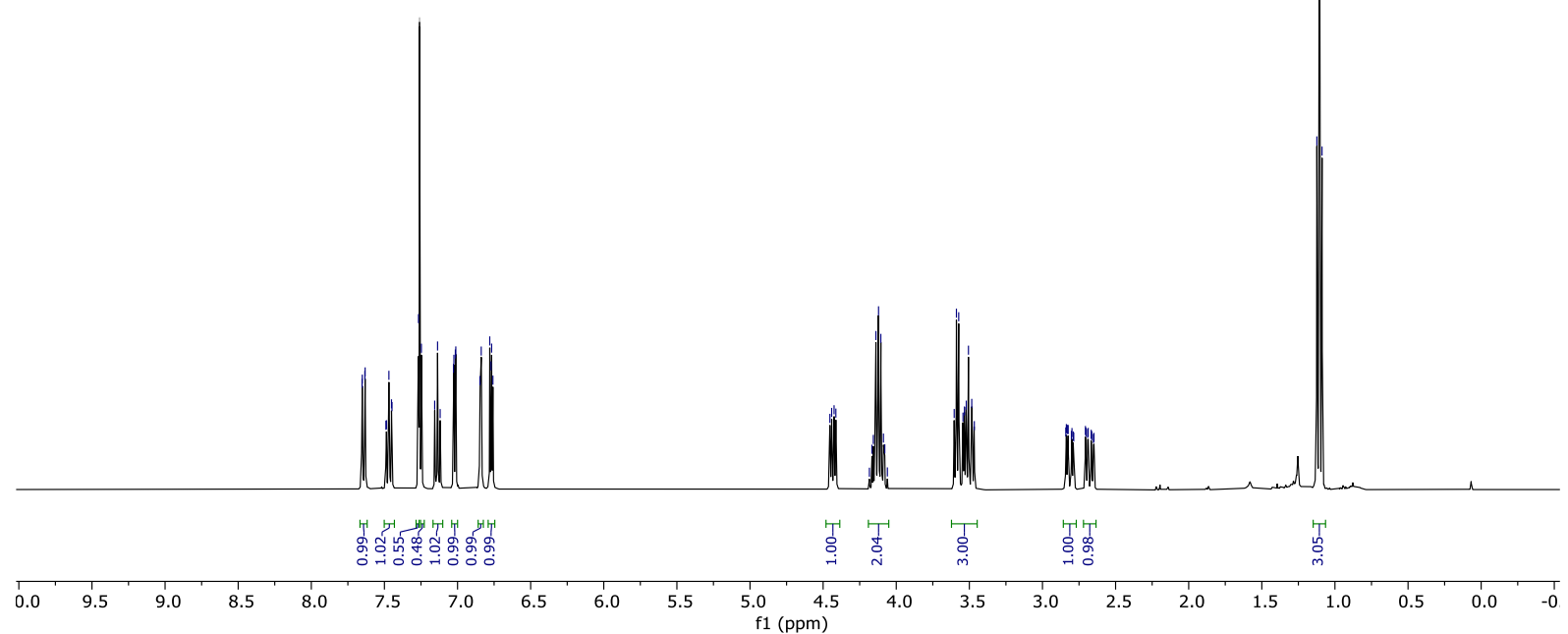

$400 \mathrm{MHz}{ }^{1} \mathrm{H}$ NMR of 3ai in $\mathrm{CDCl}_{3}$.<smiles>CCOC(=O)C1CC(=O)CC(c2cccs2)[C@@]12Sc1ccccc1C2=O</smiles>

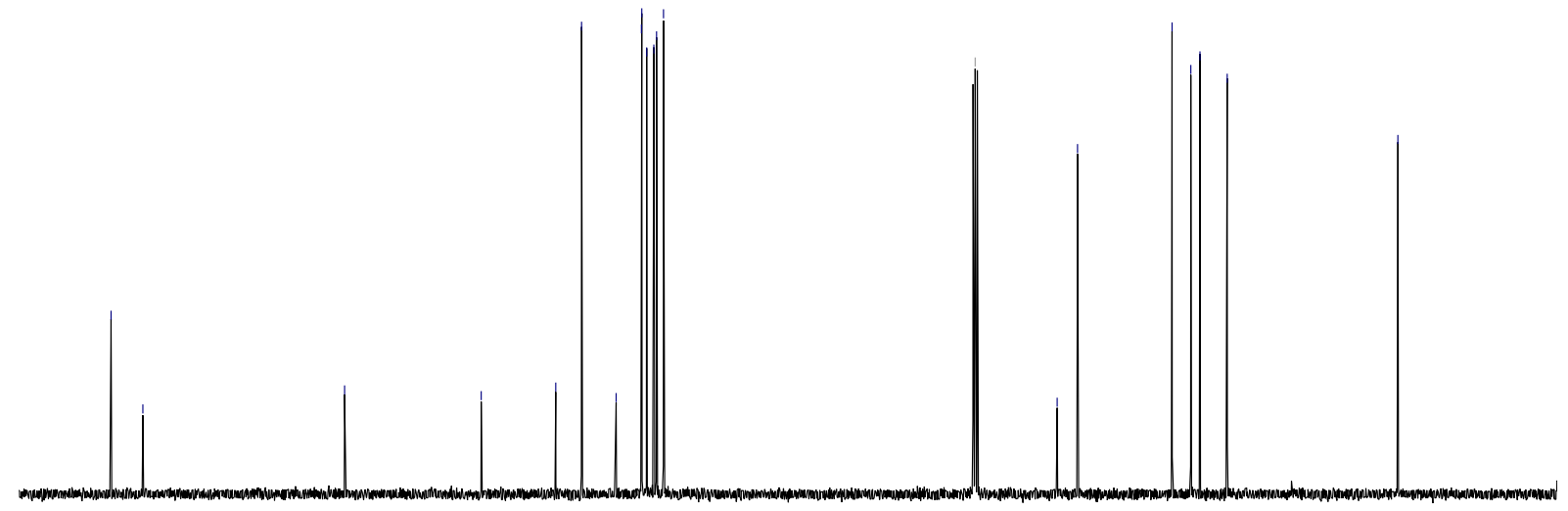

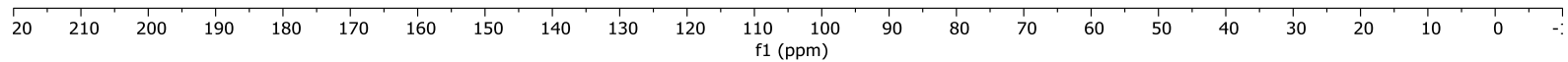
$101 \mathrm{MHz}{ }^{13} \mathrm{C}$ NMR of 3ai in $\mathrm{CDCl}_{3}$. 


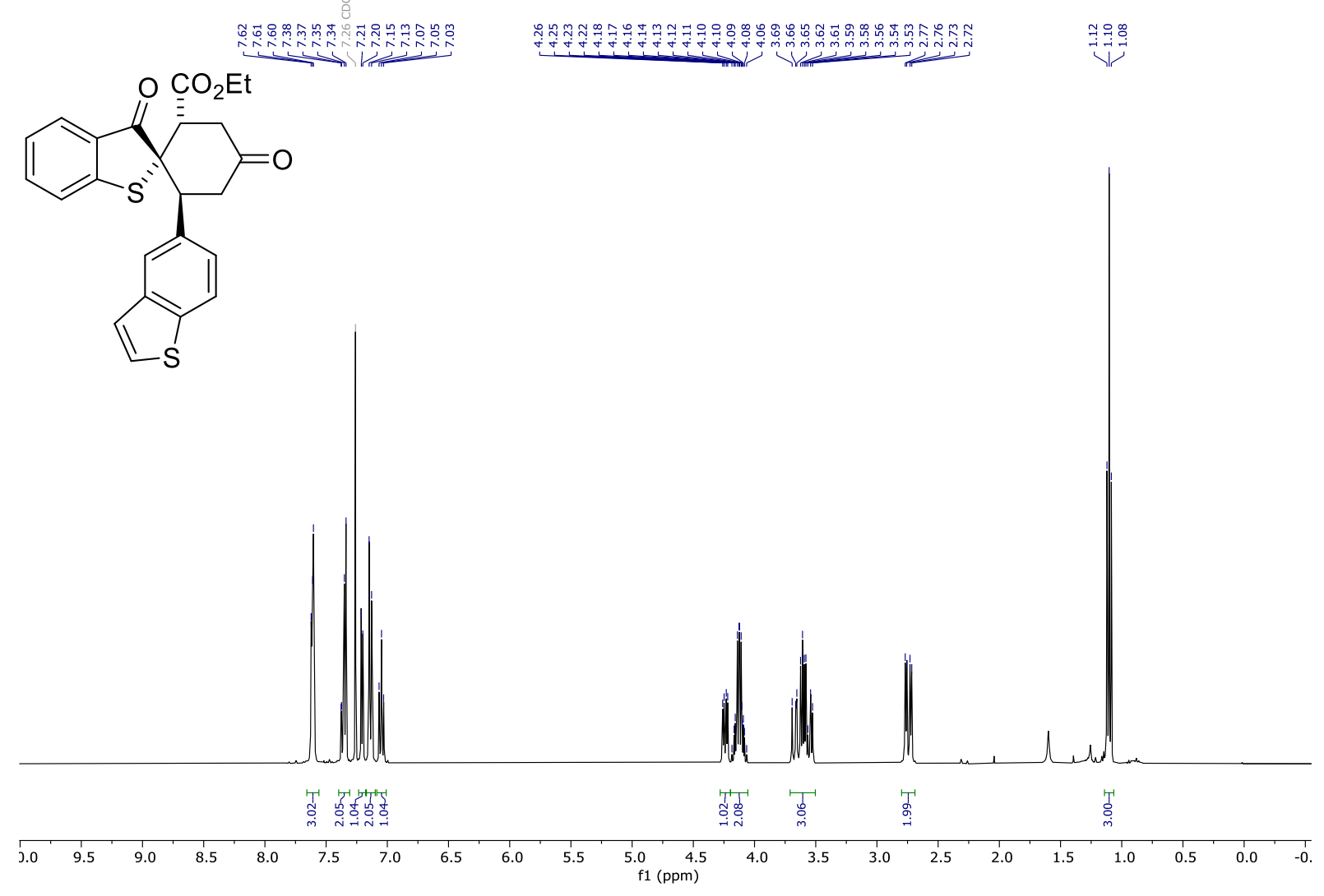

$400 \mathrm{MHz}{ }^{1} \mathrm{H}$ NMR of 3aj in $\mathrm{CDCl}_{3}$.

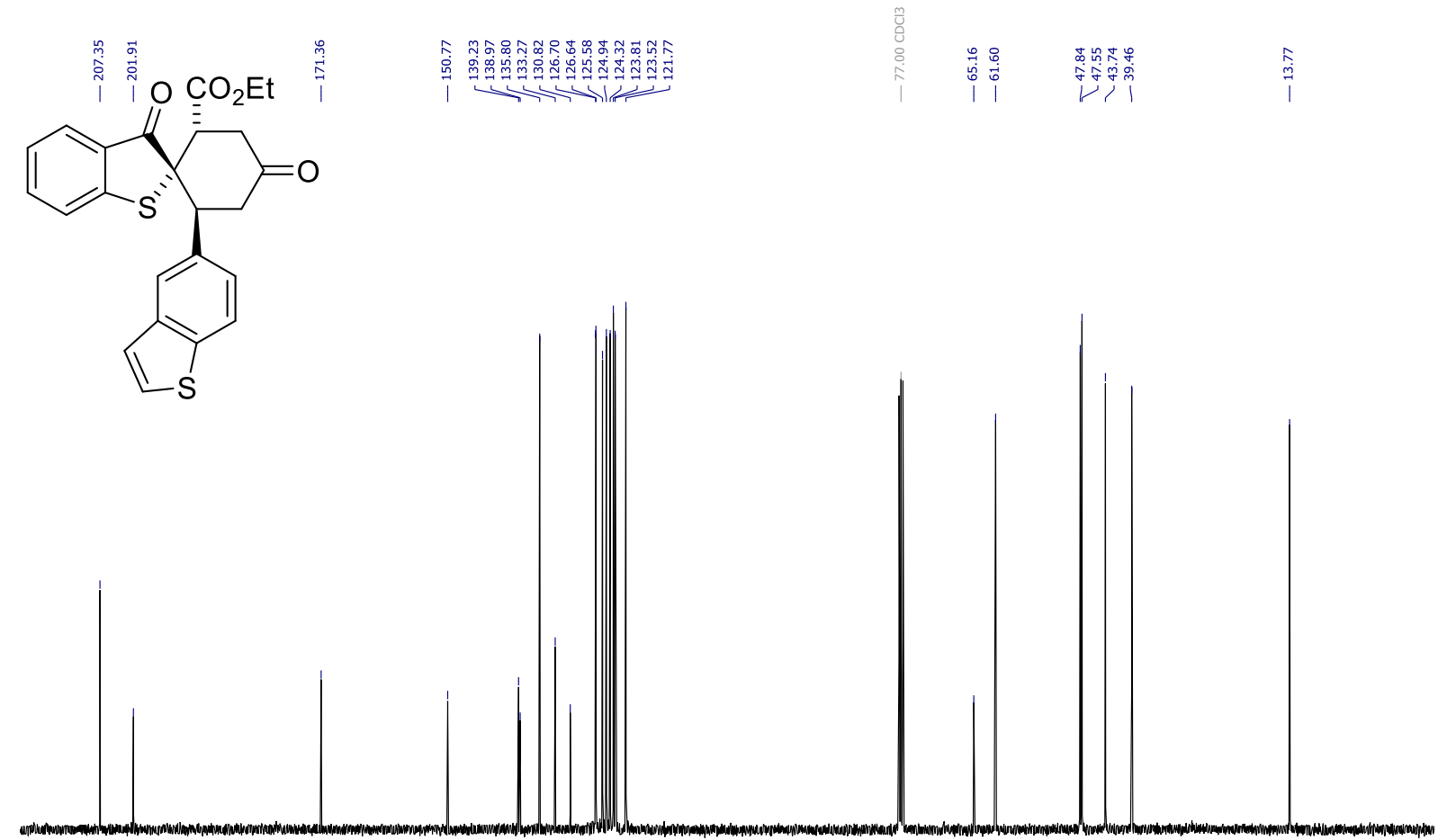

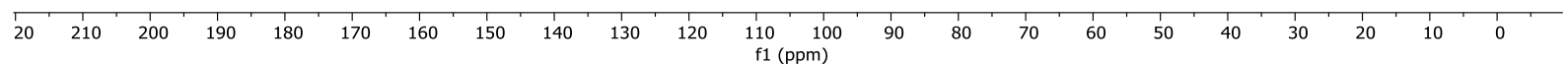
$101 \mathrm{MHz}{ }^{13} \mathrm{C}$ NMR of $\mathbf{3 a j}$ in $\mathrm{CDCl}_{3}$. 


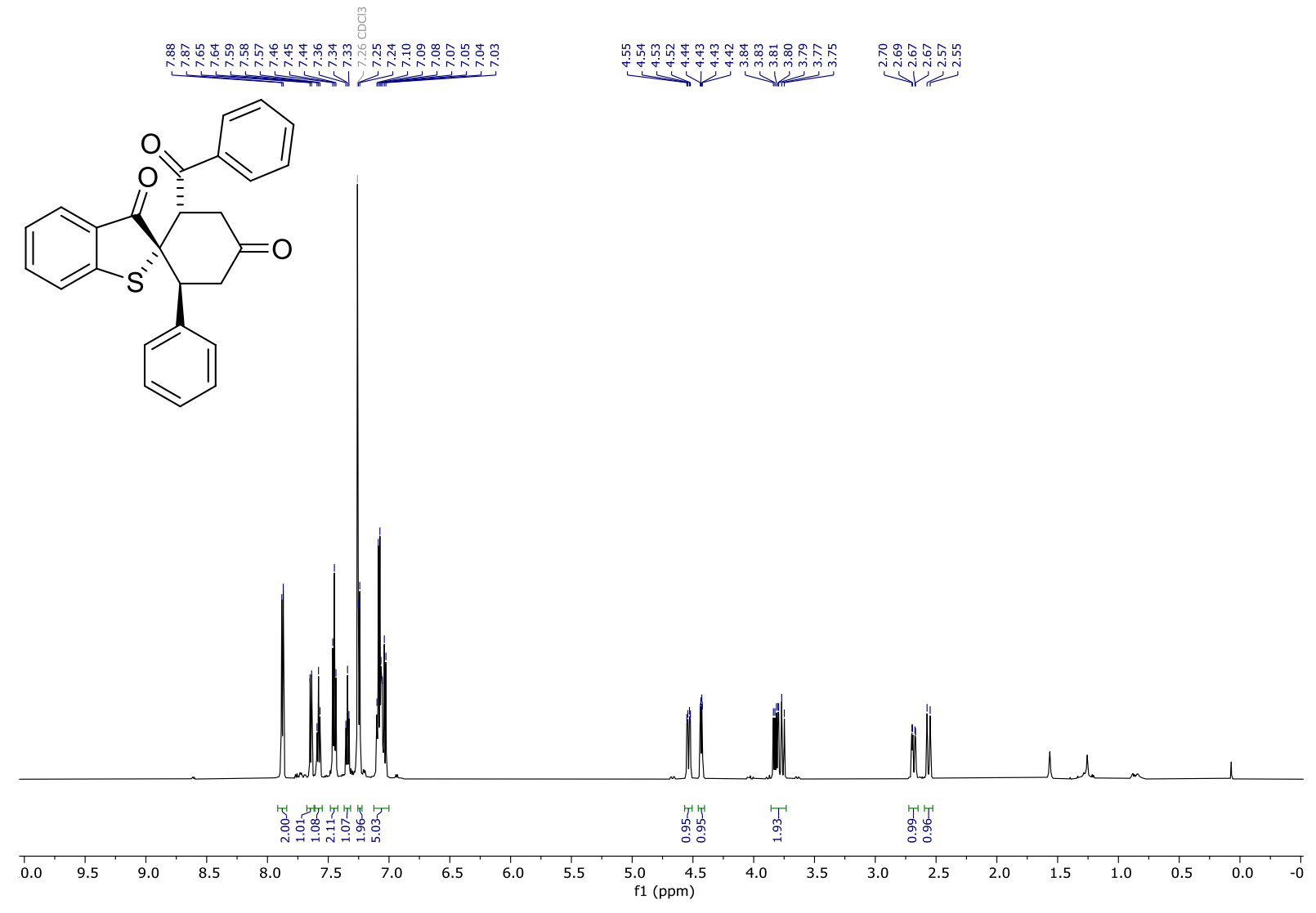

$600 \mathrm{MHz}{ }^{1} \mathrm{H}$ NMR of $\mathbf{3 d a}$ in $\mathrm{CDCl}_{3}$.

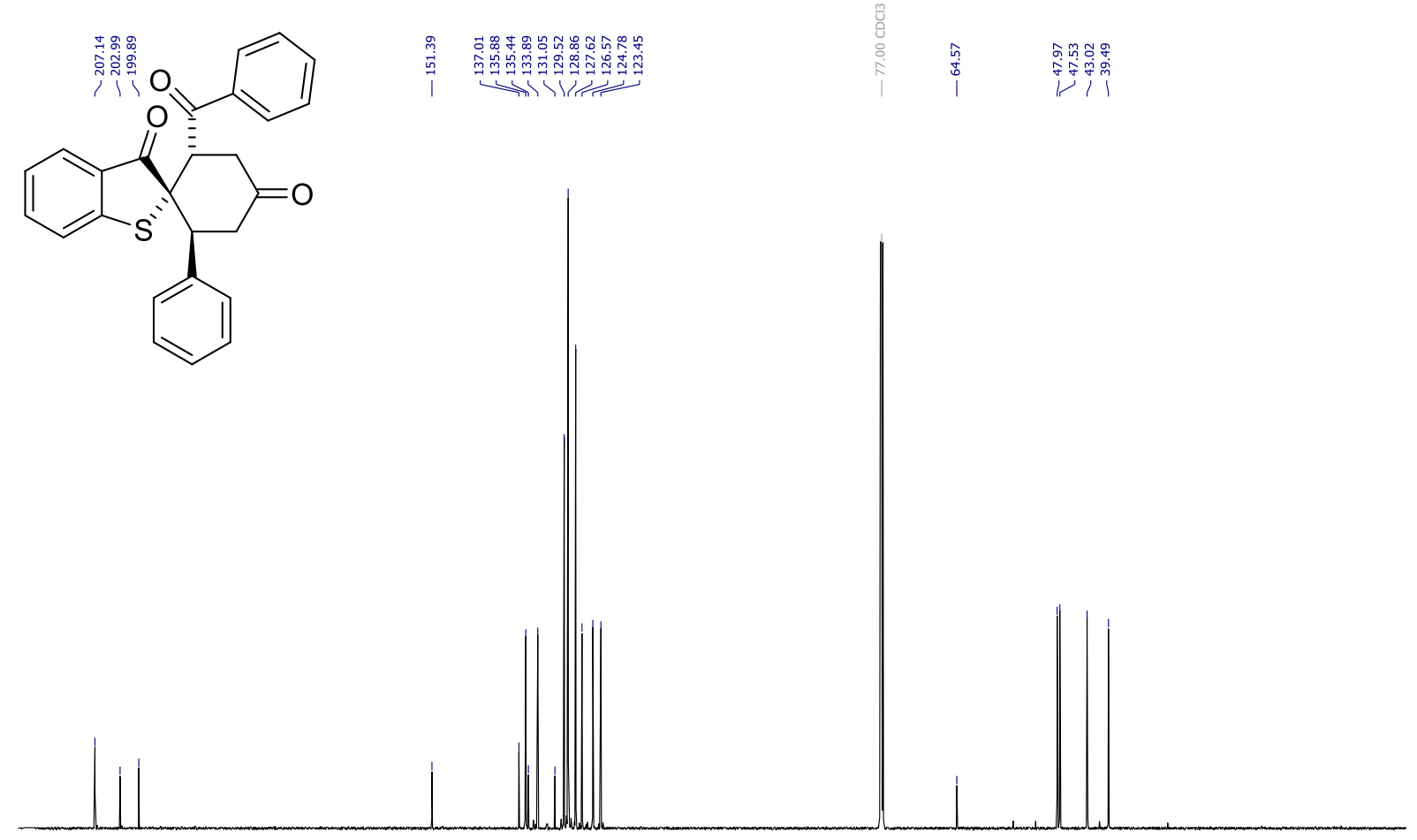

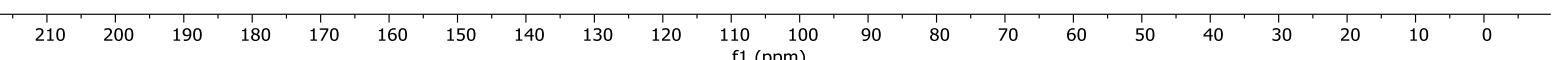
$151 \mathrm{MHz}{ }^{13} \mathrm{C}$ NMR of $3 d a$ in $\mathrm{CDCl}_{3}$. 


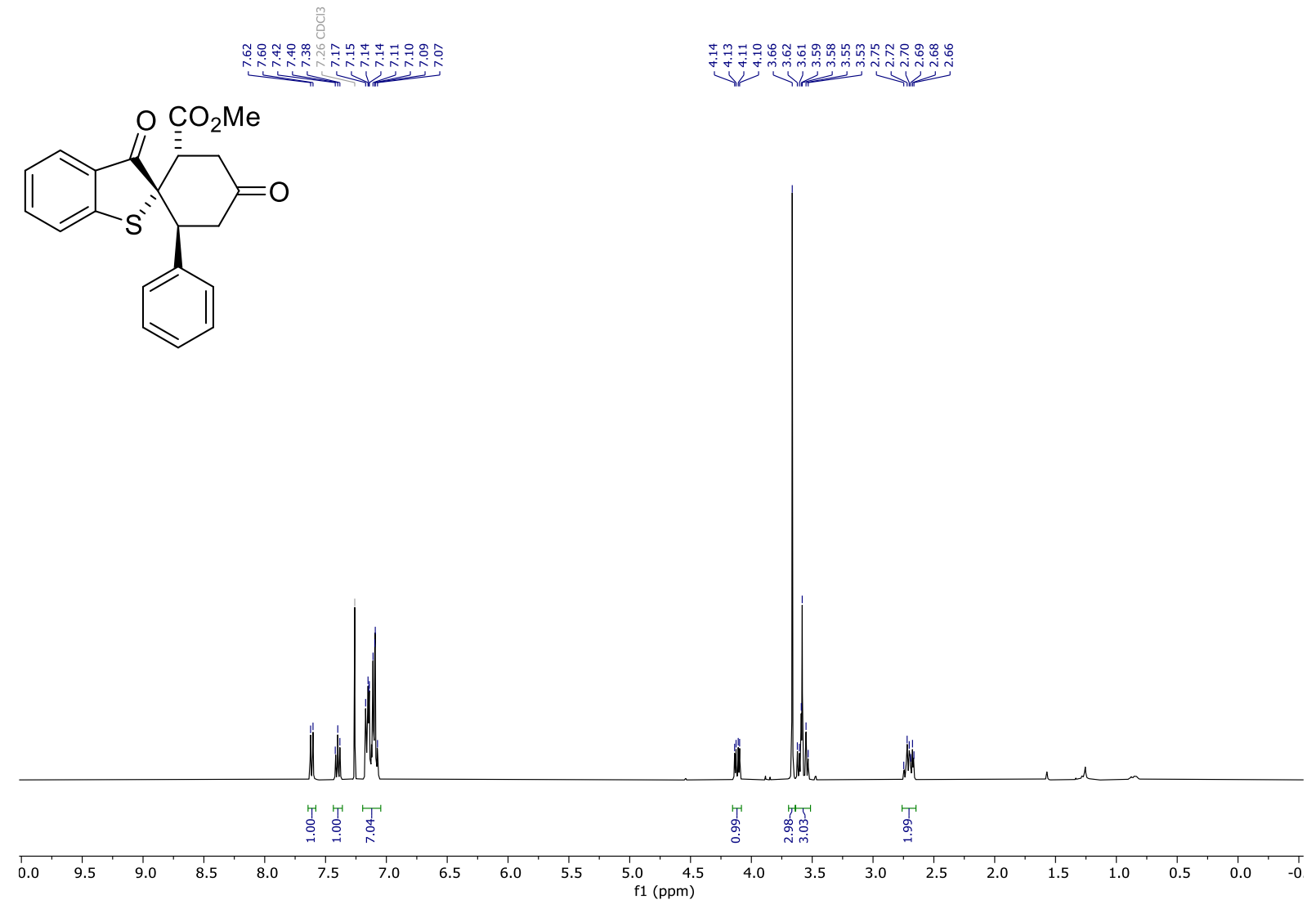

$400 \mathrm{MHz}{ }^{1} \mathrm{H} \mathrm{NMR}$ of $3 \mathbf{e a}$ in $\mathrm{CDCl}_{3}$.

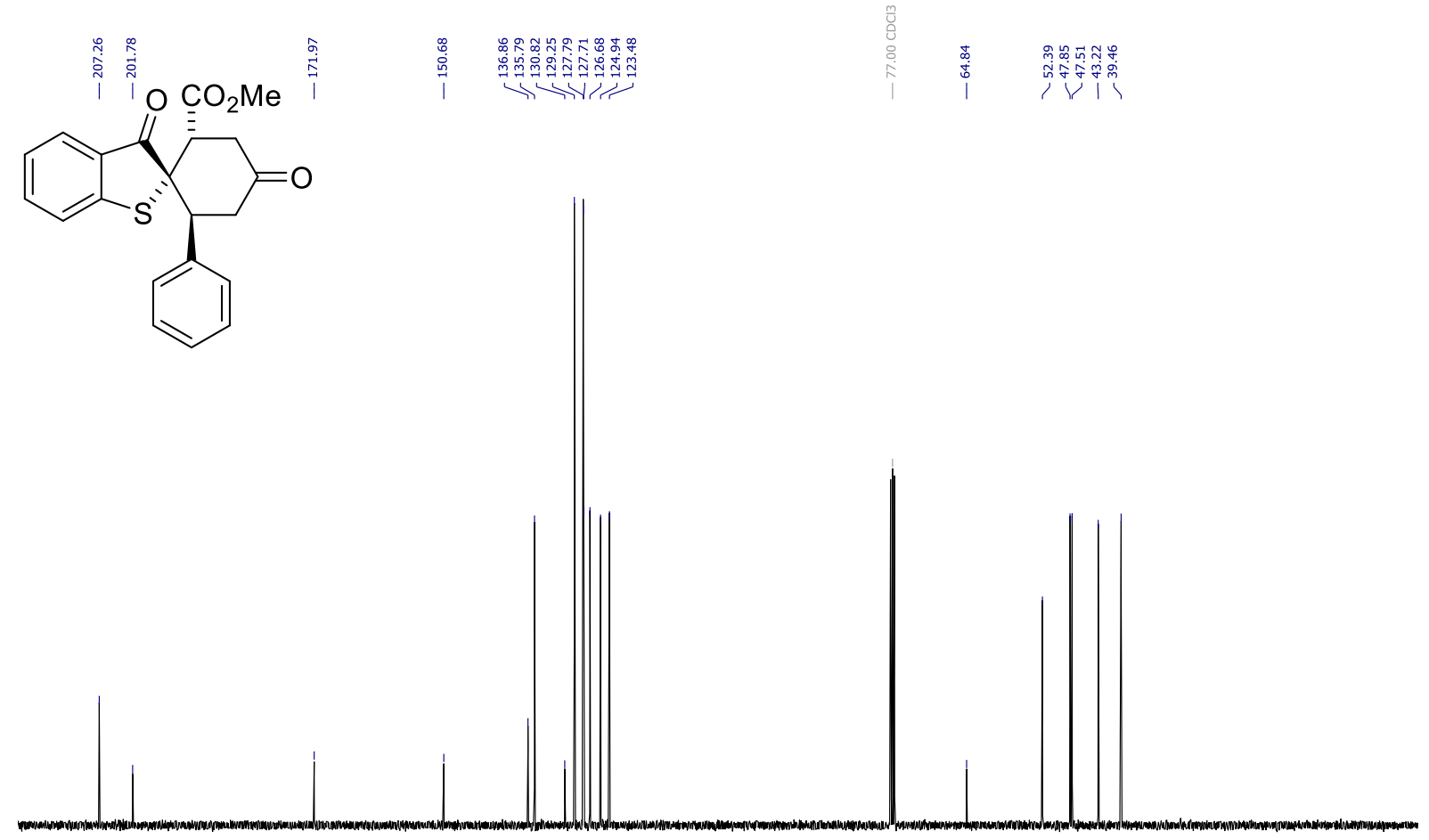

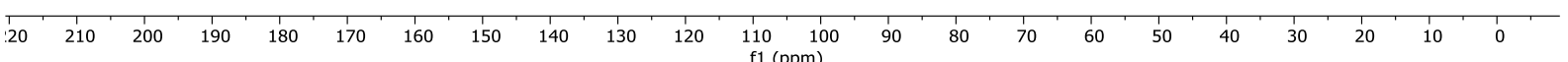
$101 \mathrm{MHz}{ }^{13} \mathrm{NMR}$ of $3 \mathbf{e a}$ in $\mathrm{CDCl}_{3}$. 


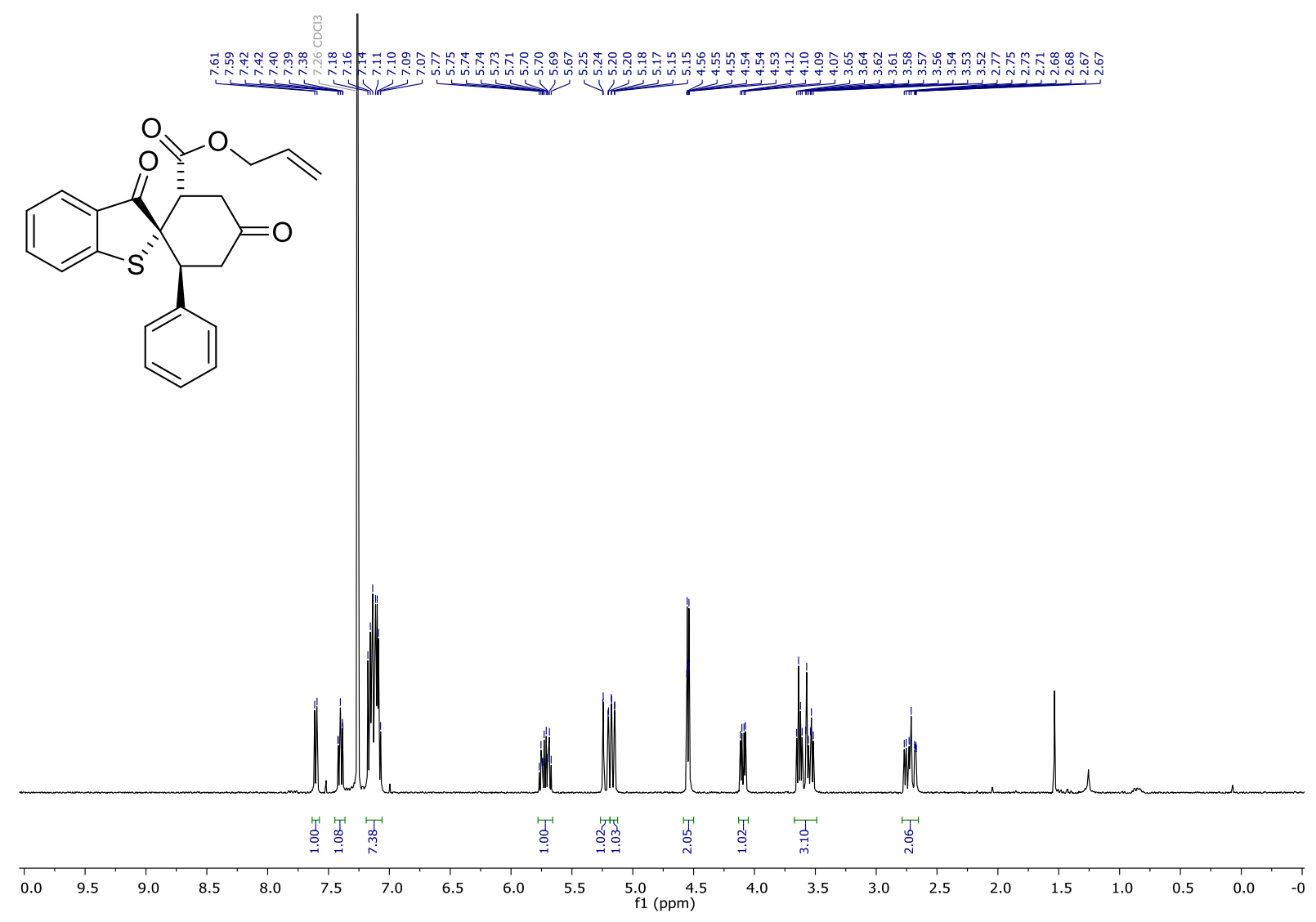

$400 \mathrm{MHz}{ }^{1} \mathrm{H}$ NMR of $\mathbf{3 f a}$ in $\mathrm{CDCl}_{3}$.
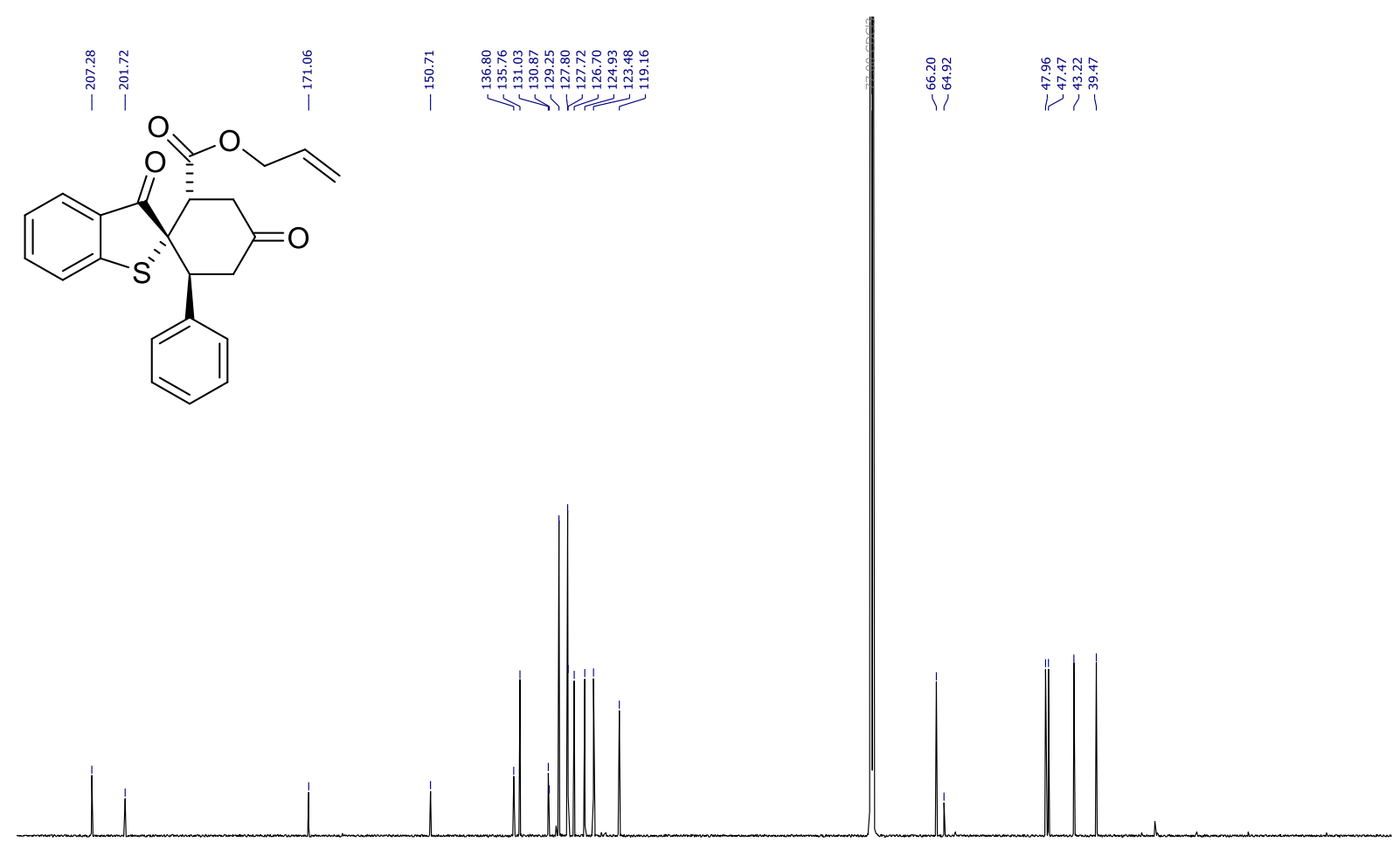

\begin{tabular}{lllllllllll}
210 & 200 & 190 & 180 & 170 & 160 & 150 & 140 & 130 & 120 & $\begin{array}{c}110 \\
\mathrm{f} 1(\mathrm{ppm})\end{array}$ \\
\hline
\end{tabular}

$101 \mathrm{MHz}{ }^{13} \mathrm{NMR}$ of $\mathbf{3 f a}$ in $\mathrm{CDCl}_{3}$. 


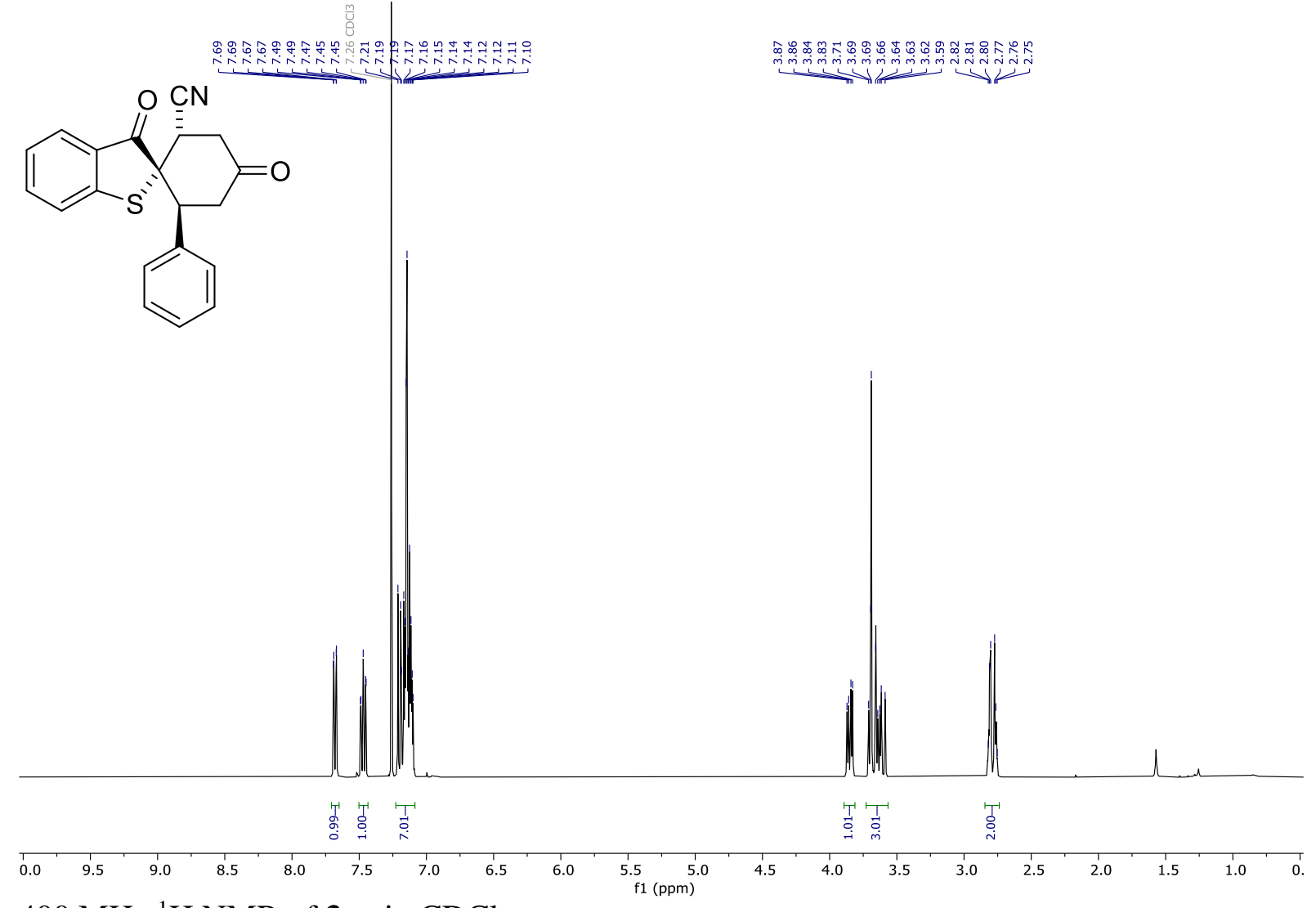

$400 \mathrm{MHz}{ }^{1} \mathrm{H} \mathrm{NMR}$ of $\mathbf{3 g a}$ in $\mathrm{CDCl}_{3}$.<smiles>COC(=O)C1(C#N)CC(=O)C[C@@H](c2ccccc2)[C@]12Cc1ccccc1S2</smiles>

|

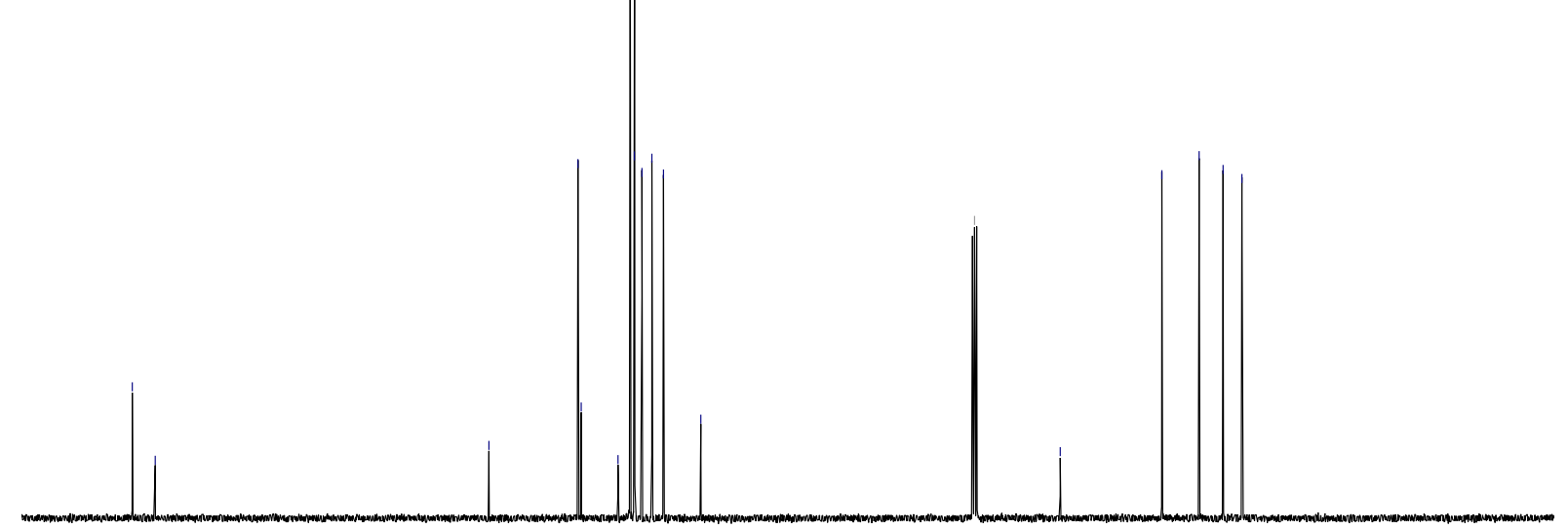

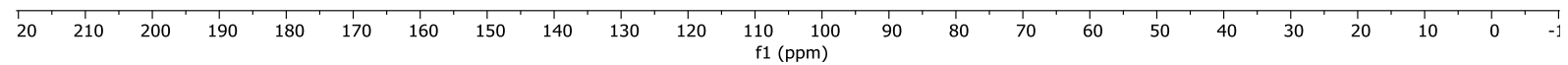
$101 \mathrm{MHz}^{13} \mathrm{NMR}$ of $\mathbf{3 g a}$ in $\mathrm{CDCl}_{3}$. 


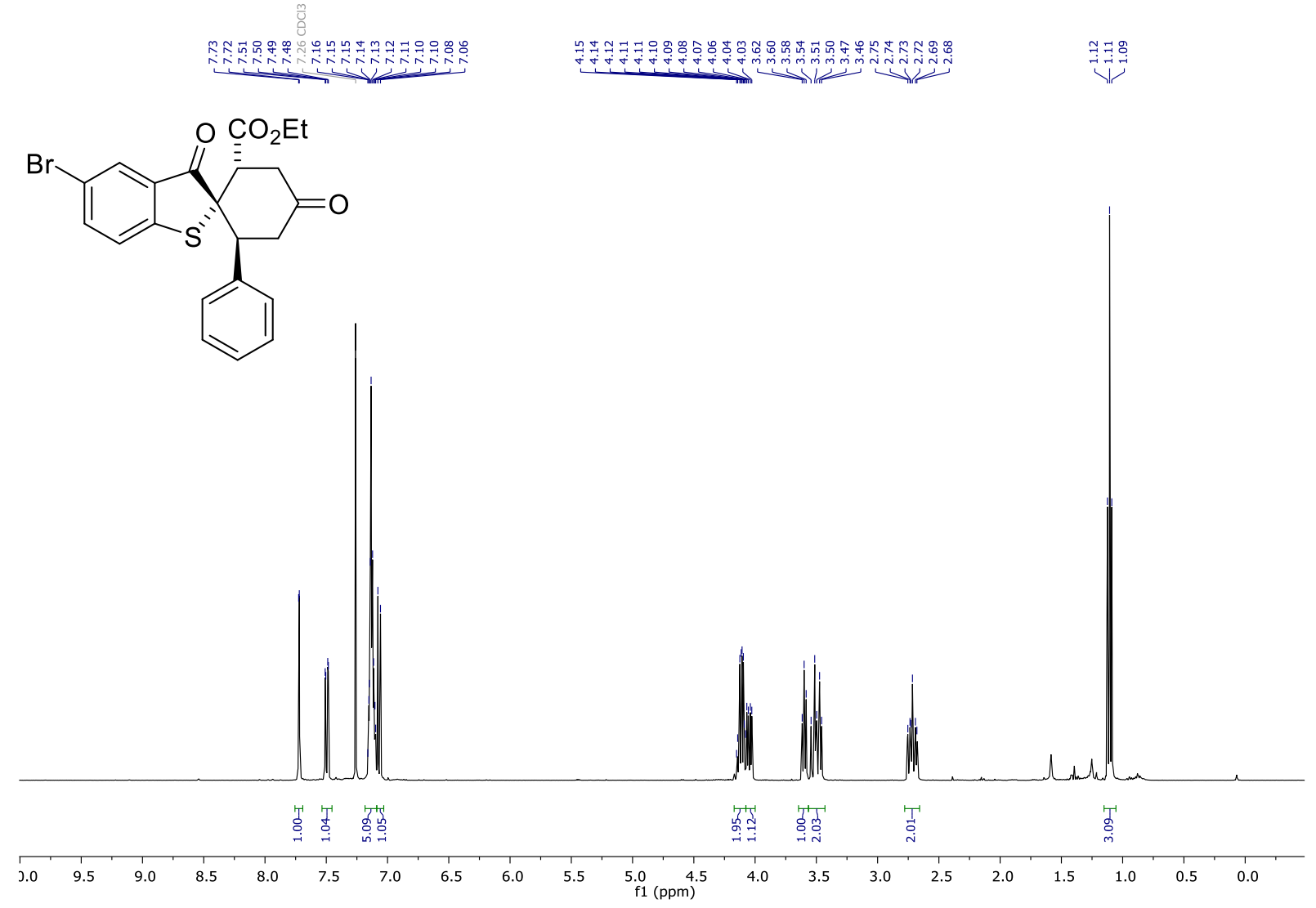

$400 \mathrm{MHz}{ }^{1} \mathrm{H} \mathrm{NMR}$ of 3 ha in $\mathrm{CDCl}_{3}$.

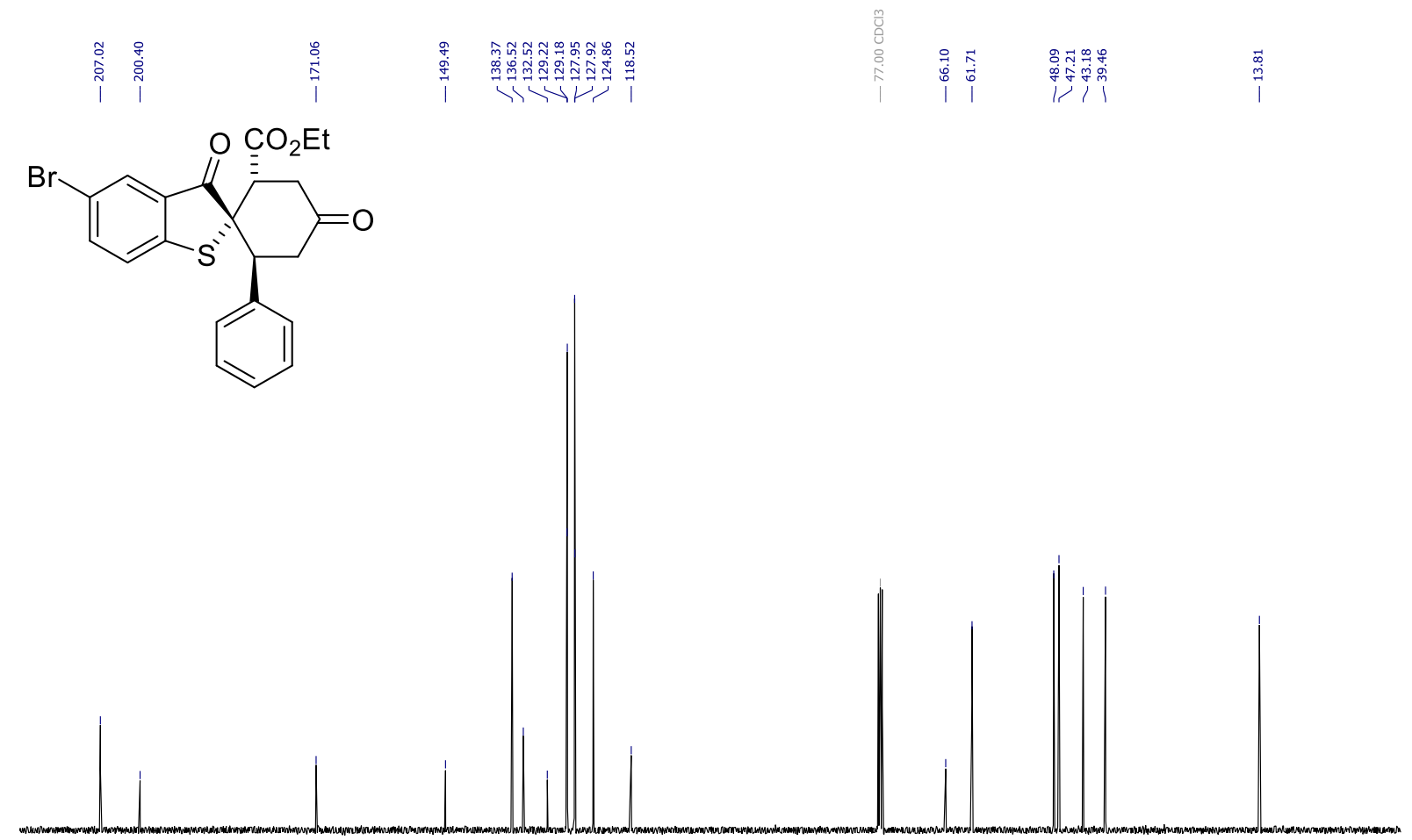

\begin{tabular}{llllllllllllllllllllllll}
\hline & 1 \\
20 & 210 & 200 & 190 & 180 & 170 & 160 & 150 & 140 & 130 & 120 & 110 & 100 & 90 & 80 & 70 & 60 & 50 & 40 & 30 & 20 & 10 & 0 & 1
\end{tabular}

$101 \mathrm{MHz}{ }^{13} \mathrm{NMR}$ of 3 ha in $\mathrm{CDCl}_{3}$. 


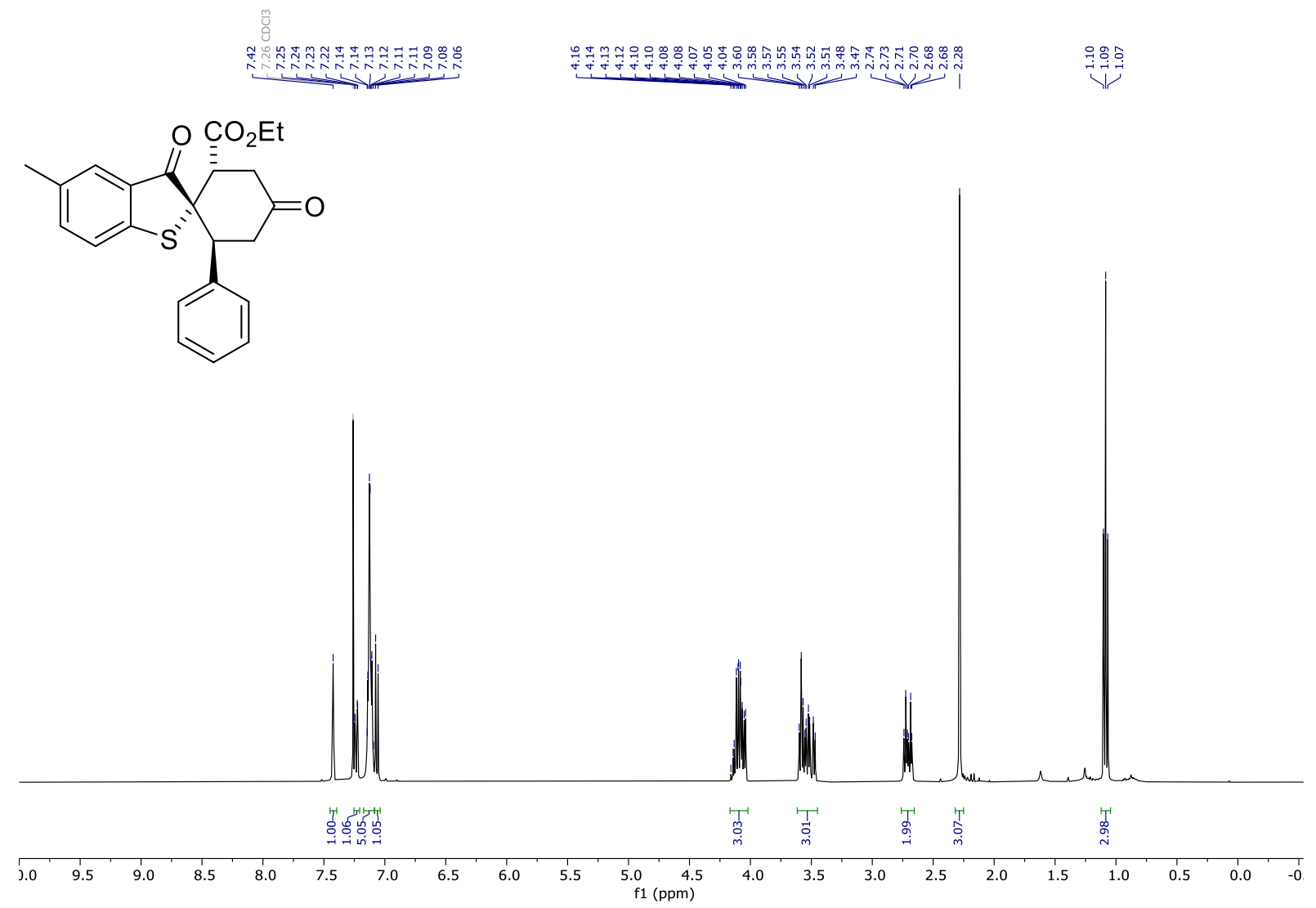

$400 \mathrm{MHz}{ }^{1} \mathrm{H}$ NMR of 3ia in $\mathrm{CDCl}_{3}$.

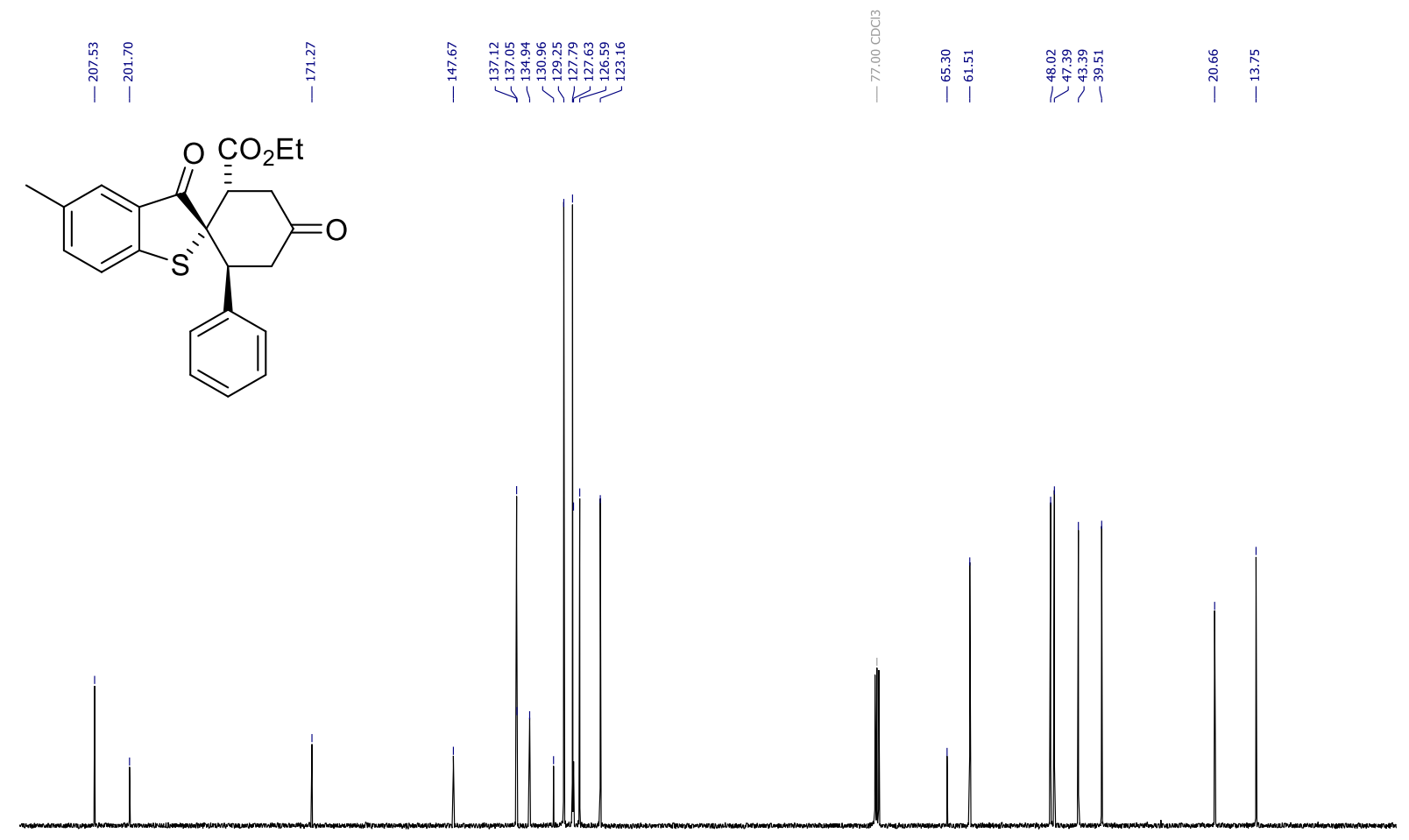

\begin{tabular}{|l|llllllllllllllllllllll}
\hline 20 & 210 & 200 & 190 & 180 & 170 & 160 & 150 & 140 & 130 & 120 & 110 & 100 & 90 & 80 & 70 & 60 & 50 & 40 & 30 & 20 & 10 & 0
\end{tabular} $101 \mathrm{MHz}{ }^{13} \mathrm{NMR}$ of 3 ia in $\mathrm{CDCl}_{3}$. 
<smiles>CCOC(=O)[C@H]1CC(=O)C[C@H](c2ccccc2)[C@@]12Sc1cccc(C)c1C2=O</smiles>
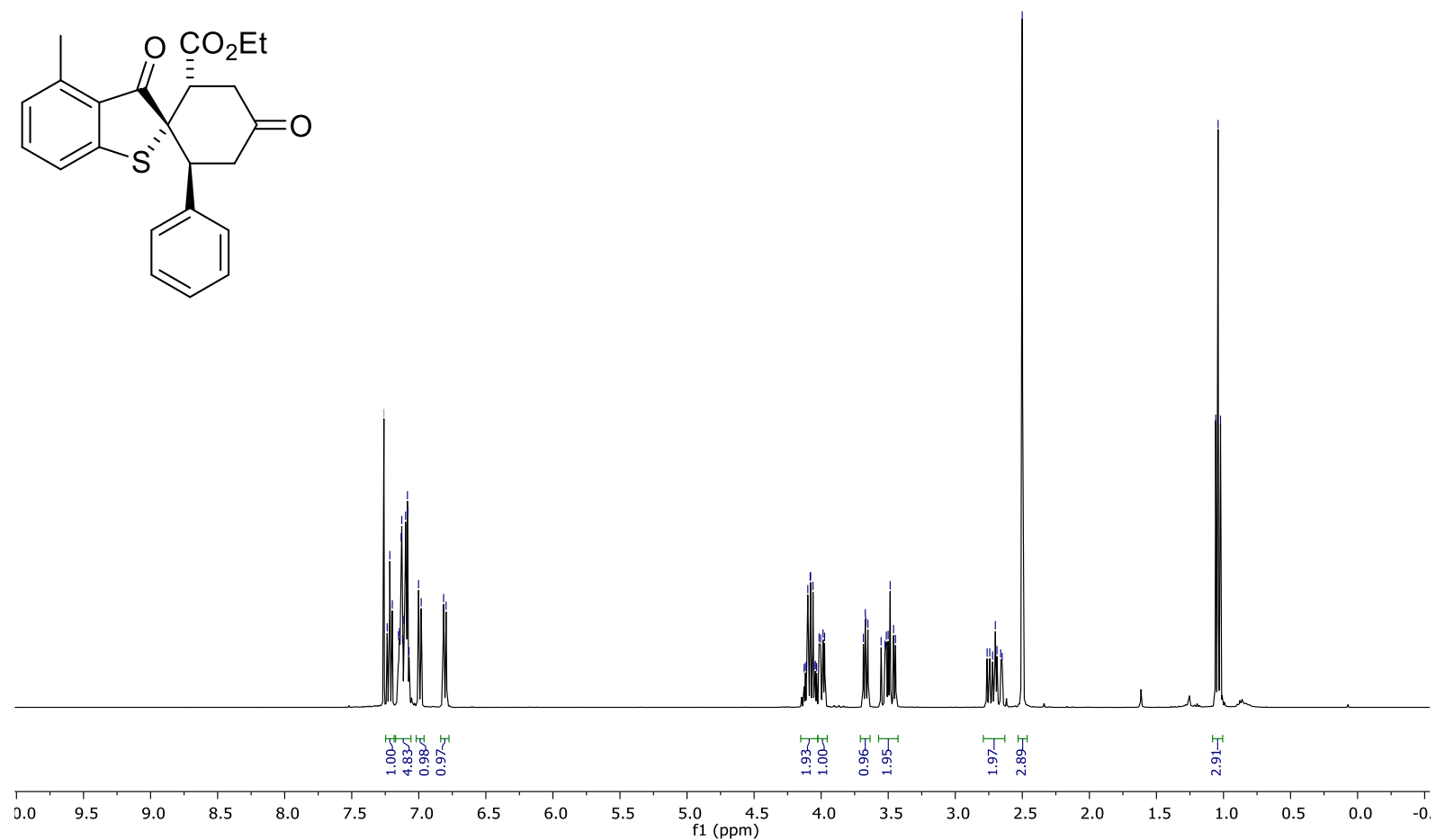

$400 \mathrm{MHz}{ }^{1} \mathrm{H}$ NMR of $\mathbf{3 j a}$ in $\mathrm{CDCl}_{3}$.<smiles>CCOC(=O)[C@@]12CC(=O)C[C@@H](c3ccccc3)[C@@]1(C(=O)OCC)Sc1cccc(C)c12</smiles>

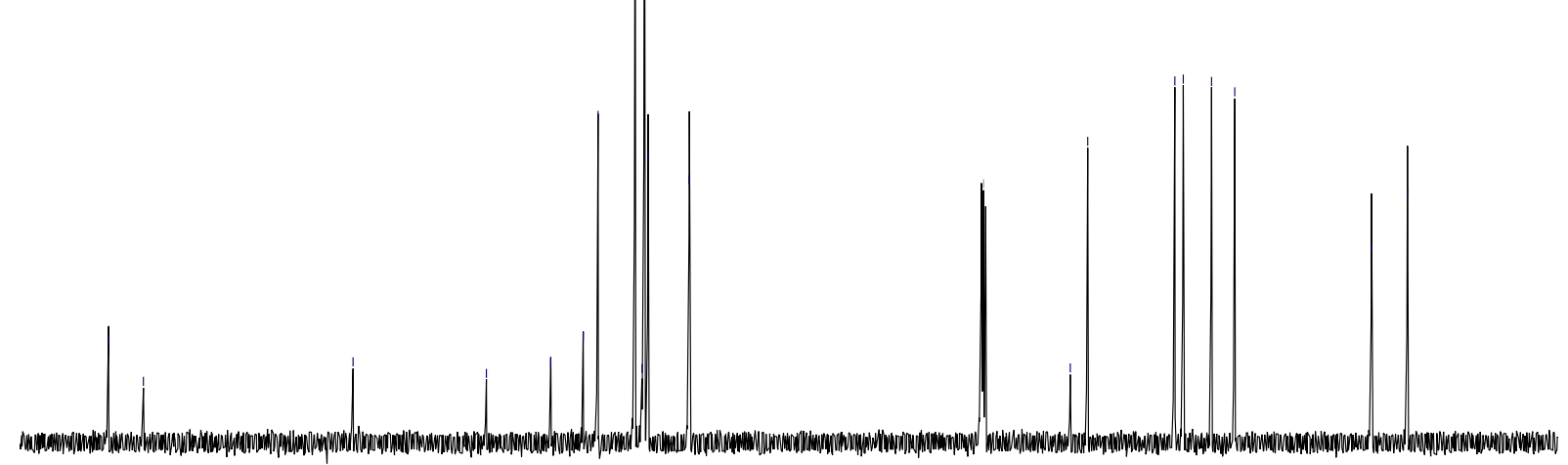

$\begin{array}{lllllllllllllllllllllllll}120 & 210 & 200 & 190 & 180 & 170 & 160 & 150 & 140 & 130 & 120 & \begin{array}{l}110 \\ \mathrm{f}(\mathrm{ppm})\end{array} & 100 & 90 & 80 & 70 & 60 & 50 & 40 & 30 & 20 & 10 & 0\end{array}$ $101 \mathrm{MHz}{ }^{13} \mathrm{NMR}$ of $\mathbf{3 j a}$ in $\mathrm{CDCl}_{3}$. 


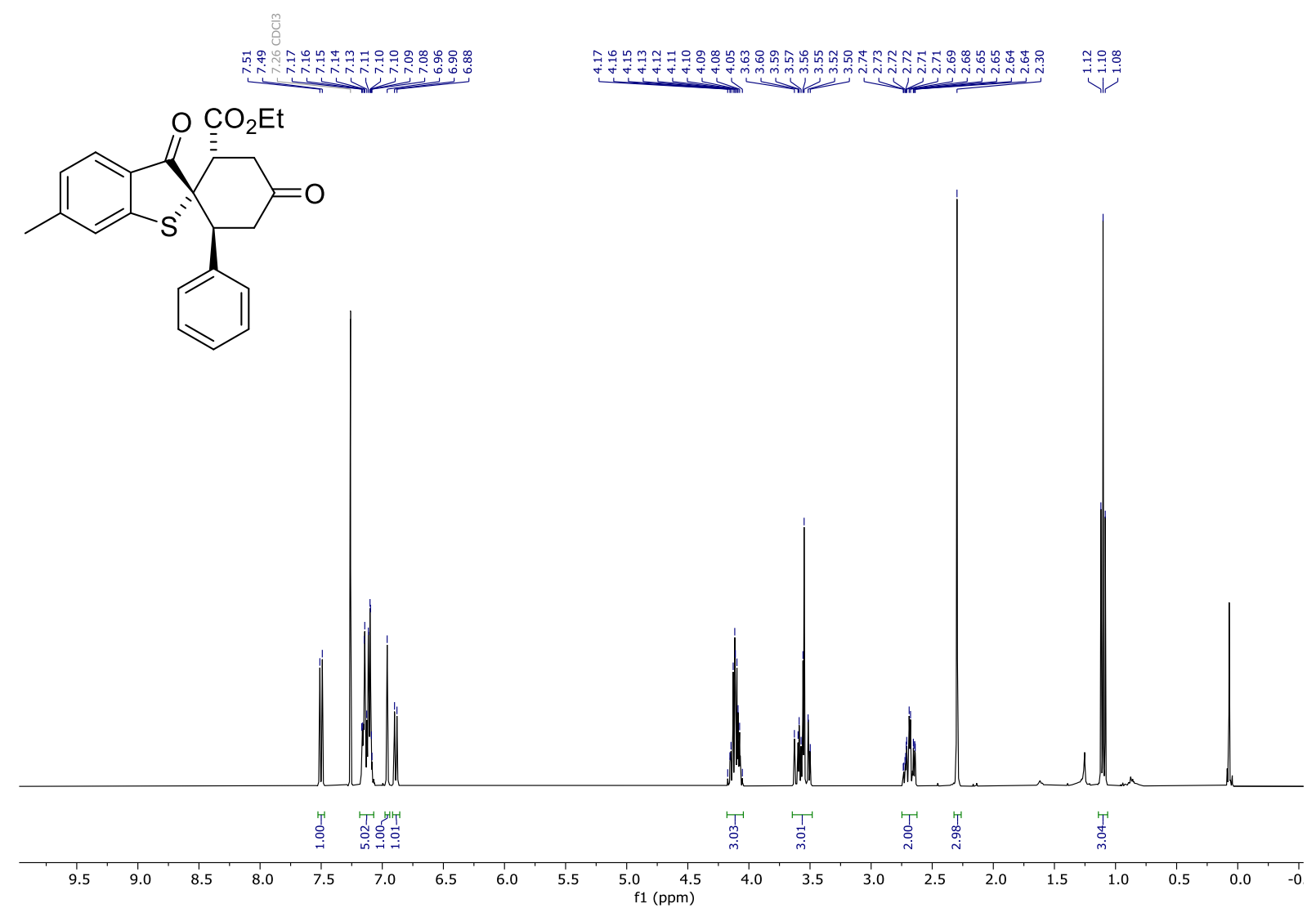

$400 \mathrm{MHz}{ }^{1} \mathrm{H}$ NMR of $\mathbf{3 k a}$ in $\mathrm{CDCl}_{3}$.

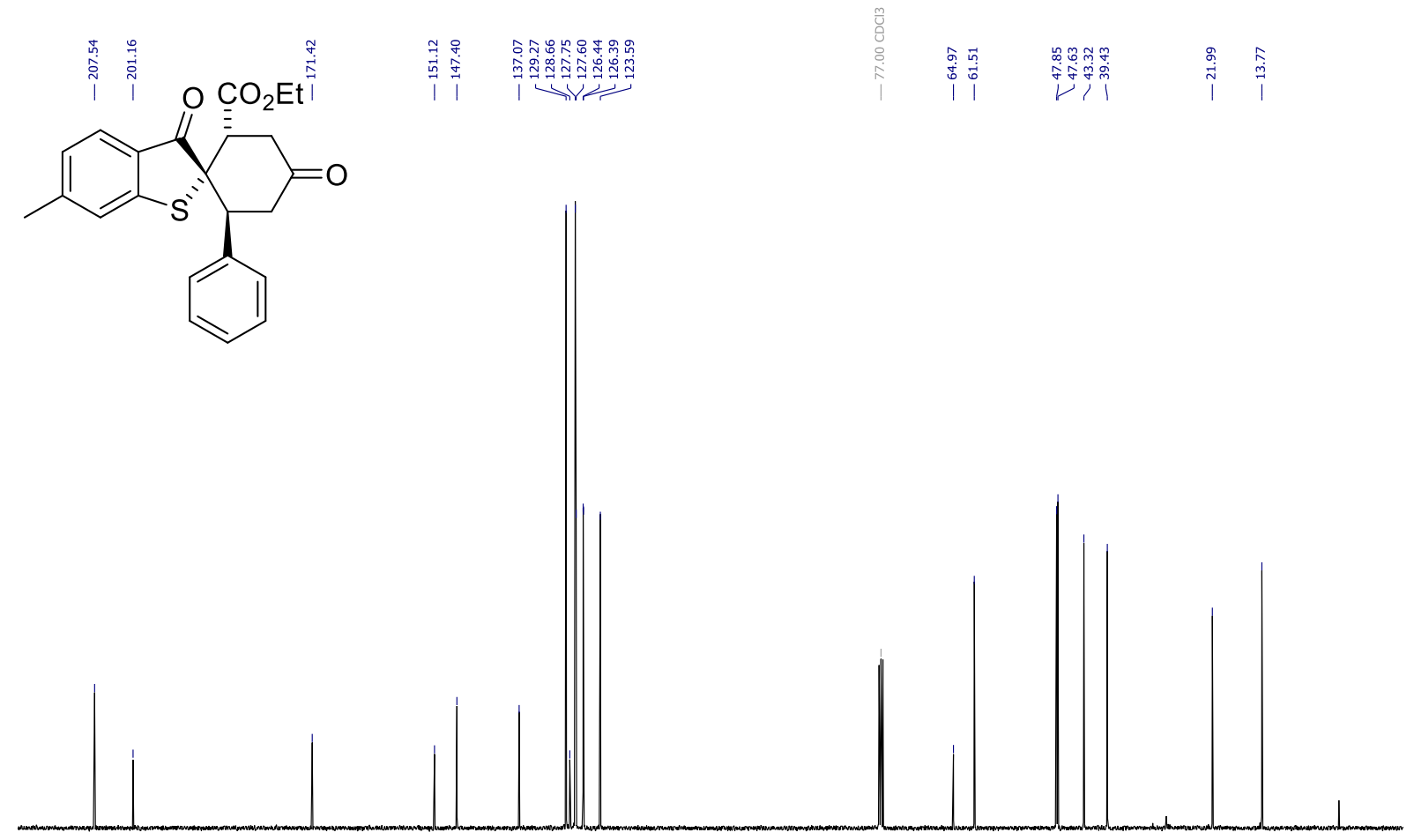

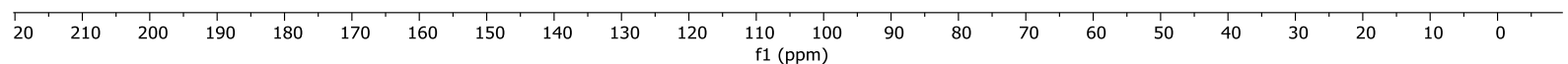
$101 \mathrm{MHz}{ }^{13} \mathrm{NMR}$ of $\mathbf{3 k a}$ in $\mathrm{CDCl}_{3}$. 


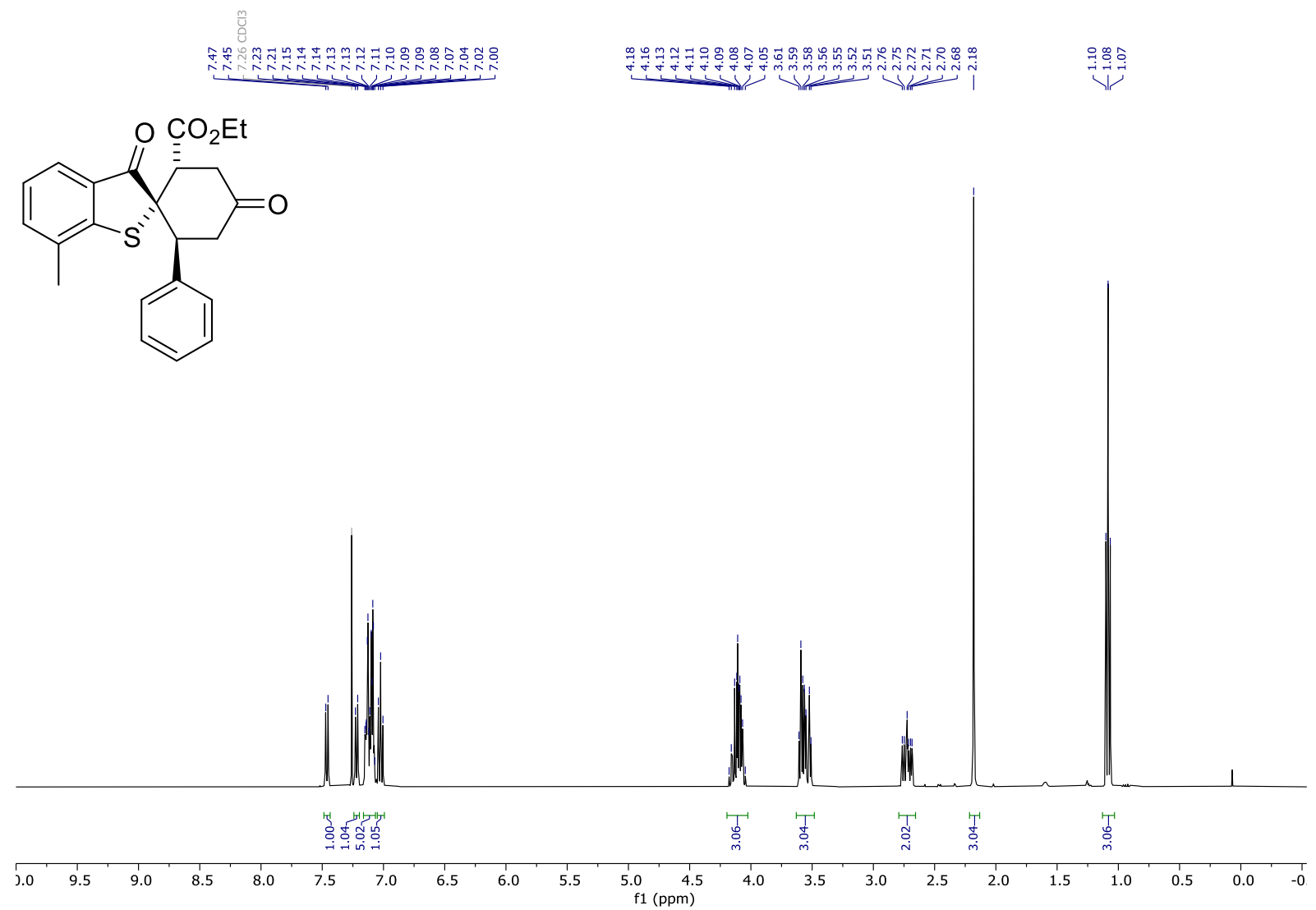

$400 \mathrm{MHz}{ }^{1} \mathrm{H}$ NMR of $3 \mathbf{l a}$ in $\mathrm{CDCl}_{3}$.

|

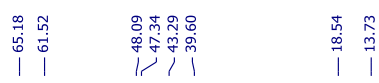<smiles>CCOC(=O)[C@@]12Sc3c(C)cccc3C(=O)[C@]1(c1ccccc1)CC(=O)C[C@H]2C</smiles>

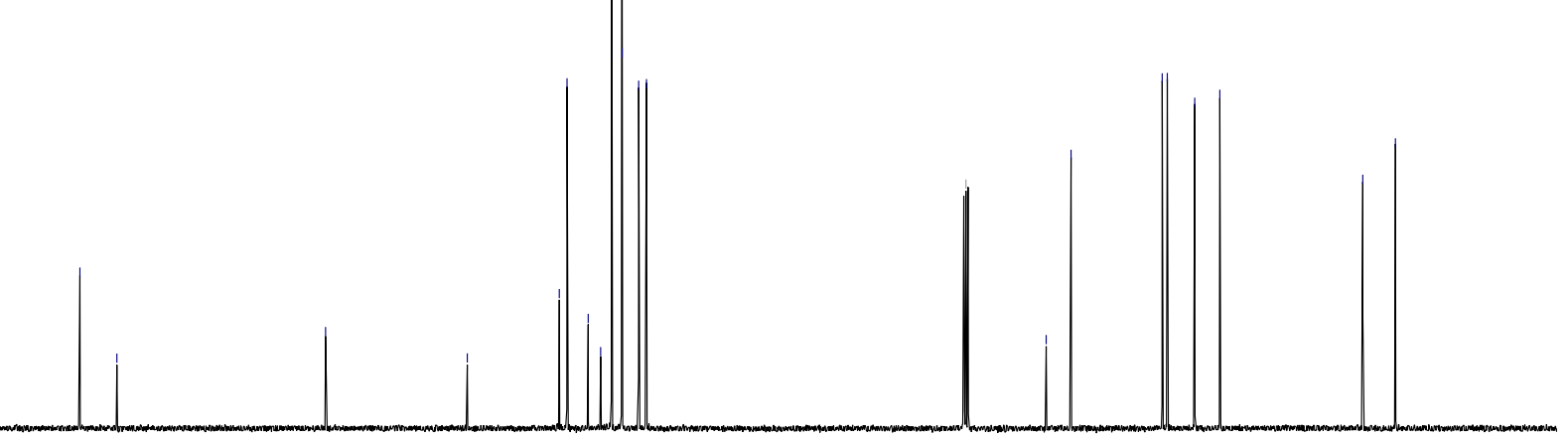

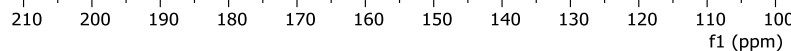

$101 \mathrm{MHz}{ }^{13} \mathrm{NMR}$ of $3 \mathbf{3 l a}$ in $\mathrm{CDCl}_{3}$. 


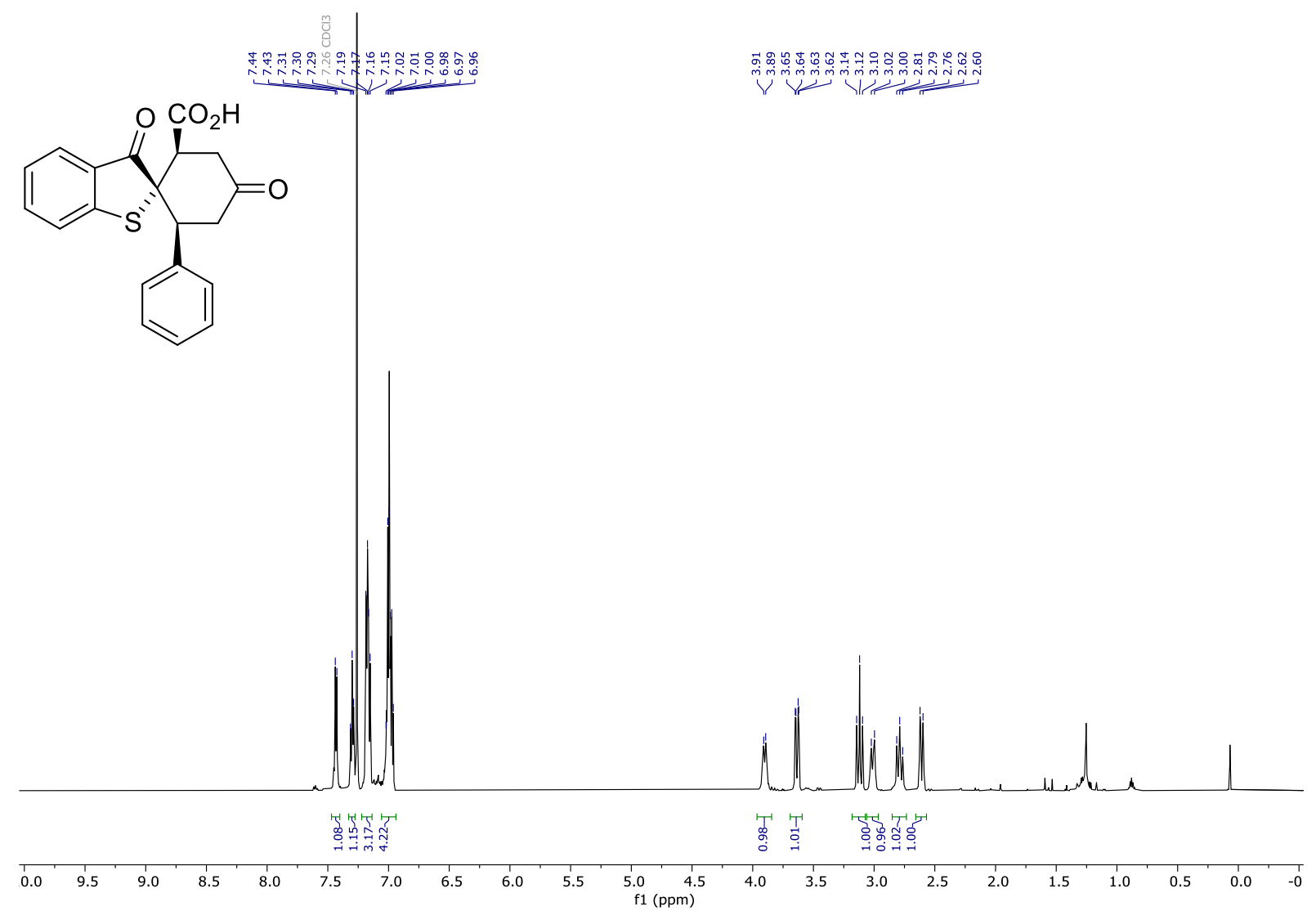

$600 \mathrm{MHz}{ }^{1} \mathrm{H}$ NMR of 4', aa in $\mathrm{CDCl}_{3}$.

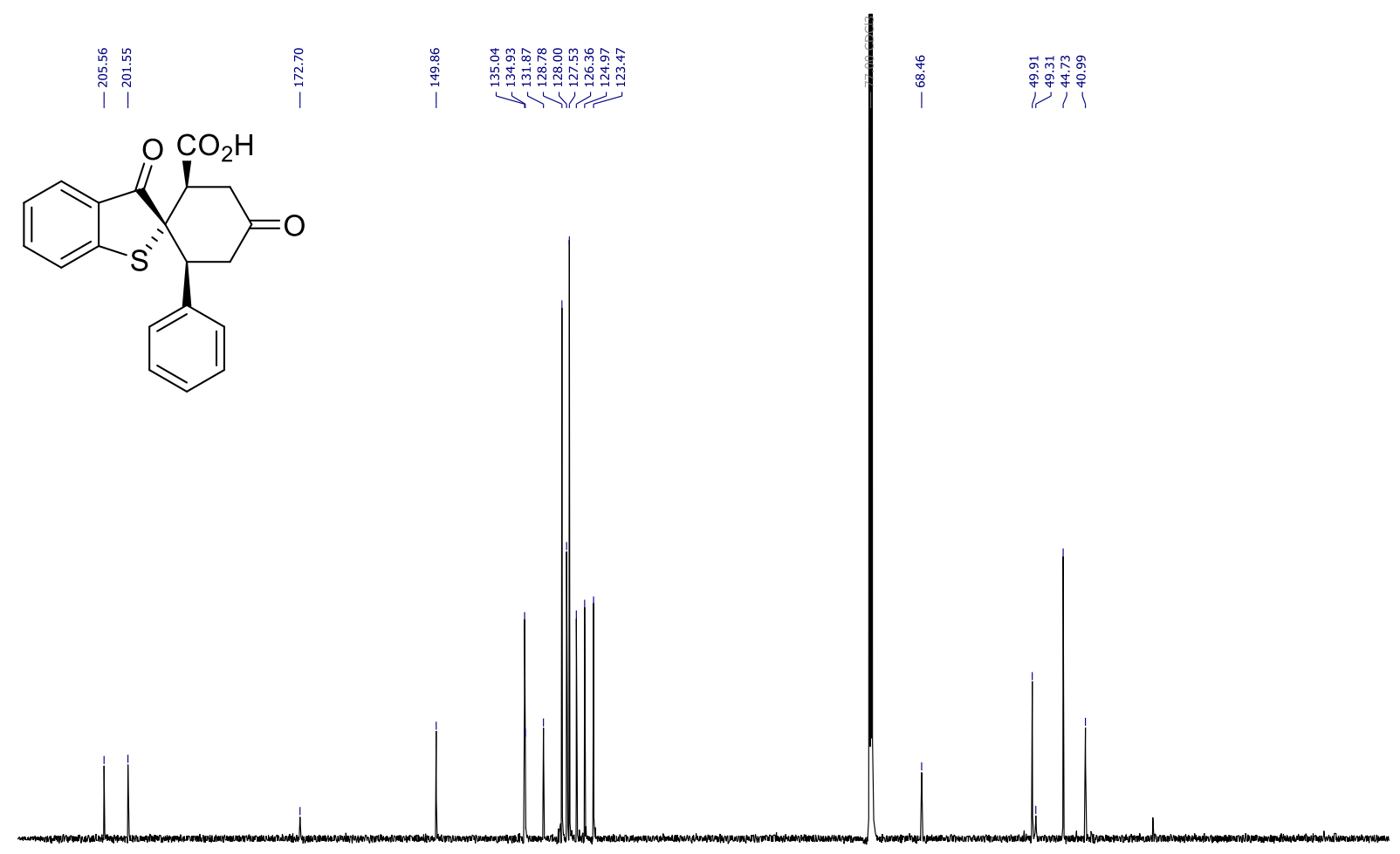

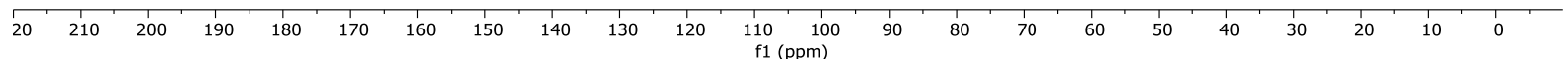

$151 \mathrm{MHz}{ }^{13} \mathrm{NMR}$ of 4 ', aa in $\mathrm{CDCl}_{3}$. 


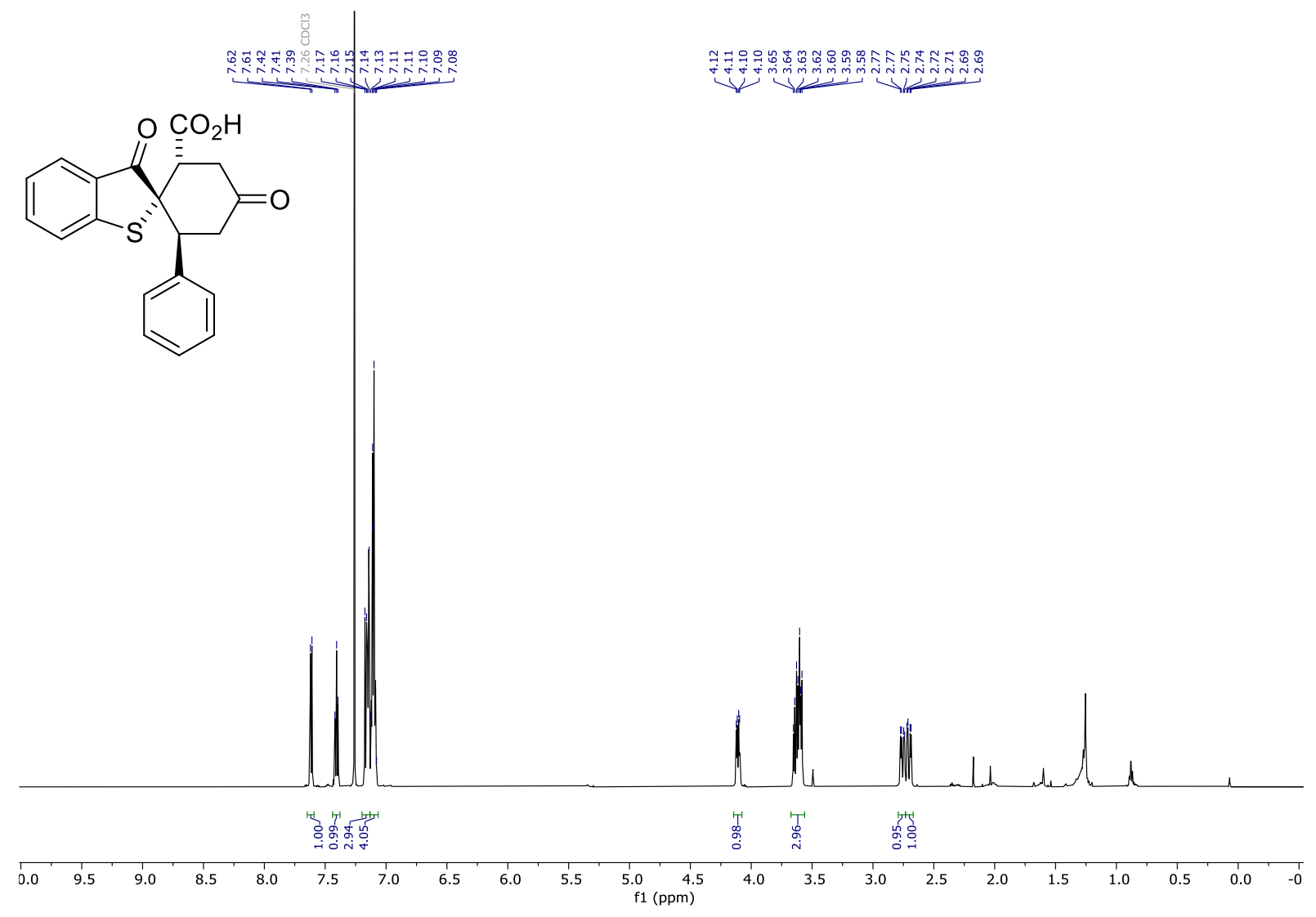

$600 \mathrm{MHz}{ }^{1} \mathrm{H} \mathrm{NMR}$ of $\mathbf{4 a a}$ in $\mathrm{CDCl}_{3}$.

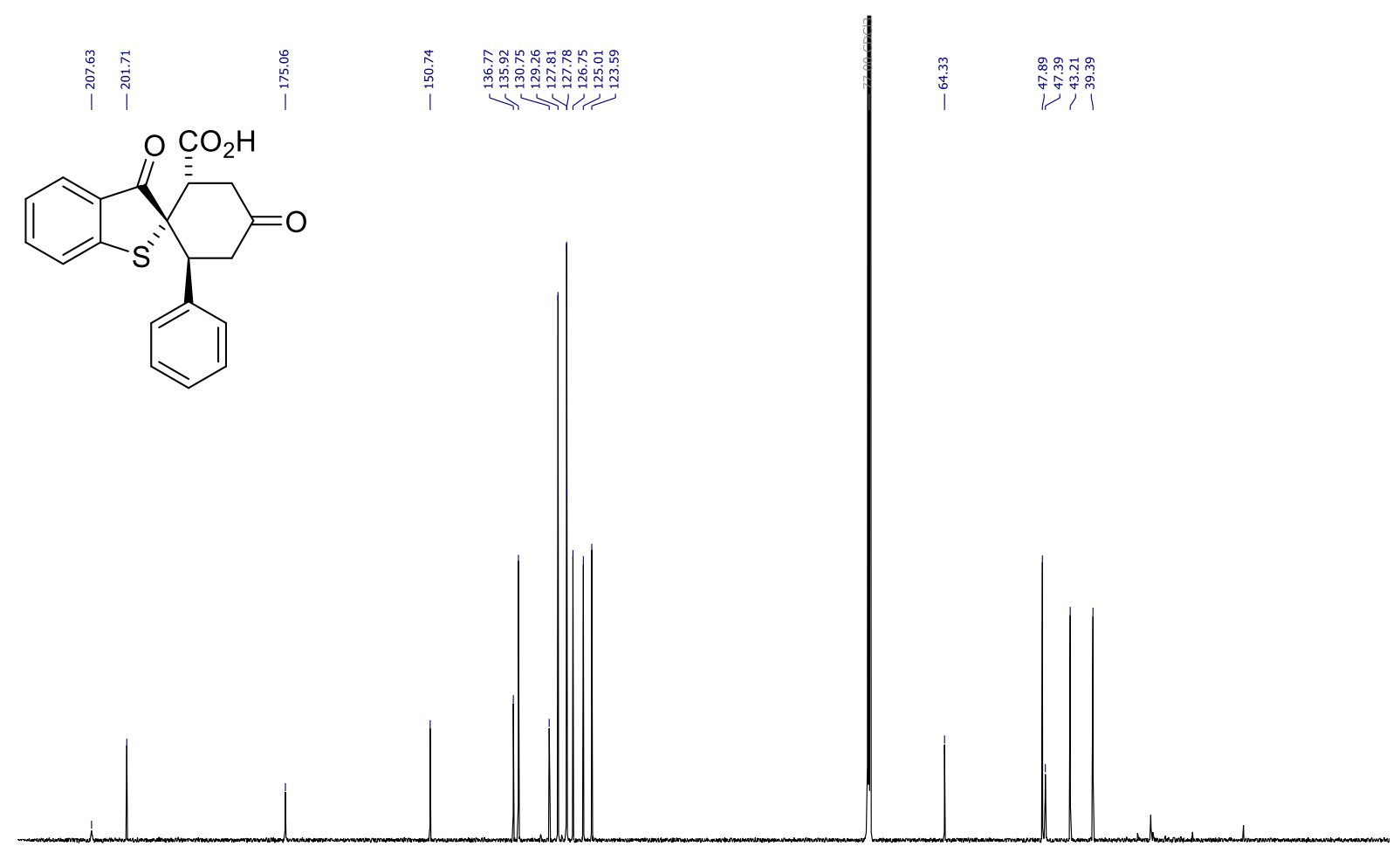

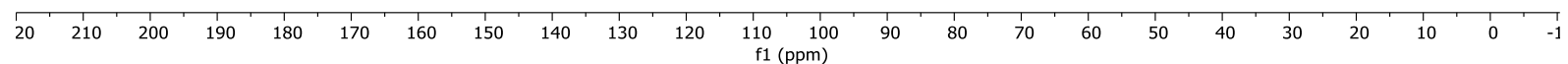

$151 \mathrm{MHz}{ }^{13} \mathrm{NMR}$ of $\mathbf{4 a a}$ in $\mathrm{CDCl}_{3}$. 


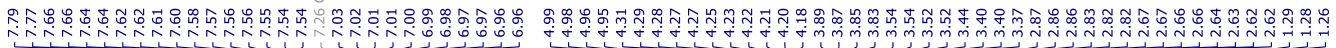

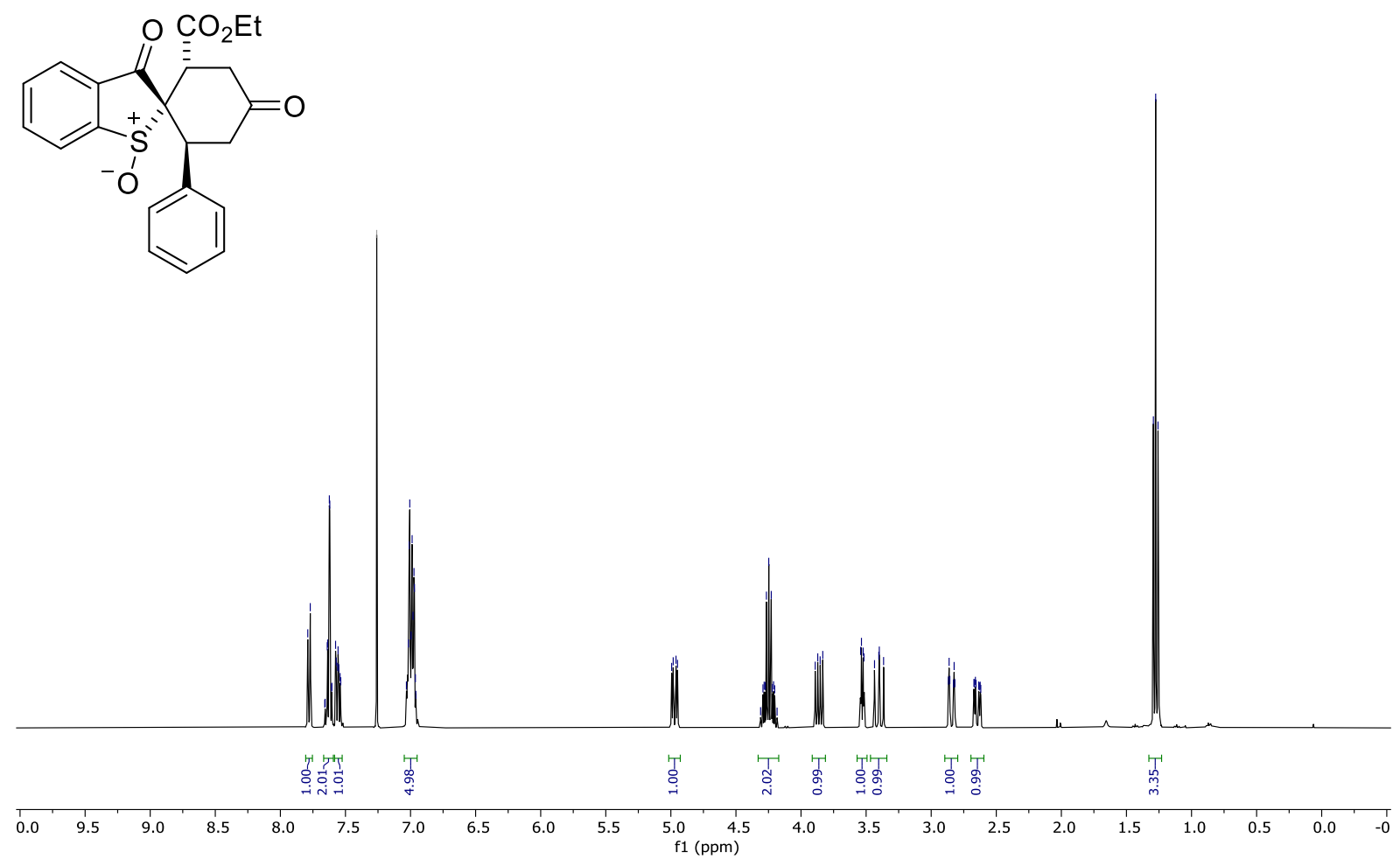

$400 \mathrm{MHz}{ }^{1} \mathrm{H}$ NMR of $\mathbf{5 a}$ in $\mathrm{CDCl}_{3}$.

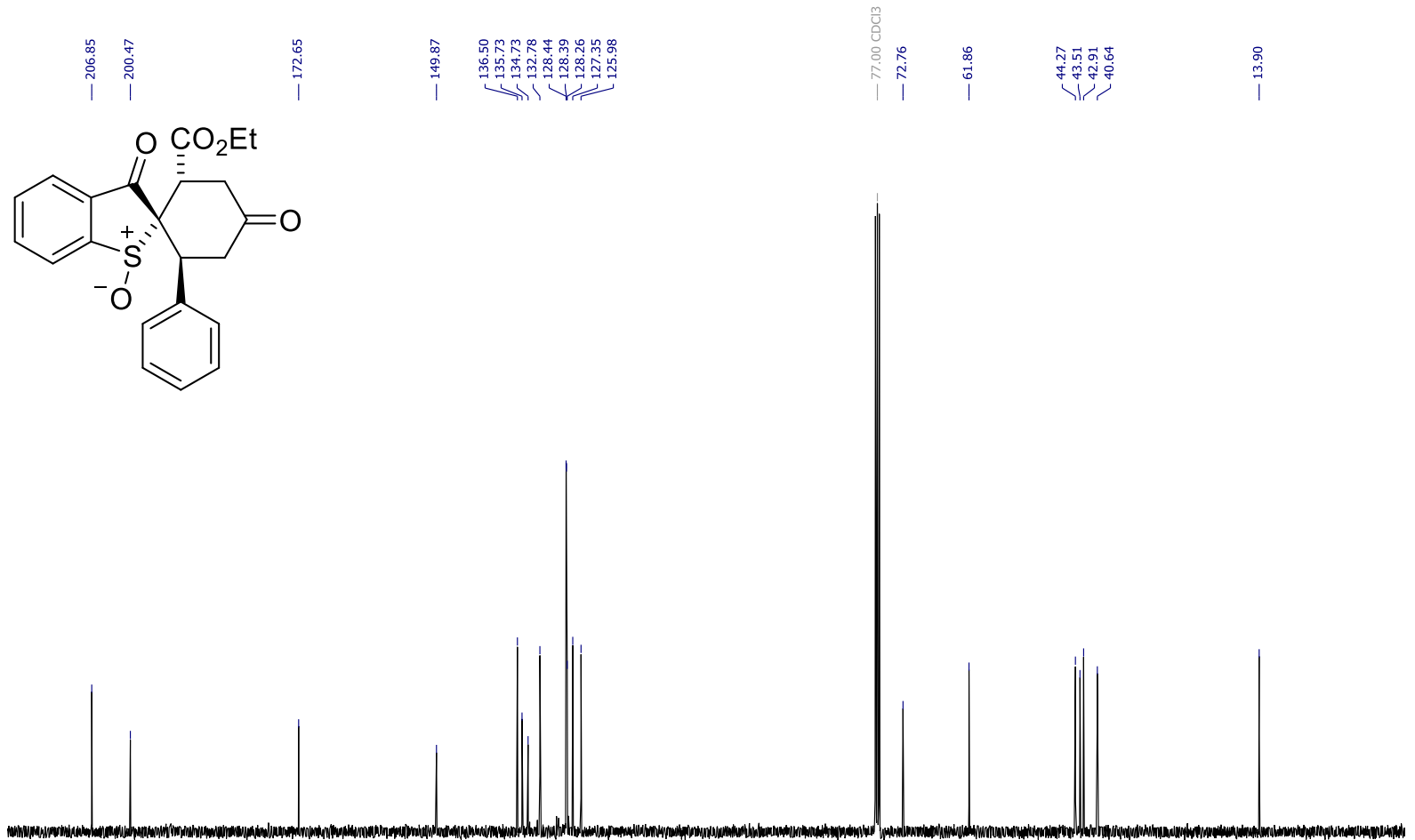

$\begin{array}{lllllllllllllllllllllllllllllll}1 & 10 & 210 & 200 & 190 & 180 & 170 & 160 & 150 & 140 & 130 & 120 & \begin{array}{c}110 \\ f 1(\mathrm{ppm})\end{array} & 90 & 80 & 70 & 60 & 50 & 40 & 30 & 20 & 10 & 0 & -1\end{array}$ $101 \mathrm{MHz}{ }^{13} \mathrm{NMR}$ of $\mathbf{5 a}$ in $\mathrm{CDCl}_{3}$. 


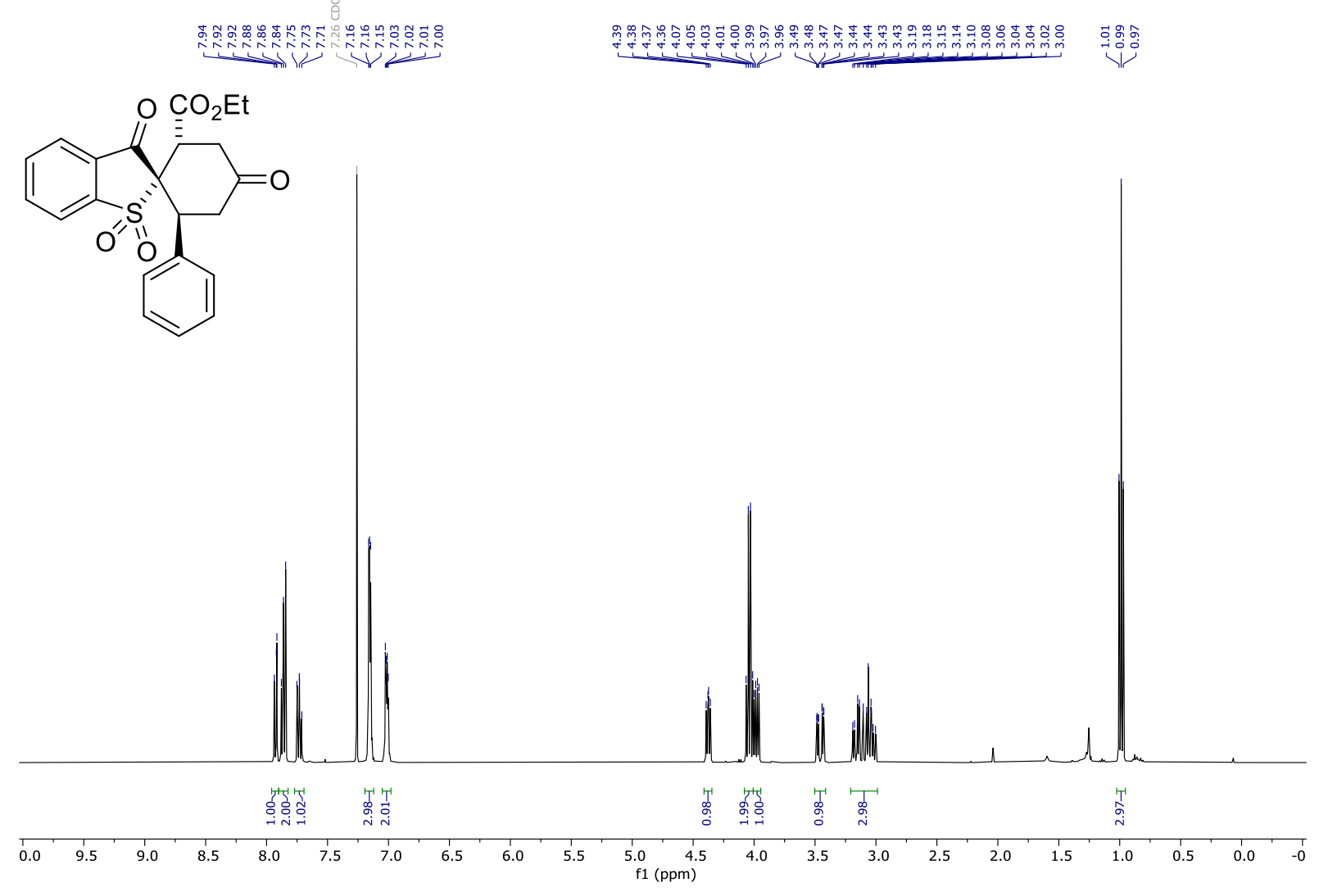

$400 \mathrm{MHz}{ }^{1} \mathrm{H}$ NMR of $\mathbf{6 a}$ in $\mathrm{CDCl}_{3}$.

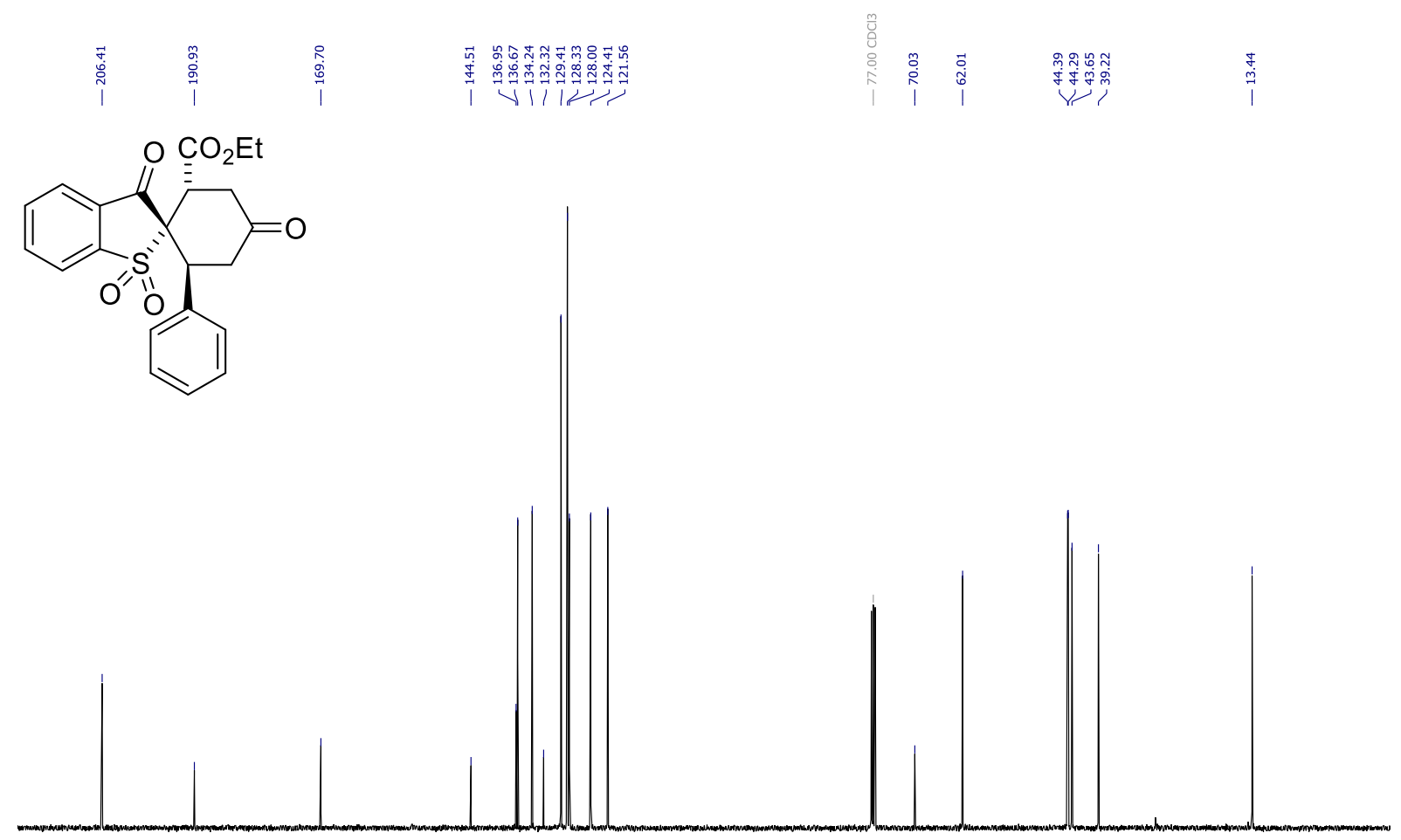

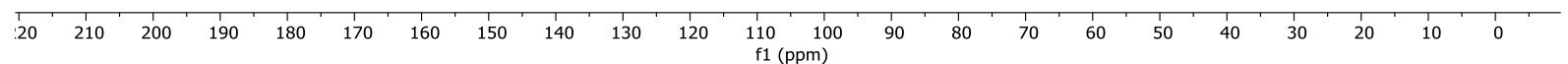
$101 \mathrm{MHz}{ }^{13} \mathrm{NMR}$ of $\mathbf{6 a}$ in $\mathrm{CDCl}_{3}$. 


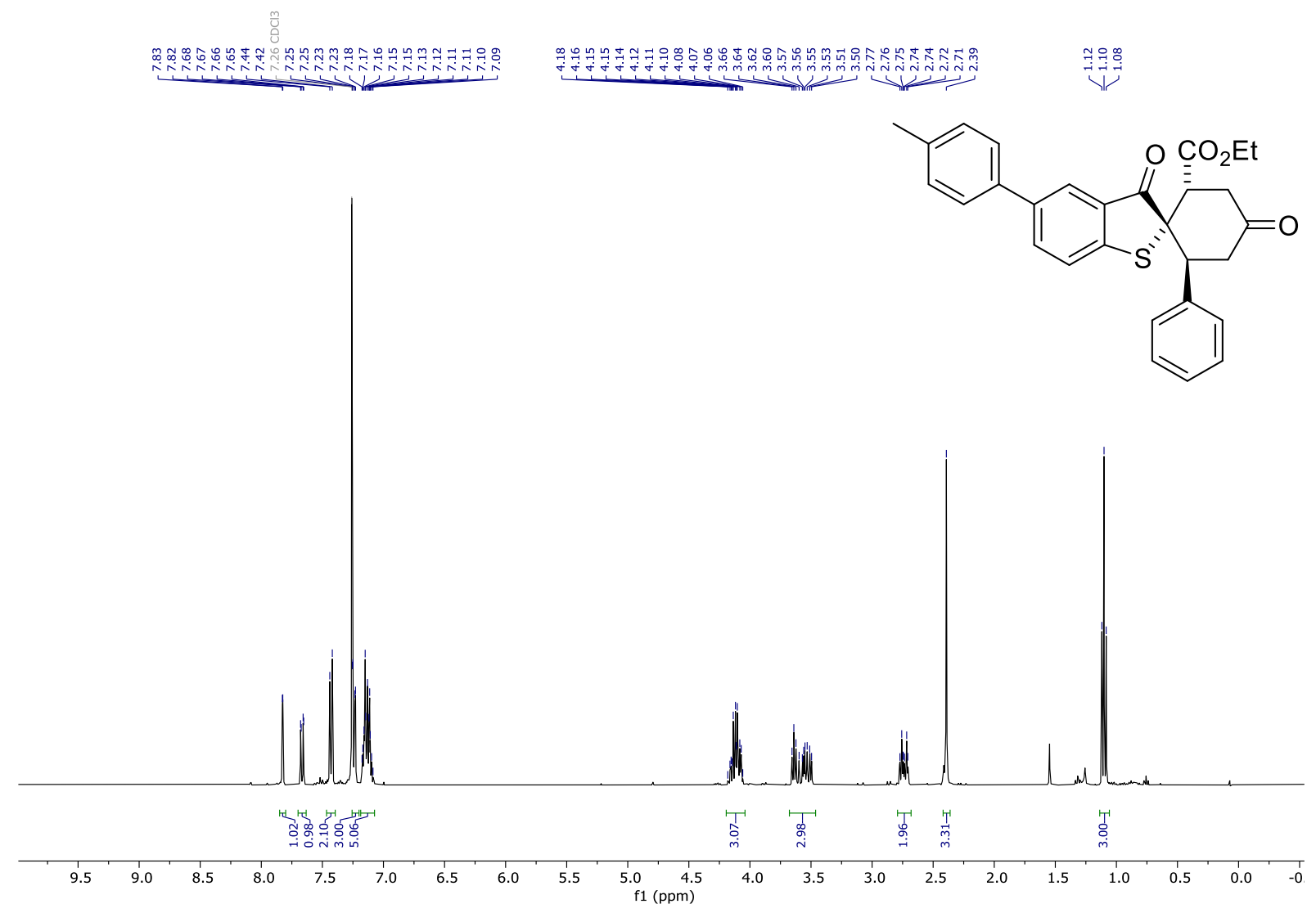

$400 \mathrm{MHz}{ }^{1} \mathrm{H}$ NMR of $\mathbf{7 a}$ in $\mathrm{CDCl}_{3}$.

๖̊

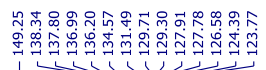
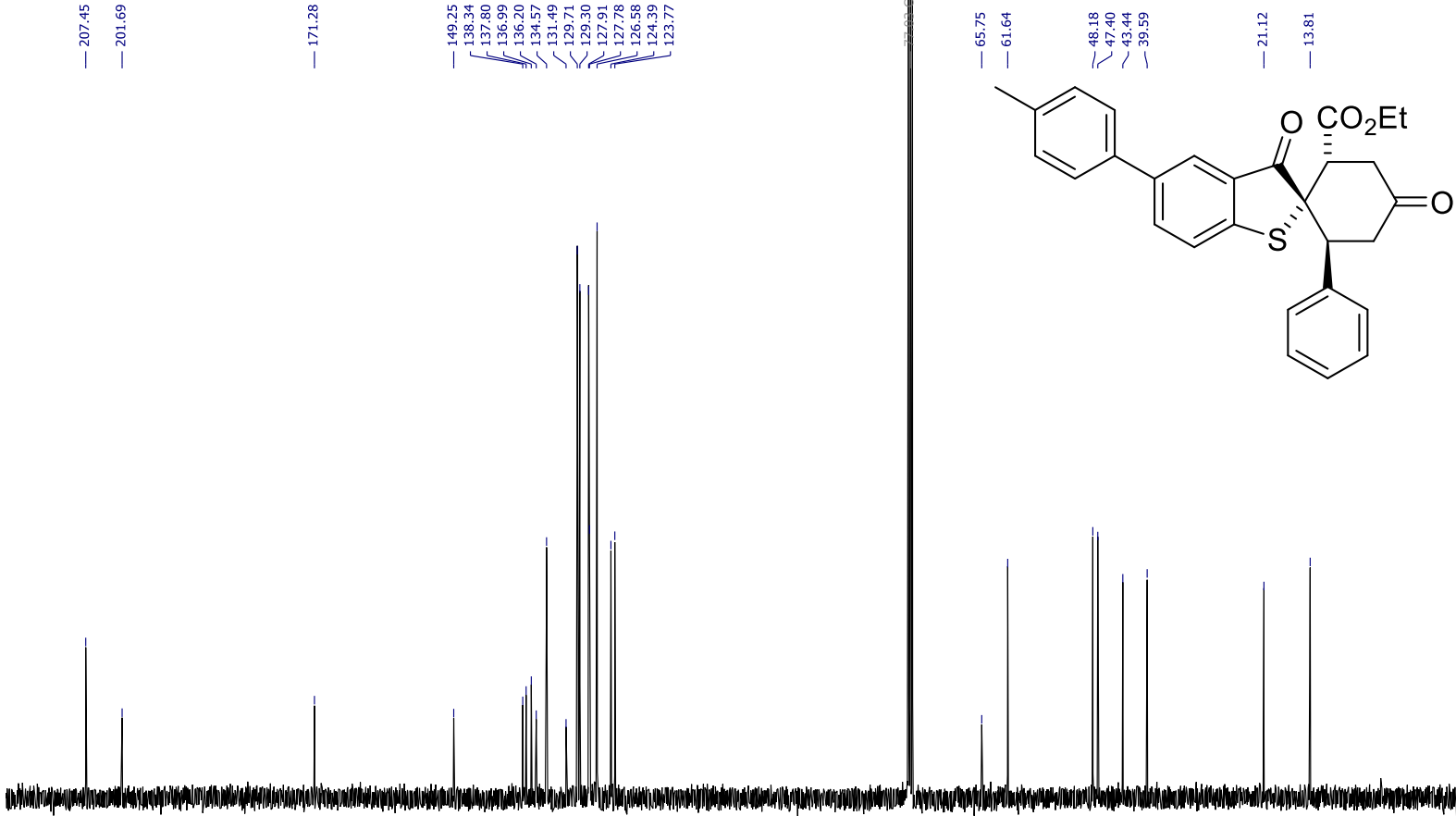

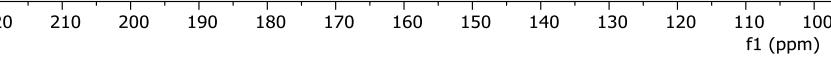

$101 \mathrm{MHz}{ }^{13} \mathrm{NMR}$ of $\mathbf{7 a}$ in $\mathrm{CDCl}_{3}$. 


\section{Chiral HPLC chromatograms}
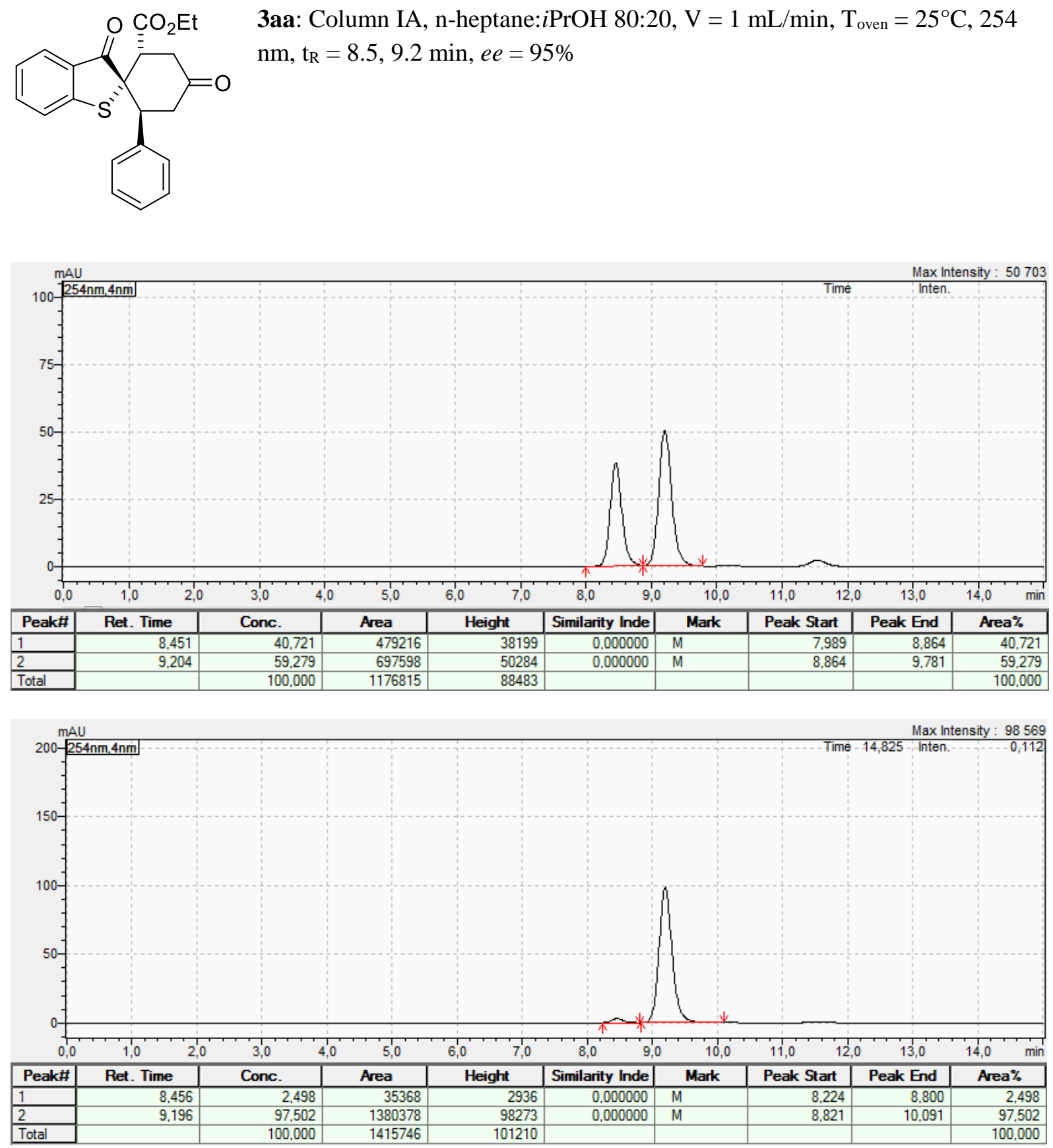


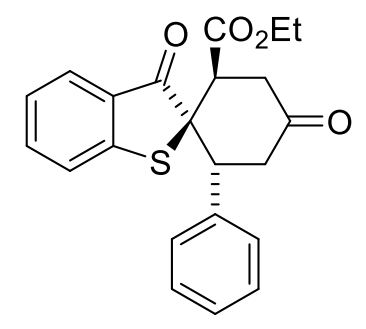

ent-3aa: Column IA, n-heptane: $i \mathrm{PrOH} 80: 20, \mathrm{~V}=1 \mathrm{~mL} / \mathrm{min}, \mathrm{T}_{\text {oven }}=25^{\circ} \mathrm{C}$, $254 \mathrm{~nm}, \mathrm{t}_{\mathrm{R}}=8.5,9.2 \mathrm{~min}, e e=-87 \%$
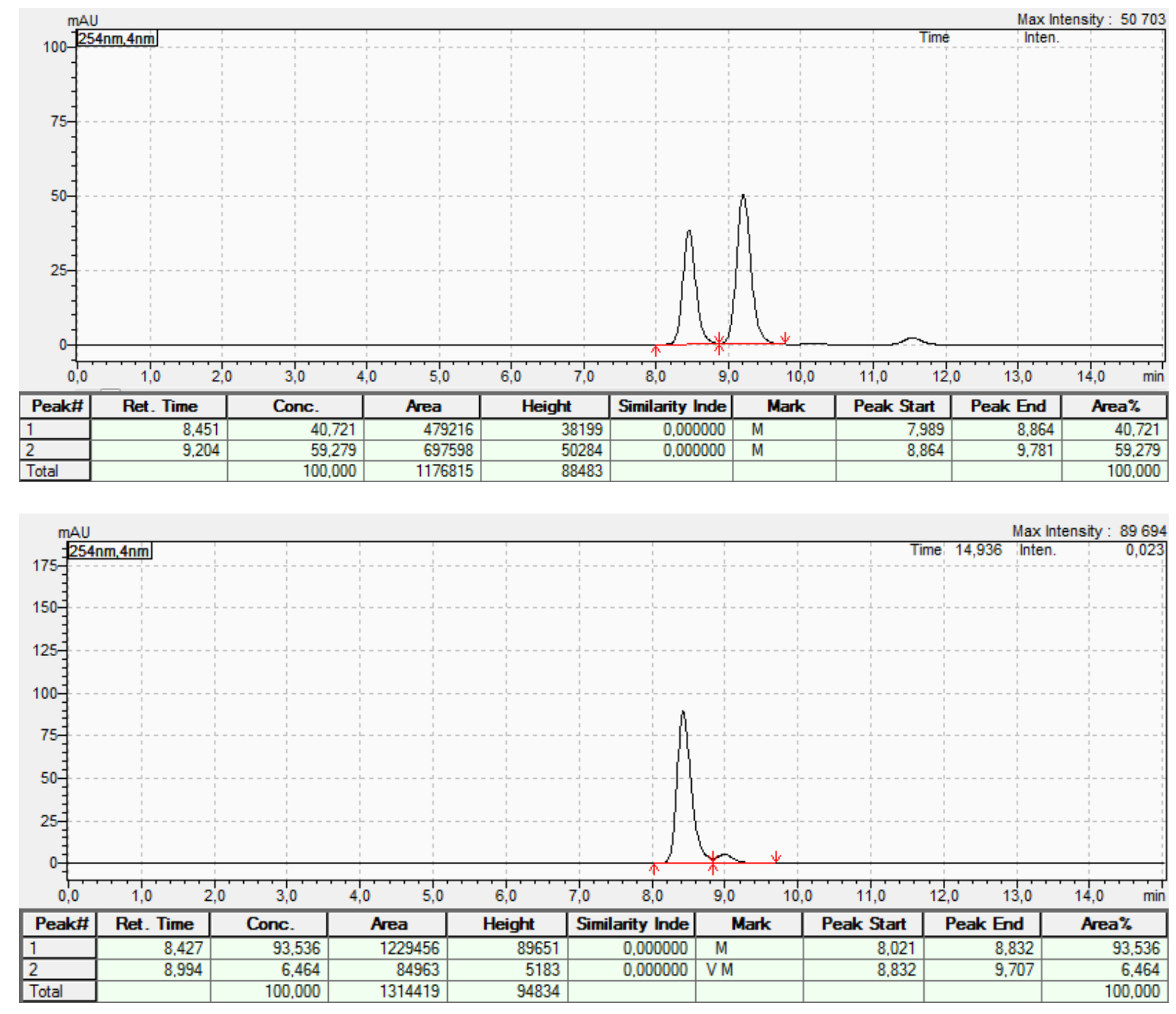


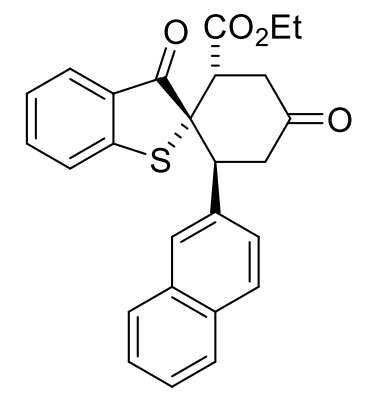

3ab: Column IA, n-heptane: $\mathrm{PrOH} 80: 20, \mathrm{~V}=1 \mathrm{~mL} / \mathrm{min}, \mathrm{T}_{\text {oven }}=25^{\circ} \mathrm{C}, 254$ $\mathrm{nm}, \mathrm{t}_{\mathrm{R}}=11.1,16.3 \mathrm{~min}, e e=95 \%$
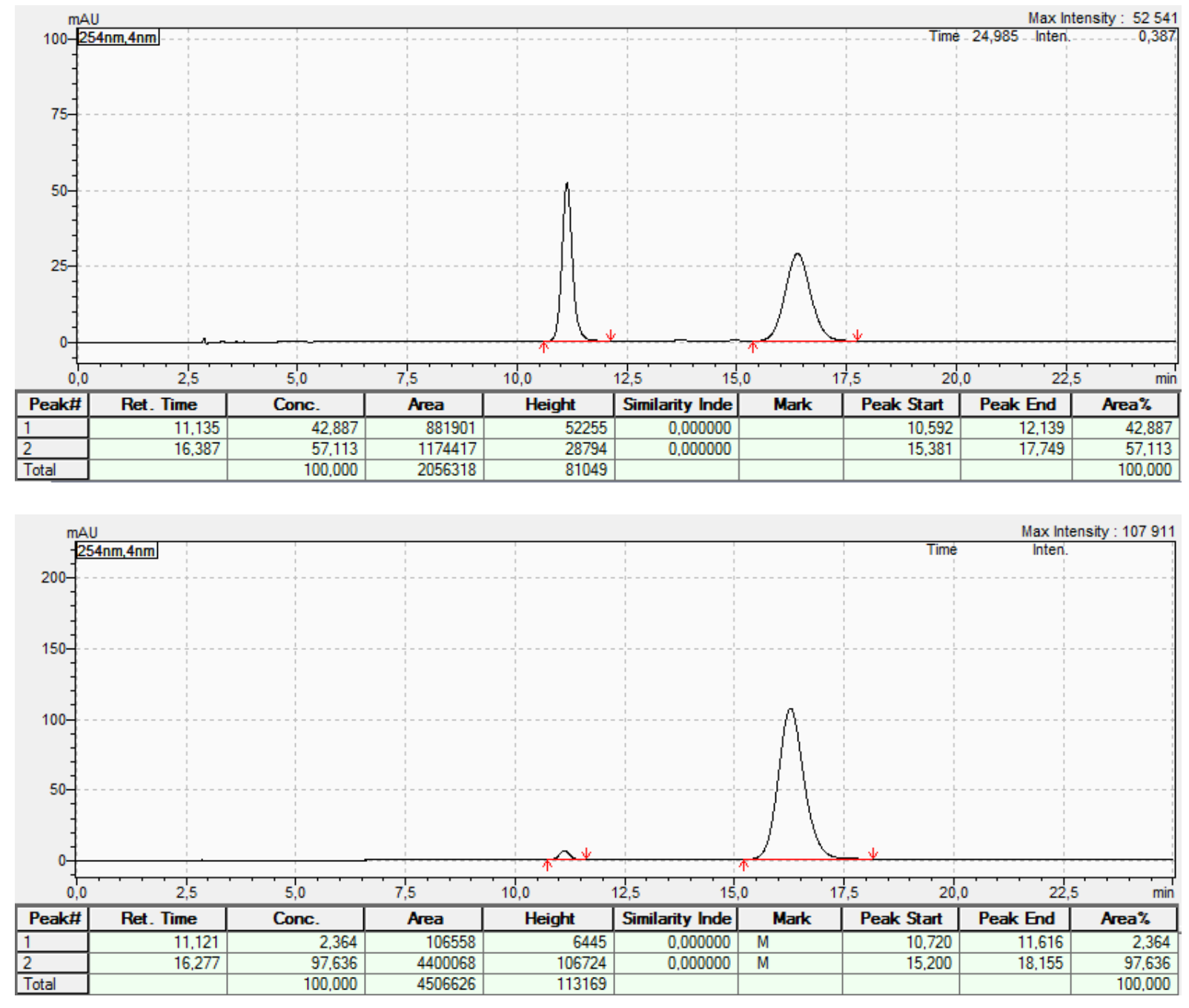


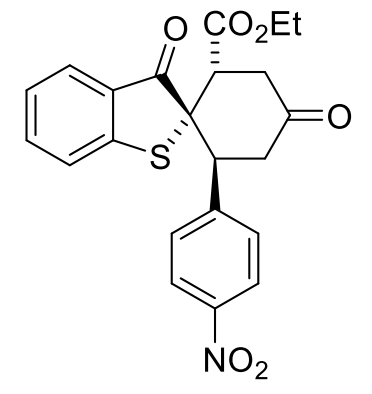

3ac: Column IC, n-heptane: $i \operatorname{PrOH} 80: 20, \mathrm{~V}=1 \mathrm{~mL} / \mathrm{min}, \mathrm{T}_{\text {oven }}=25^{\circ} \mathrm{C}, 254$ $\mathrm{nm}, \mathrm{t}_{\mathrm{R}}=47.5,55.4 \mathrm{~min}, e e=86 \%$
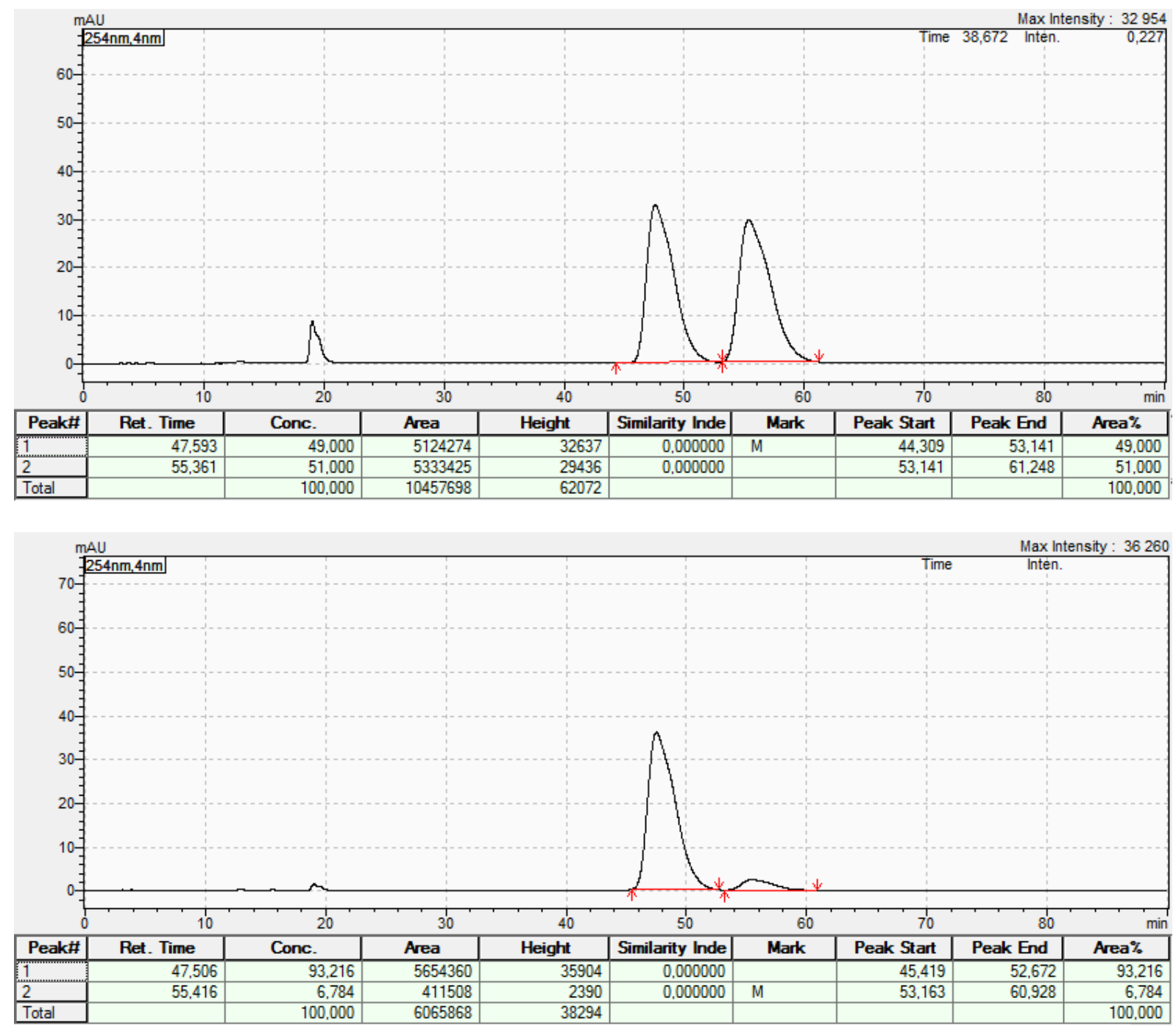
<smiles></smiles>

3ad: Column IA, n-heptane: $i \operatorname{PrOH} 80: 20, \mathrm{~V}=1 \mathrm{~mL} / \mathrm{min}, \mathrm{T}_{\text {oven }}=25^{\circ} \mathrm{C}, 240$ $\mathrm{nm}, \mathrm{t}_{\mathrm{R}}=14.5,16.0 \mathrm{~min}, e e=92 \%$
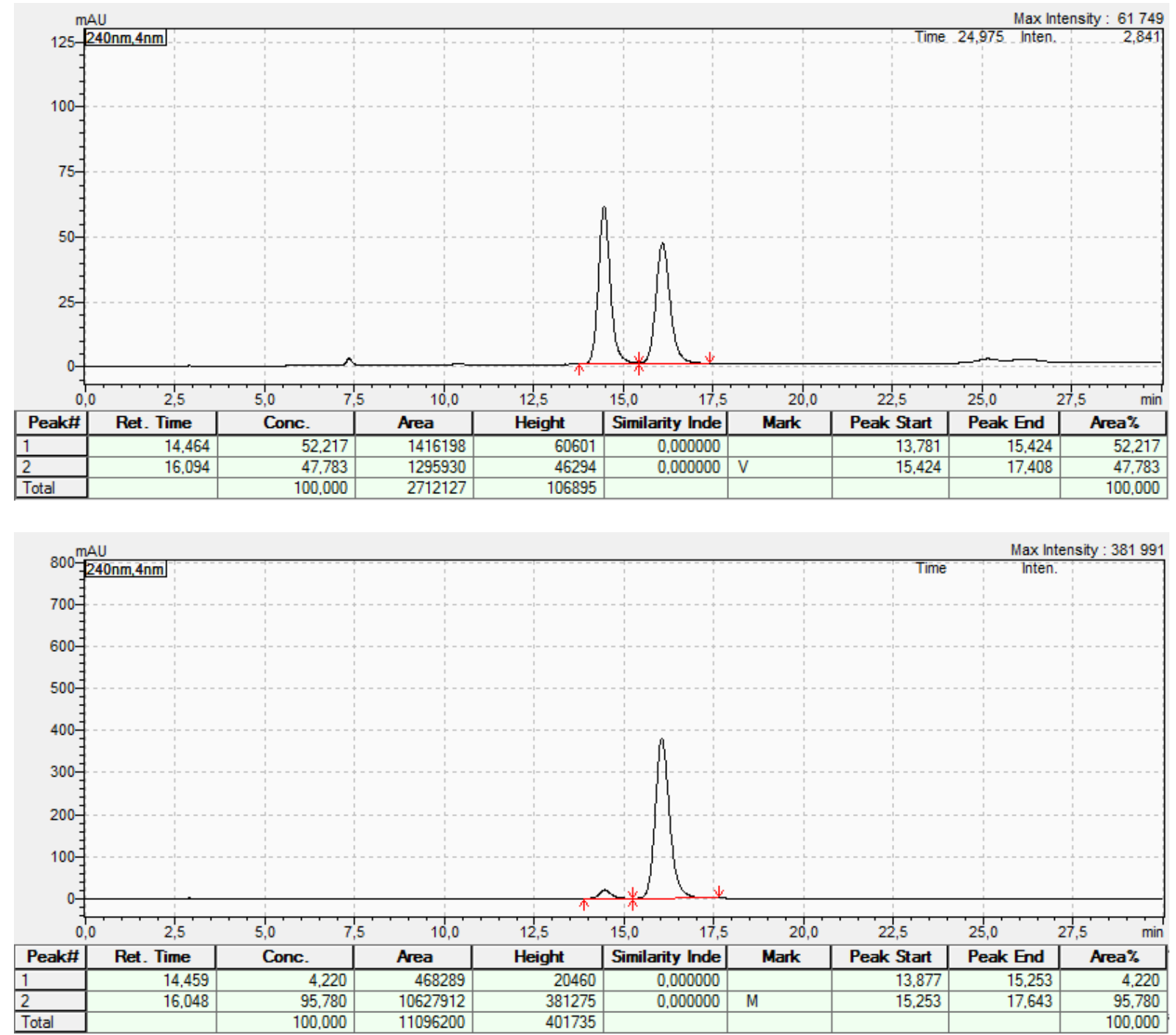
<smiles>CCOC(=O)C1CC(=O)CC(c2ccccc2[N+](=O)[O-])C12Sc1ccccc1C2=O</smiles>

3ae: Column IA, n-heptane: $i \operatorname{PrOH} 80: 20, \mathrm{~V}=1 \mathrm{~mL} / \mathrm{min}, \mathrm{T}_{\text {oven }}=25^{\circ} \mathrm{C}, 240$ $\mathrm{nm}, \mathrm{t}_{\mathrm{R}}=15.9,19.5 \mathrm{~min}, e e=83 \%$
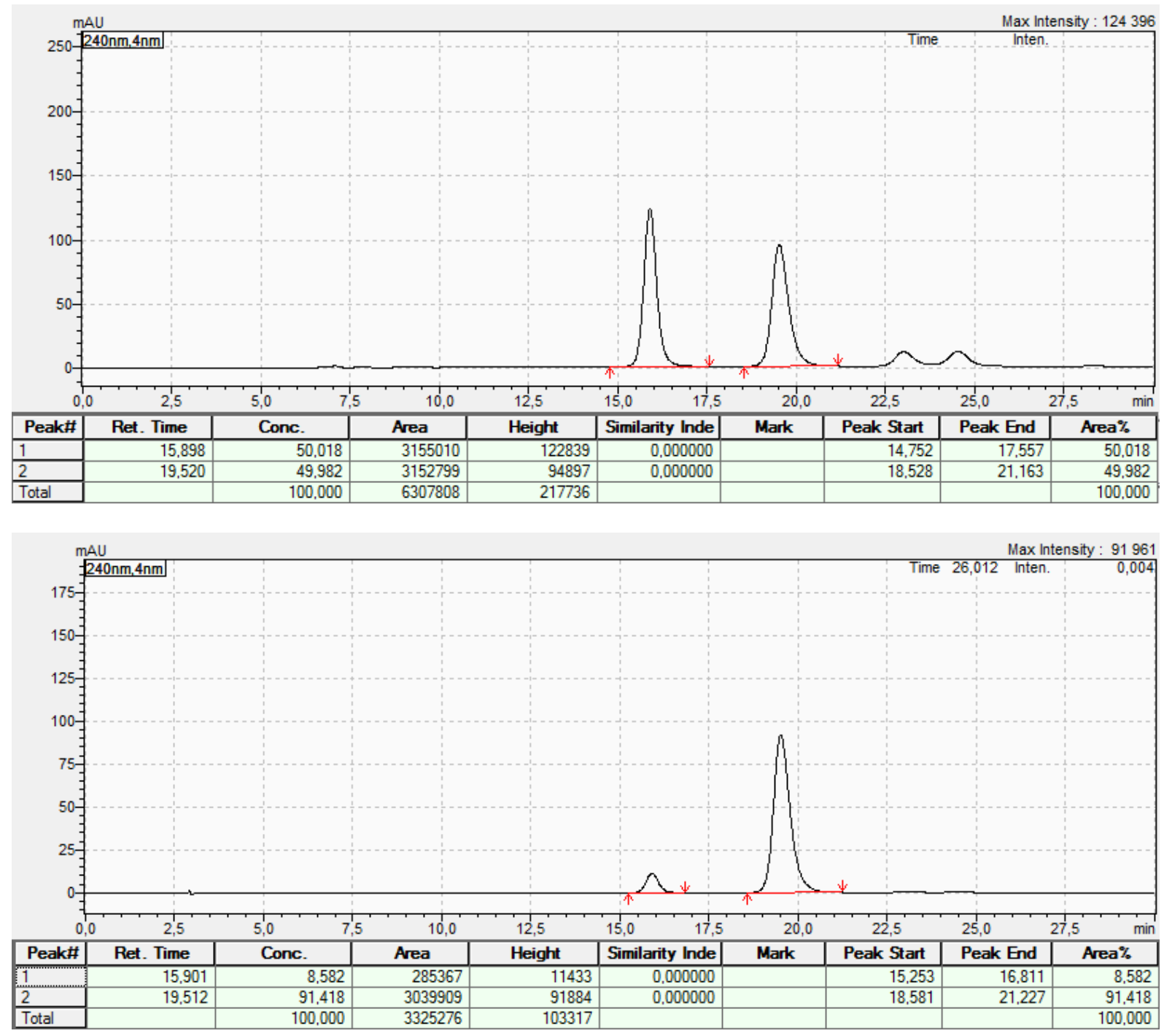
<smiles></smiles>

3af: Column IA, n-heptane: $i \operatorname{PrOH} 90: 10, \mathrm{~V}=1 \mathrm{~mL} / \mathrm{min}, \mathrm{T}_{\text {oven }}=25^{\circ} \mathrm{C}, 240$ $\mathrm{nm}, \mathrm{t}_{\mathrm{R}}=14.8,17.5 \mathrm{~min}, e e=90 \%$
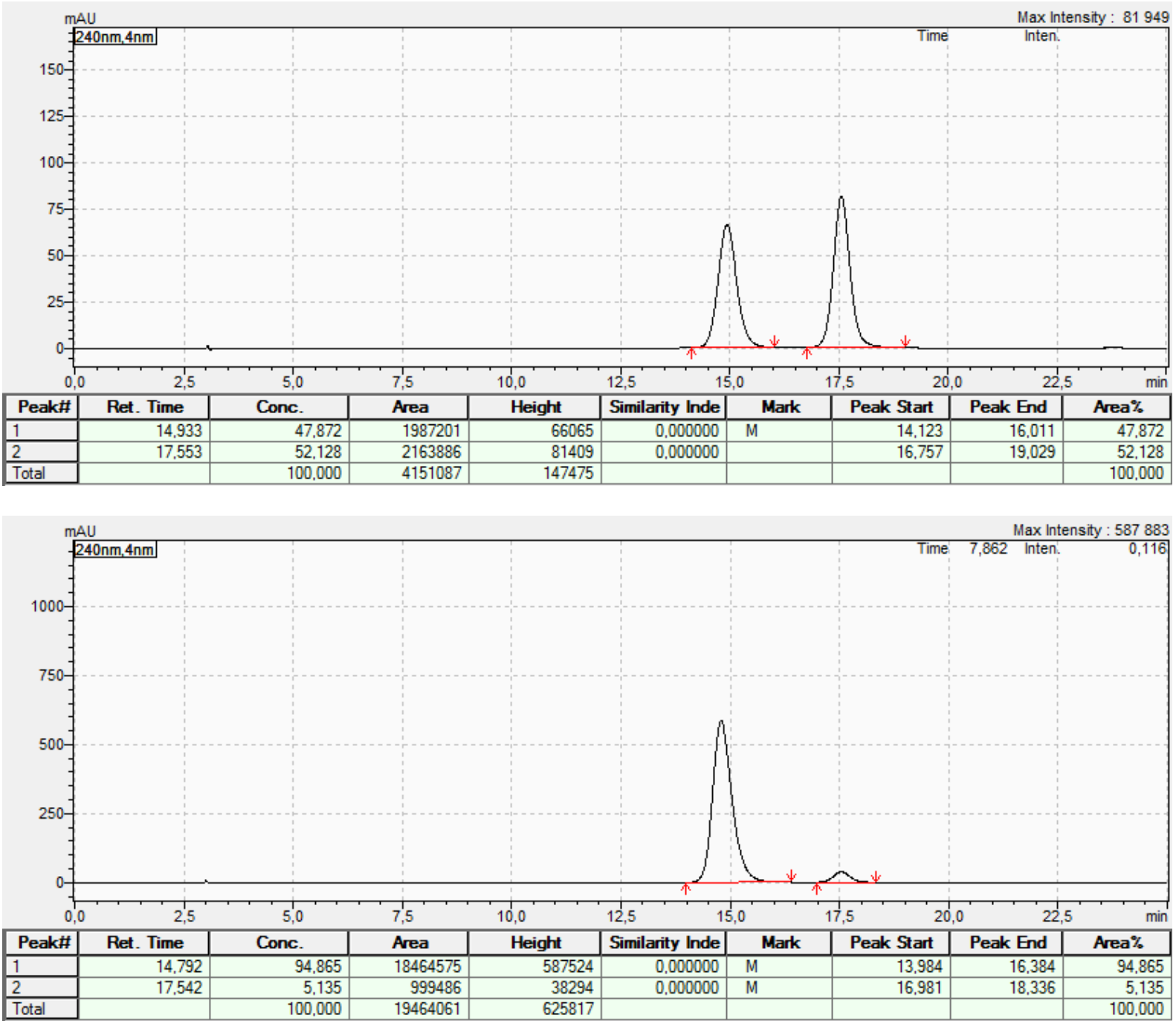
<smiles>CCOC(=O)[C@@]12CC(=O)CC(c3ccc(Br)cc3)[C@]1(C(=O)OCC)Sc1ccccc1C2=O</smiles>

3ag: Column IB, n-heptane: $i \operatorname{PrOH} 80: 20, \mathrm{~V}=1 \mathrm{~mL} / \mathrm{min}, \mathrm{T}_{\text {oven }}=25^{\circ} \mathrm{C}, 240$ $\mathrm{nm}, \mathrm{t}_{\mathrm{R}}=9.4,10.8 \min , e e=93 \%$
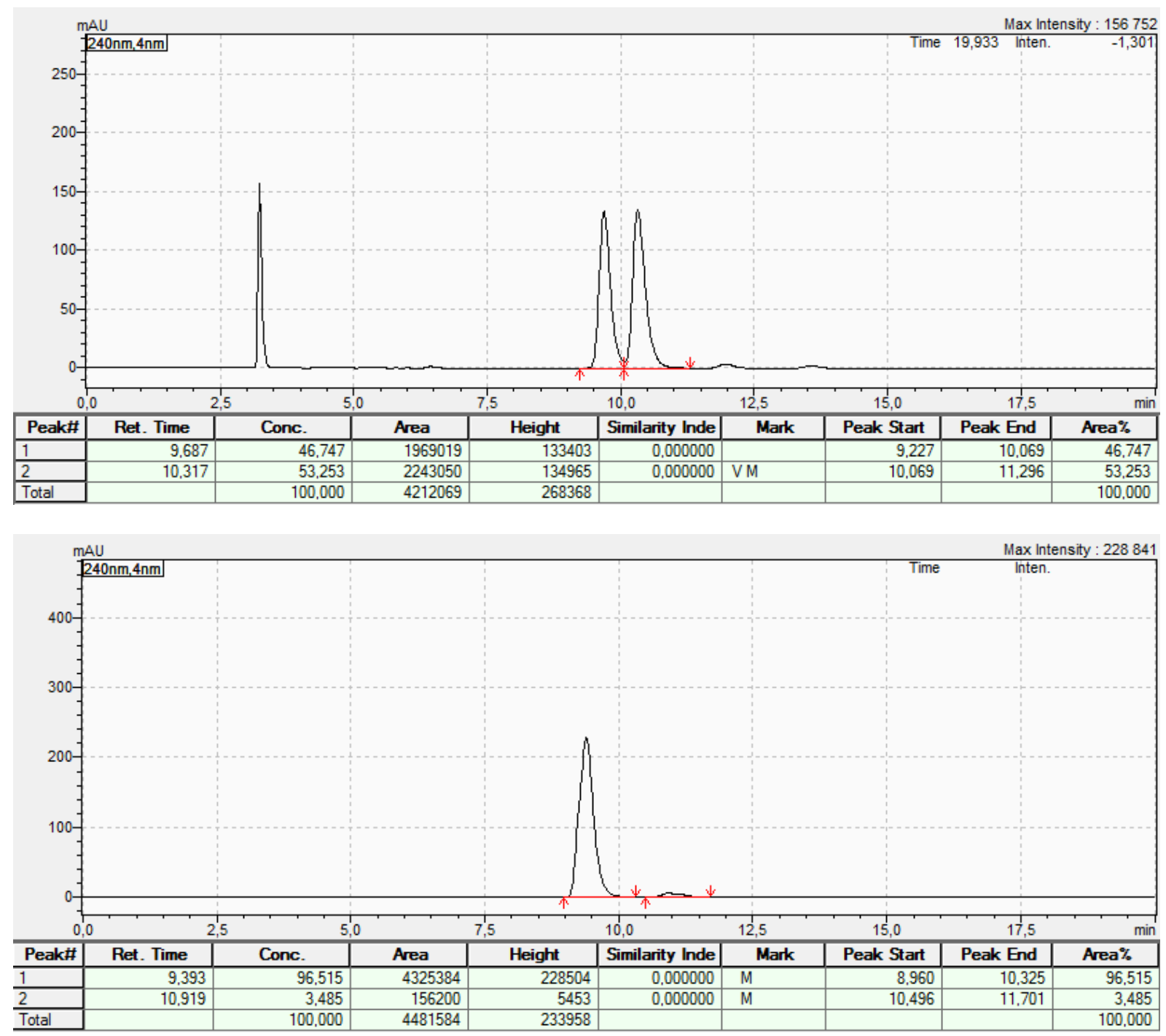


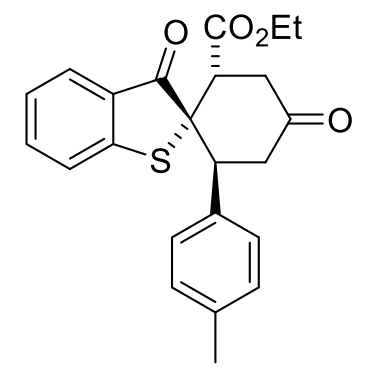

3ah: Column IC, n-heptane: $i \operatorname{PrOH} 80: 20, \mathrm{~V}=1 \mathrm{~mL} / \mathrm{min}, \mathrm{T}_{\text {oven }}=25^{\circ} \mathrm{C}, 210$ $\mathrm{nm}, \mathrm{t}_{\mathrm{R}}=18.1,22.0 \min , e e=96 \%$
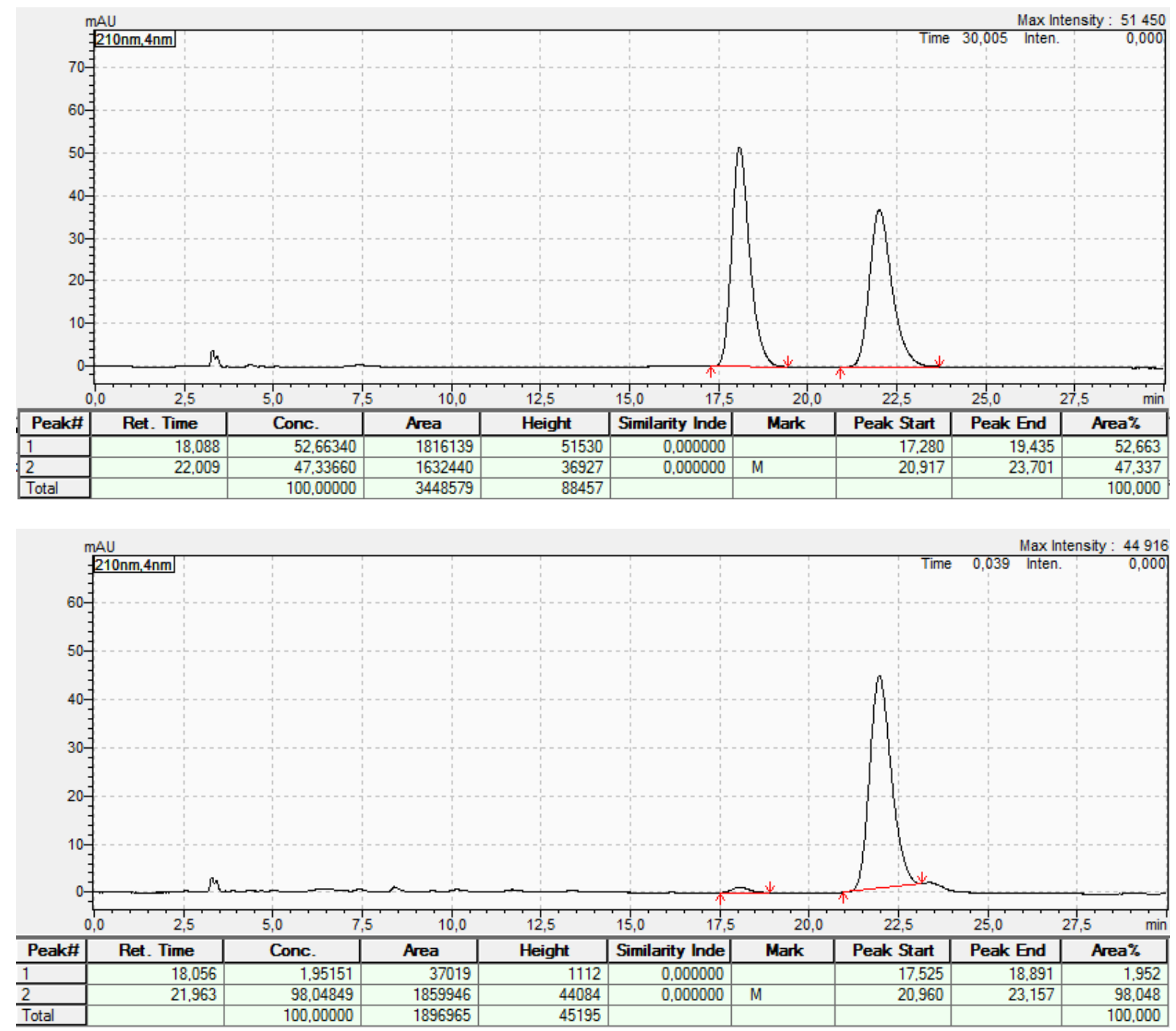


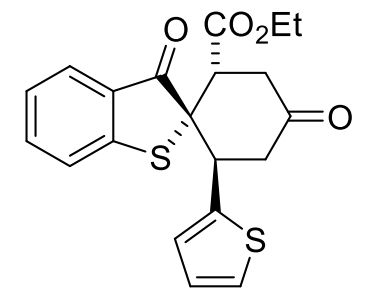

3ai: Column IC, n-heptane: $i \operatorname{PrOH} 80: 20, \mathrm{~V}=1 \mathrm{~mL} / \mathrm{min}, \mathrm{T}_{\text {oven }}=25^{\circ} \mathrm{C}, 240$ $\mathrm{nm}, \mathrm{t}_{\mathrm{R}}=18.5,21.4 \min , e e=95 \%$
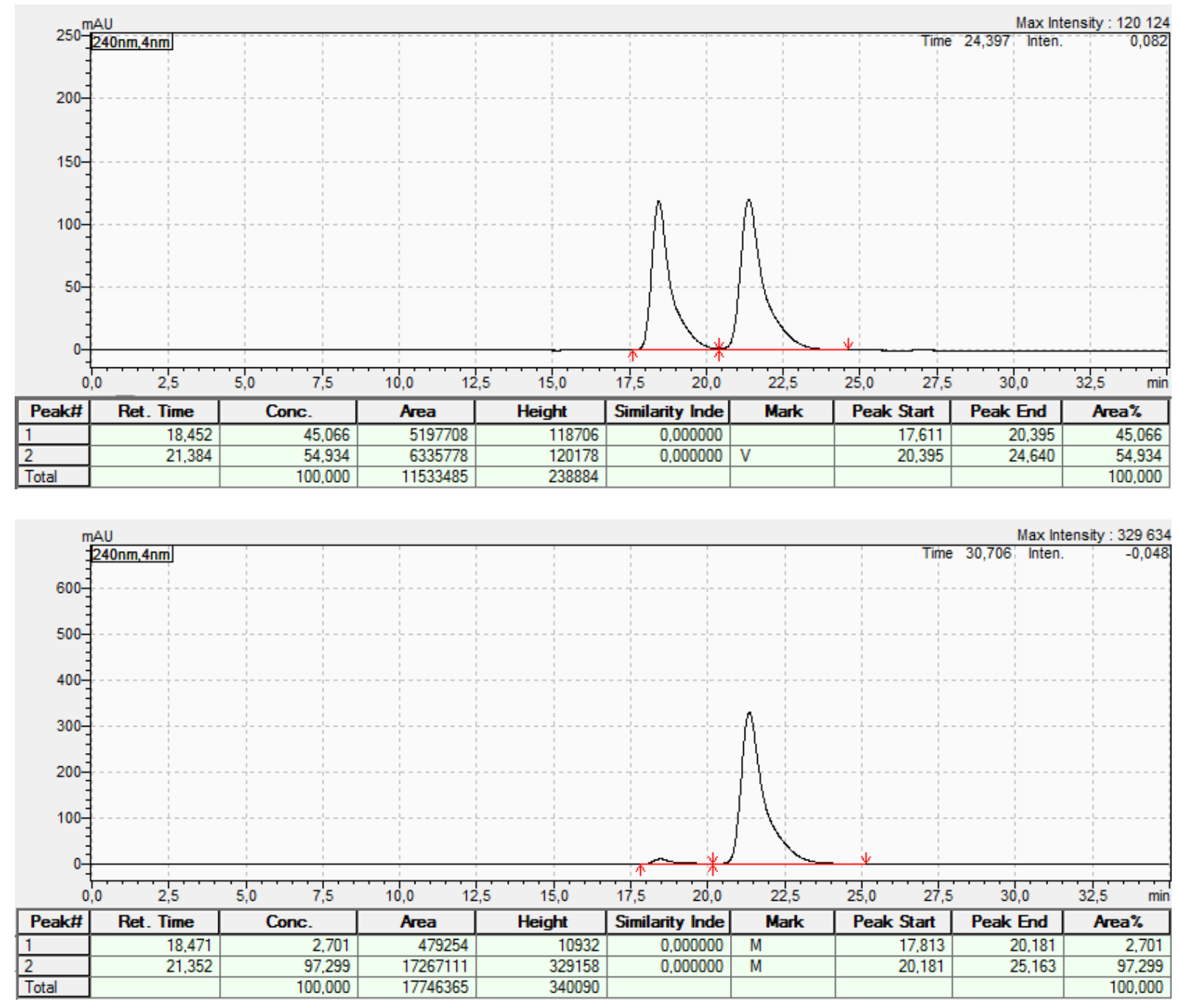


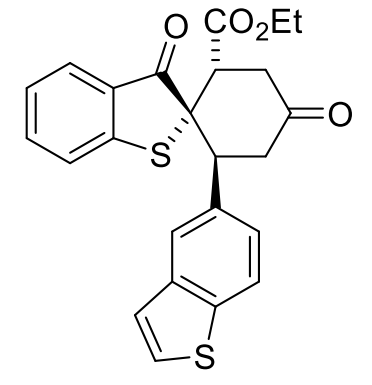

3aj: Column IC, n-heptane: $i \operatorname{PrOH} 80: 20, \mathrm{~V}=1 \mathrm{~mL} / \mathrm{min}, \mathrm{T}_{\text {oven }}=25^{\circ} \mathrm{C}, 254$ $\mathrm{nm}, \mathrm{t}_{\mathrm{R}}=23.6,26.1 \mathrm{~min}, e e=95 \%$
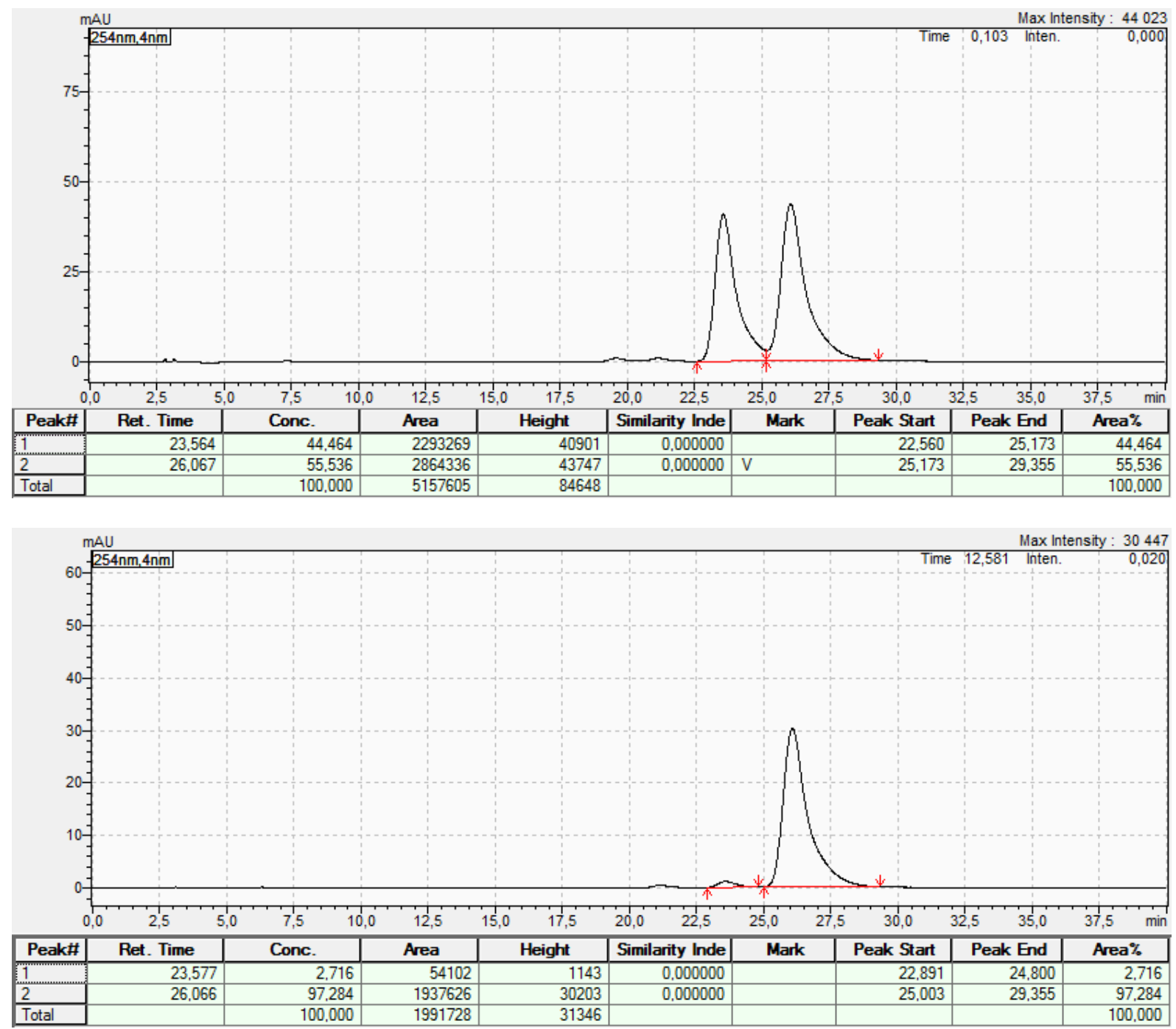
<smiles>O=C1CC(C(=O)c2ccccc2)[C@]2(Sc3ccccc3C2=O)[C@@H](c2ccccc2)C1</smiles>

3da: Column IA, n-heptane: $i \operatorname{PrOH} 80: 20, \mathrm{~V}=1 \mathrm{~mL} / \mathrm{min}, \mathrm{T}_{\text {oven }}=25^{\circ} \mathrm{C}, 254$ $\mathrm{nm}, \mathrm{t}_{\mathrm{R}}=10.1,12.3 \mathrm{~min}, e e=85 \%$
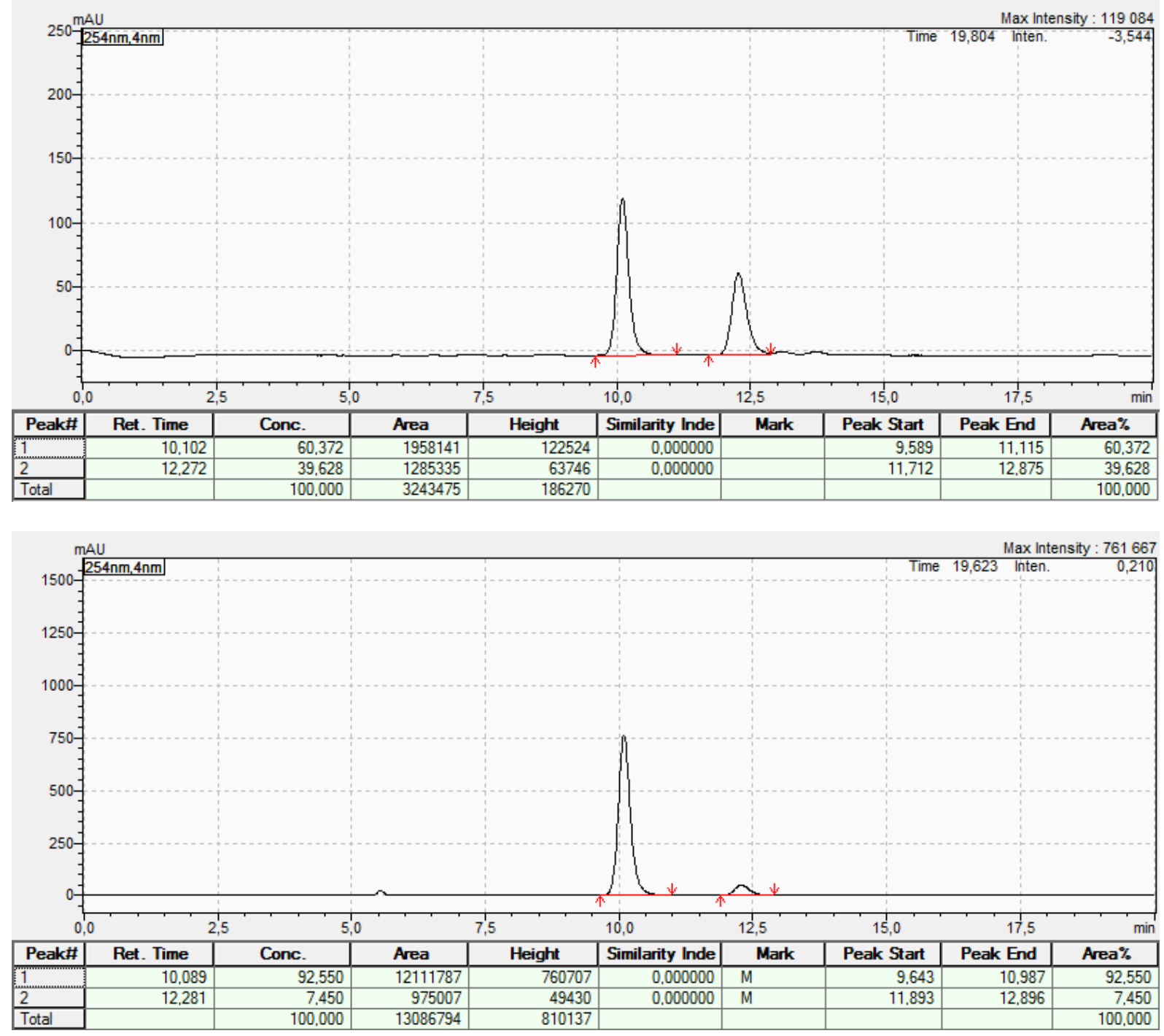


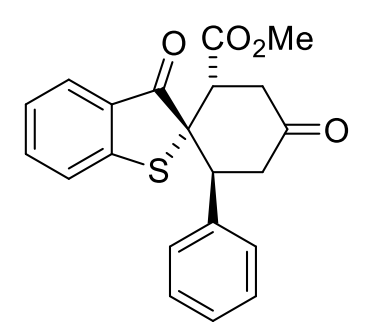

3ea: Column IA, n-heptane: $i \operatorname{PrOH} 90: 10, \mathrm{~V}=1 \mathrm{~mL} / \mathrm{min}, \mathrm{T}_{\text {oven }}=25^{\circ} \mathrm{C}, 240$ $\mathrm{nm}, \mathrm{t}_{\mathrm{R}}=12.1,14.5 \min , e e=95 \%$
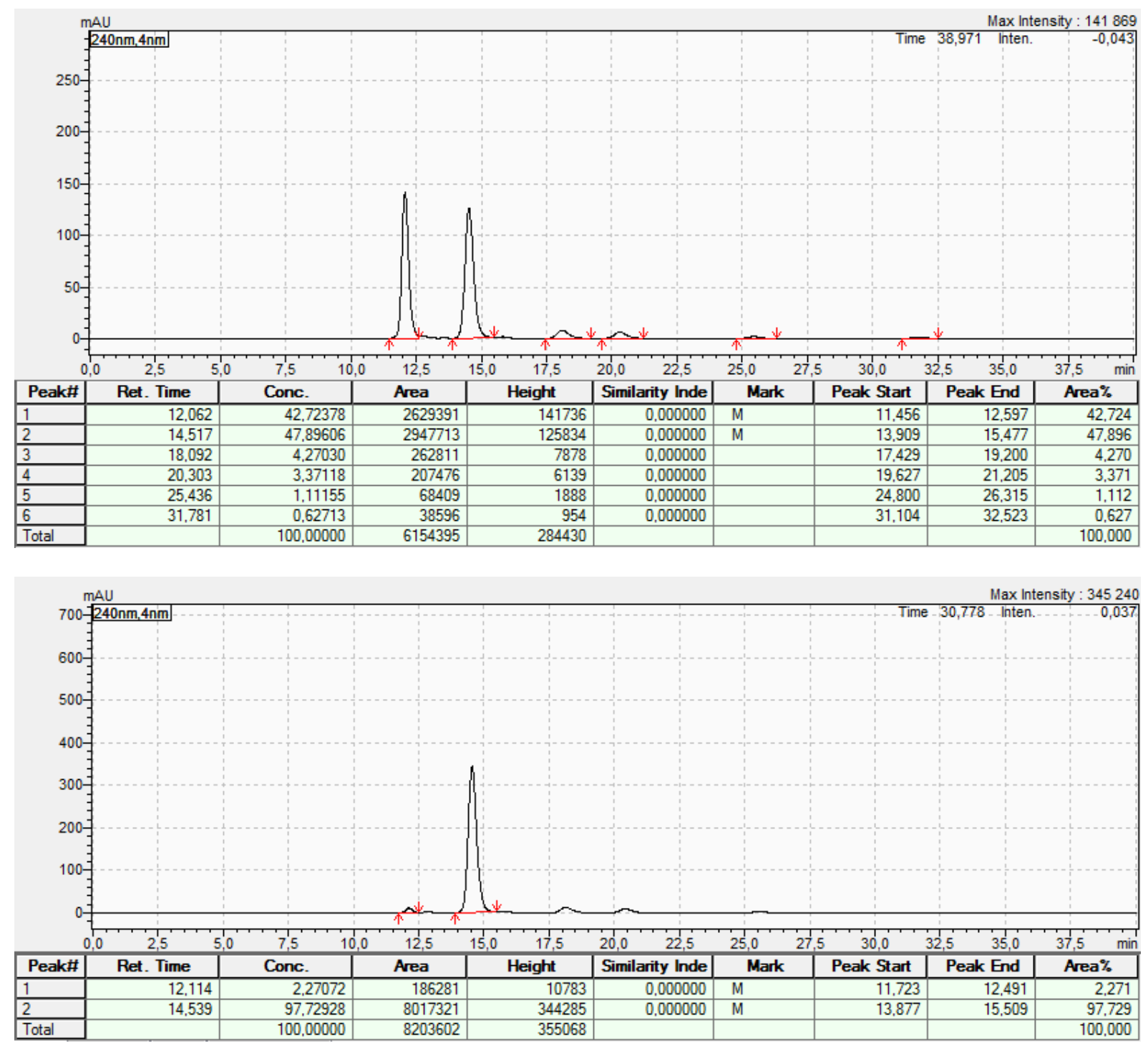


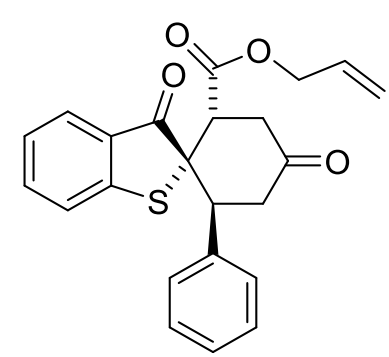

3fa: Column IA, n-heptane: $i \operatorname{PrOH} 90: 10, \mathrm{~V}=1 \mathrm{~mL} / \mathrm{min}, \mathrm{T}_{\text {oven }}=25^{\circ} \mathrm{C}, 240$ $\mathrm{nm}, \mathrm{t}_{\mathrm{R}}=12.0,14.1 \mathrm{~min}, e e=95 \%$
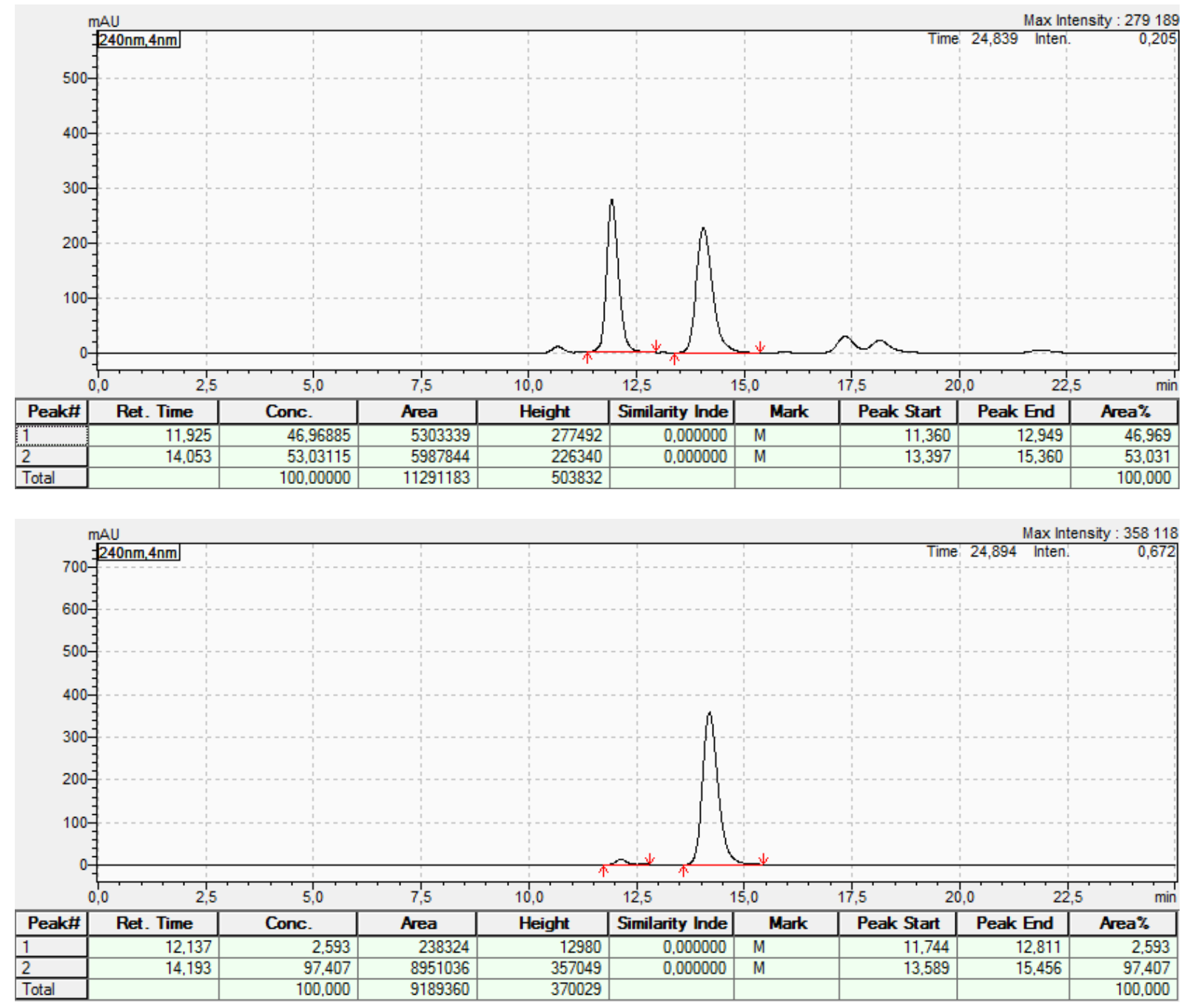
<smiles>N#C[C@@]12CC(=O)C[C@@H](c3ccccc3)[C@@]1(c1ccccc1)Sc1ccccc1C2=O</smiles>

3ga: Column IC, $\mathrm{n}$-heptane: $i \operatorname{PrOH} 60: 40, \mathrm{~V}=1 \mathrm{~mL} / \mathrm{min}, \mathrm{T}_{\text {oven }}=25^{\circ} \mathrm{C}, 240$ $\mathrm{nm}, \mathrm{t}_{\mathrm{R}}=17.5,26.0 \mathrm{~min}, e e=97 \%$
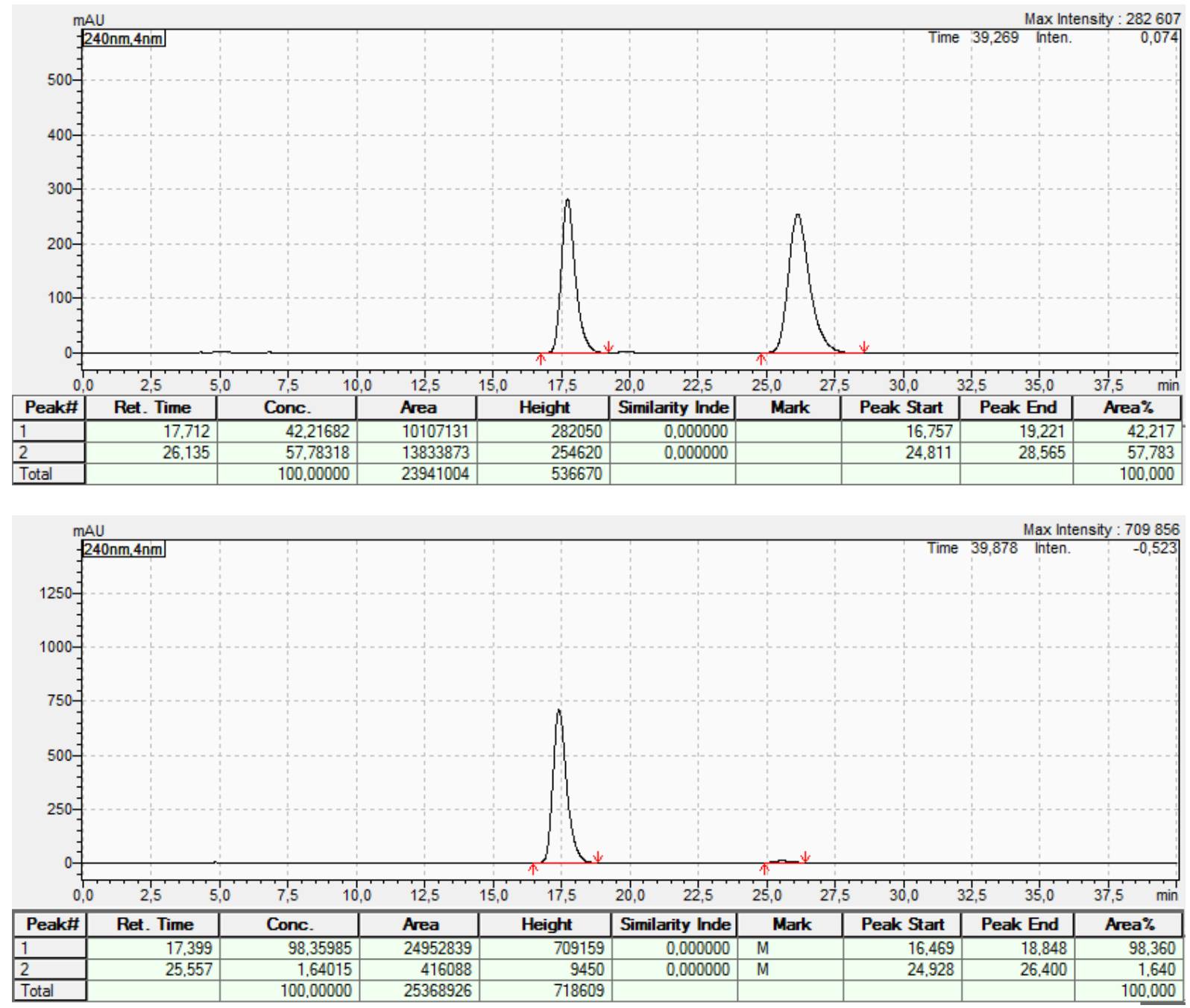


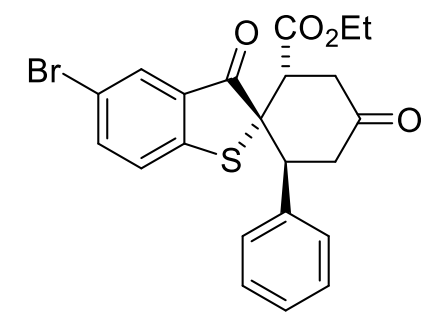

3ha: Column IA, n-heptane: $i \operatorname{PrOH} 80: 20, \mathrm{~V}=1 \mathrm{~mL} / \mathrm{min}, \mathrm{T}_{\text {oven }}=25^{\circ} \mathrm{C}$, $240 \mathrm{~nm}, \mathrm{t}_{\mathrm{R}}=8.6,9.6 \mathrm{~min}, e e=92 \%$
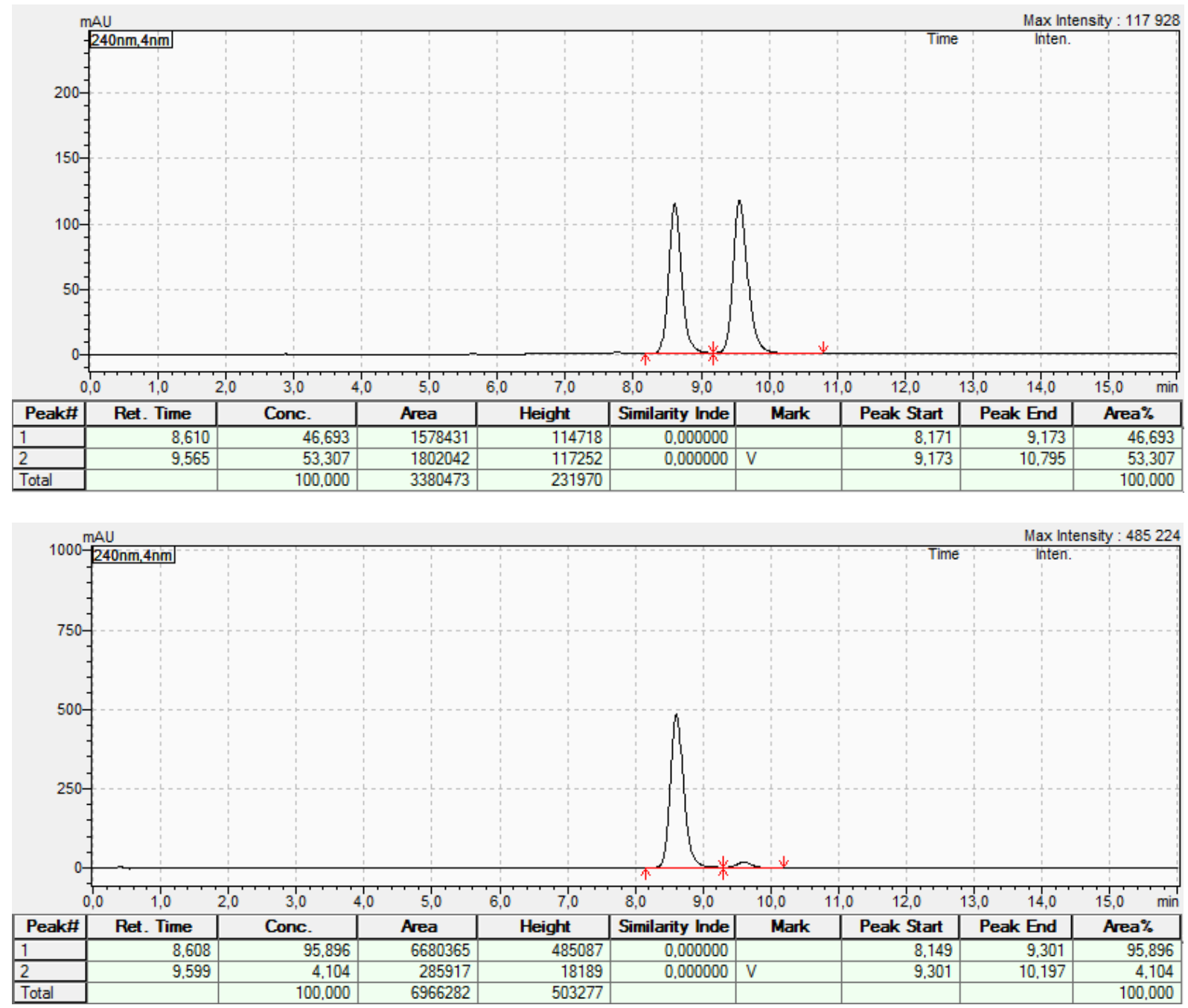


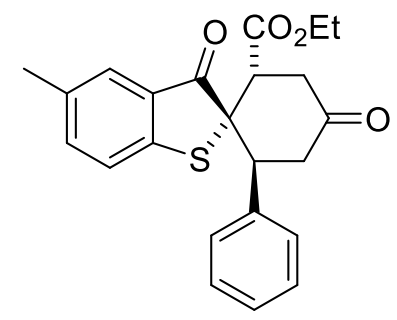

3ia: Column IA, n-heptane: $i \operatorname{PrOH} 80: 20, \mathrm{~V}=0.5 \mathrm{~mL} / \mathrm{min}, \mathrm{T}_{\text {oven }}=25^{\circ} \mathrm{C}$, $240 \mathrm{~nm}, \mathrm{t}_{\mathrm{R}}=16.2,17.2 \mathrm{~min}, e e=92 \%$
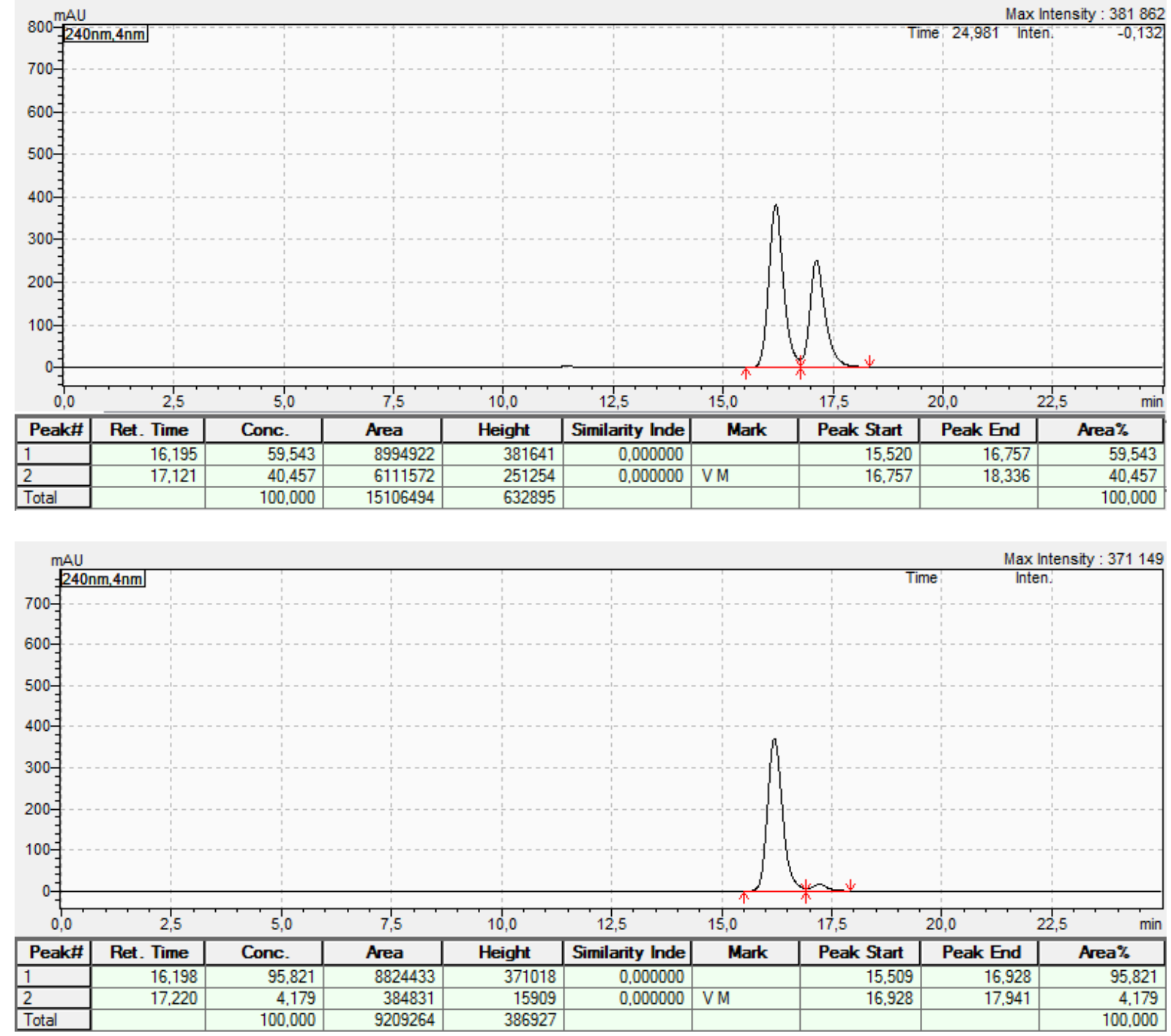
<smiles>CCOC(=O)[C@@H]1CC(=O)C[C@H](c2ccccc2)[C@@]12Sc1cccc(C)c1C2=O</smiles>

3ja: Column IA, n-heptane: $i \operatorname{PrOH} 80: 20, \mathrm{~V}=1 \mathrm{~mL} / \mathrm{min}, \mathrm{T}_{\text {oven }}=25^{\circ} \mathrm{C}, 240$ $\mathrm{nm}, \mathrm{t}_{\mathrm{R}}=7.3,7.7 \mathrm{~min}, e e=90 \%$
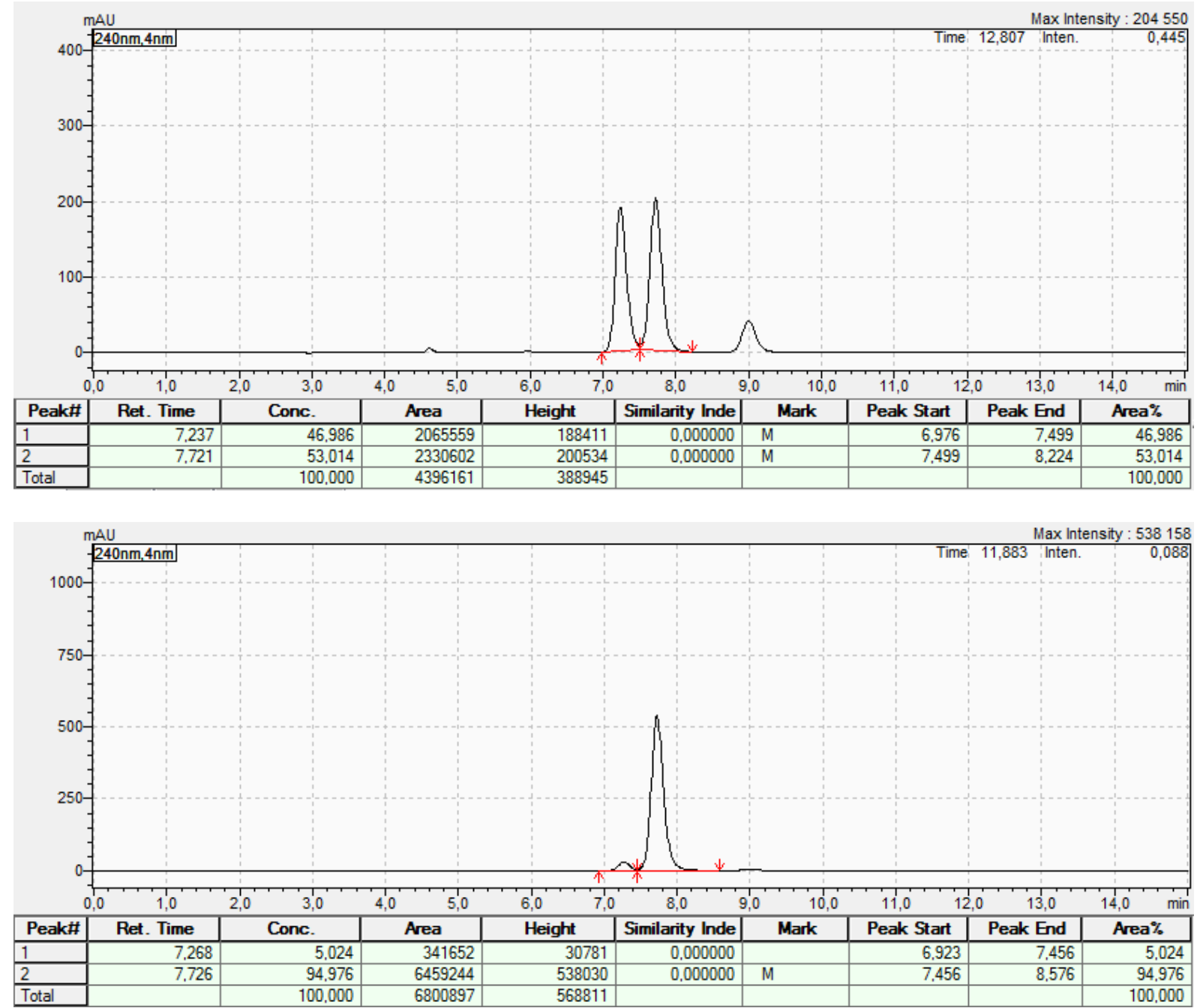
<smiles>CCOC(=O)C1CC(=O)CC(c2ccccc2)[C@@]12Sc1cc(C)ccc1C2=O</smiles>

3ka: Column IA, n-heptane: $i \mathrm{PrOH} 80: 20, \mathrm{~V}=1 \mathrm{~mL} / \mathrm{min}, \mathrm{T}_{\text {oven }}=25^{\circ} \mathrm{C}, 240$ $\mathrm{nm}, \mathrm{t}_{\mathrm{R}}=8.2,9.8 \mathrm{~min}, e e=95 \%$
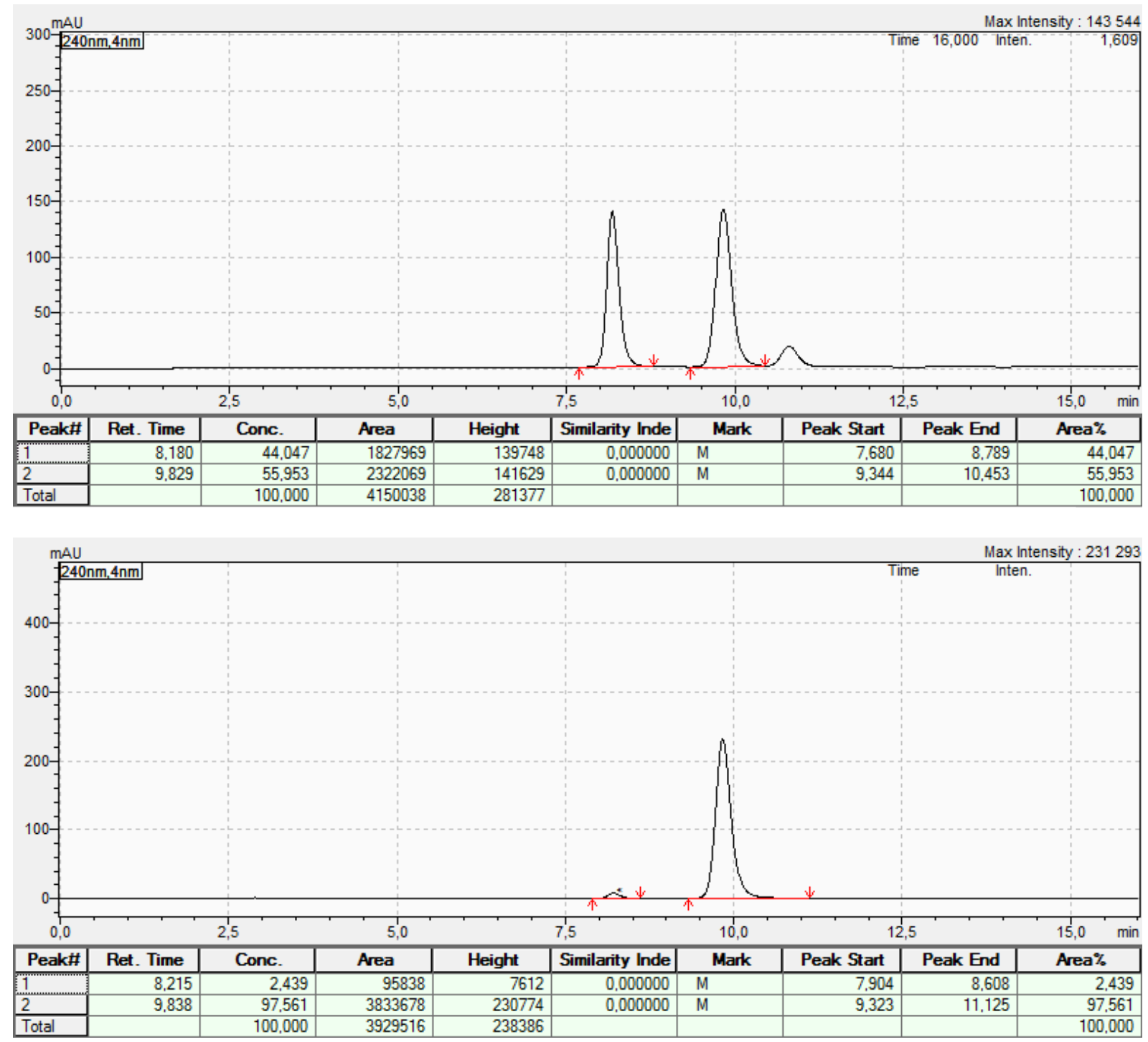
<smiles>CCOC(=O)C1CC(=O)CC(c2ccccc2)[C@@]12Sc1c(C)cccc1C2=O</smiles>

3la: Column IB, n-heptane: $i \operatorname{PrOH} 80: 20, \mathrm{~V}=1 \mathrm{~mL} / \mathrm{min}, \mathrm{T}_{\text {oven }}=25^{\circ} \mathrm{C}, 240$ $\mathrm{nm}, \mathrm{t}_{\mathrm{R}}=7.0,8.5 \mathrm{~min}, e e=96 \%$
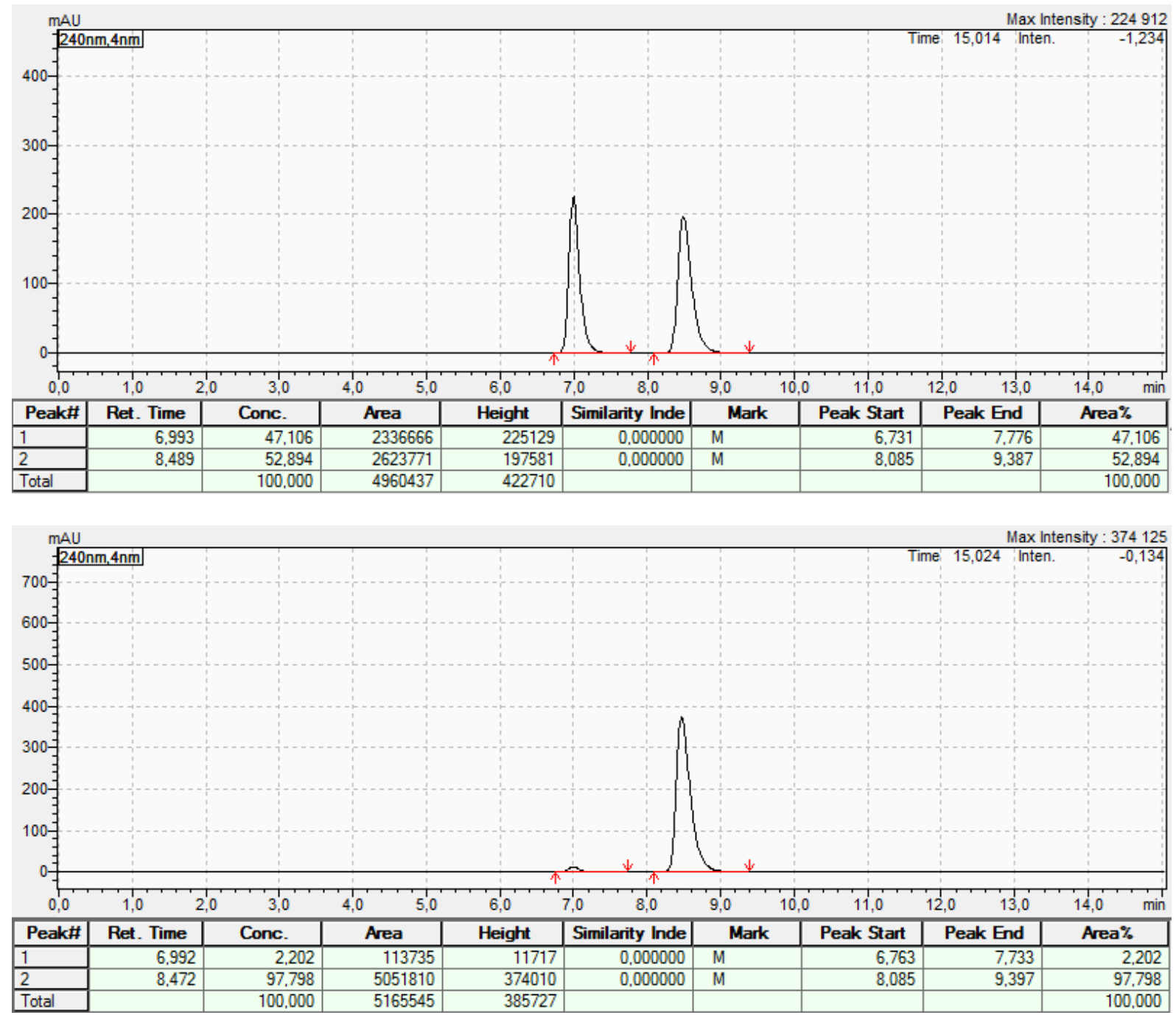


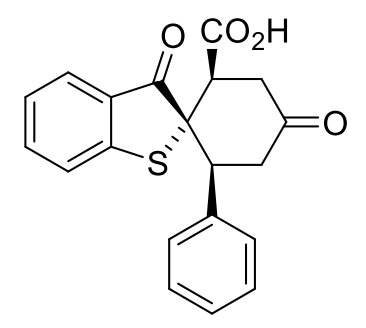

4'’aa: Determined as methyl ester and compared with compound 3ea.

Column IA, n-heptane: $i \operatorname{PrOH} 90: 10, \mathrm{~V}=1 \mathrm{~mL} / \mathrm{min}, \mathrm{T}_{\text {oven }}=25^{\circ} \mathrm{C}, 240 \mathrm{~nm}$, $\mathrm{t}_{\mathrm{R}}=25.4,31.7 \mathrm{~min}, d r=1 / 6.6 / 42.4$, ee $=82 \%$
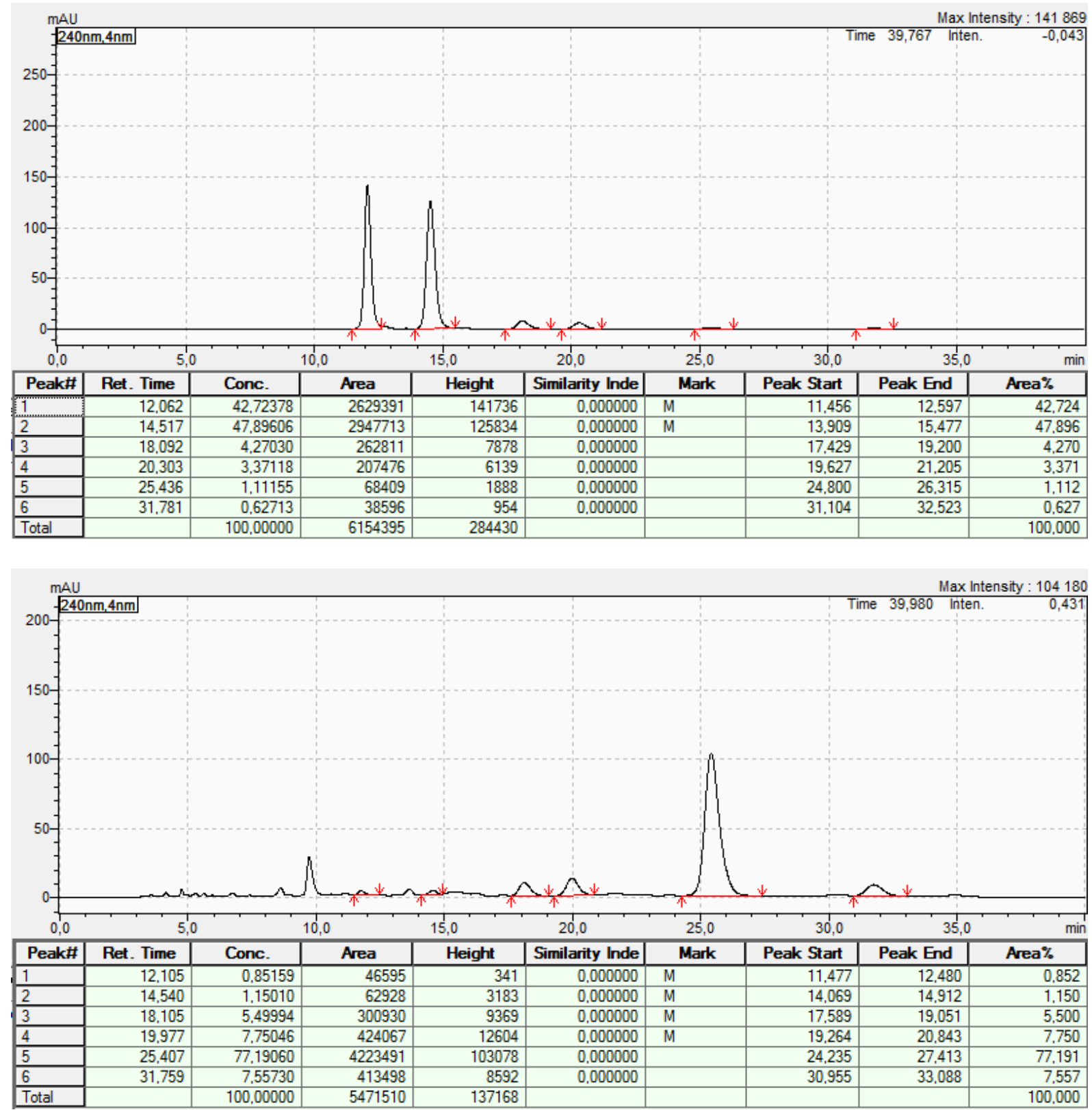


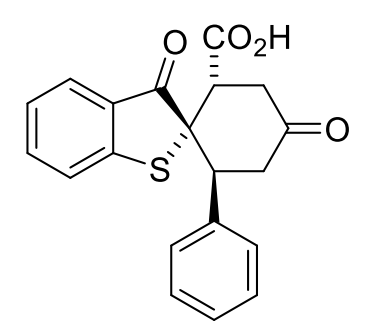

4aa: Determined as methyl ester and compared with compound 3ea.

Column IA, n-heptane: $i \operatorname{PrOH} 90: 10, \mathrm{~V}=1 \mathrm{~mL} / \mathrm{min}, \mathrm{T}_{\text {oven }}=25^{\circ} \mathrm{C}, 240 \mathrm{~nm}$, $\mathrm{t}_{\mathrm{R}}=12.1,14.5 \mathrm{~min}, e e=95 \%$
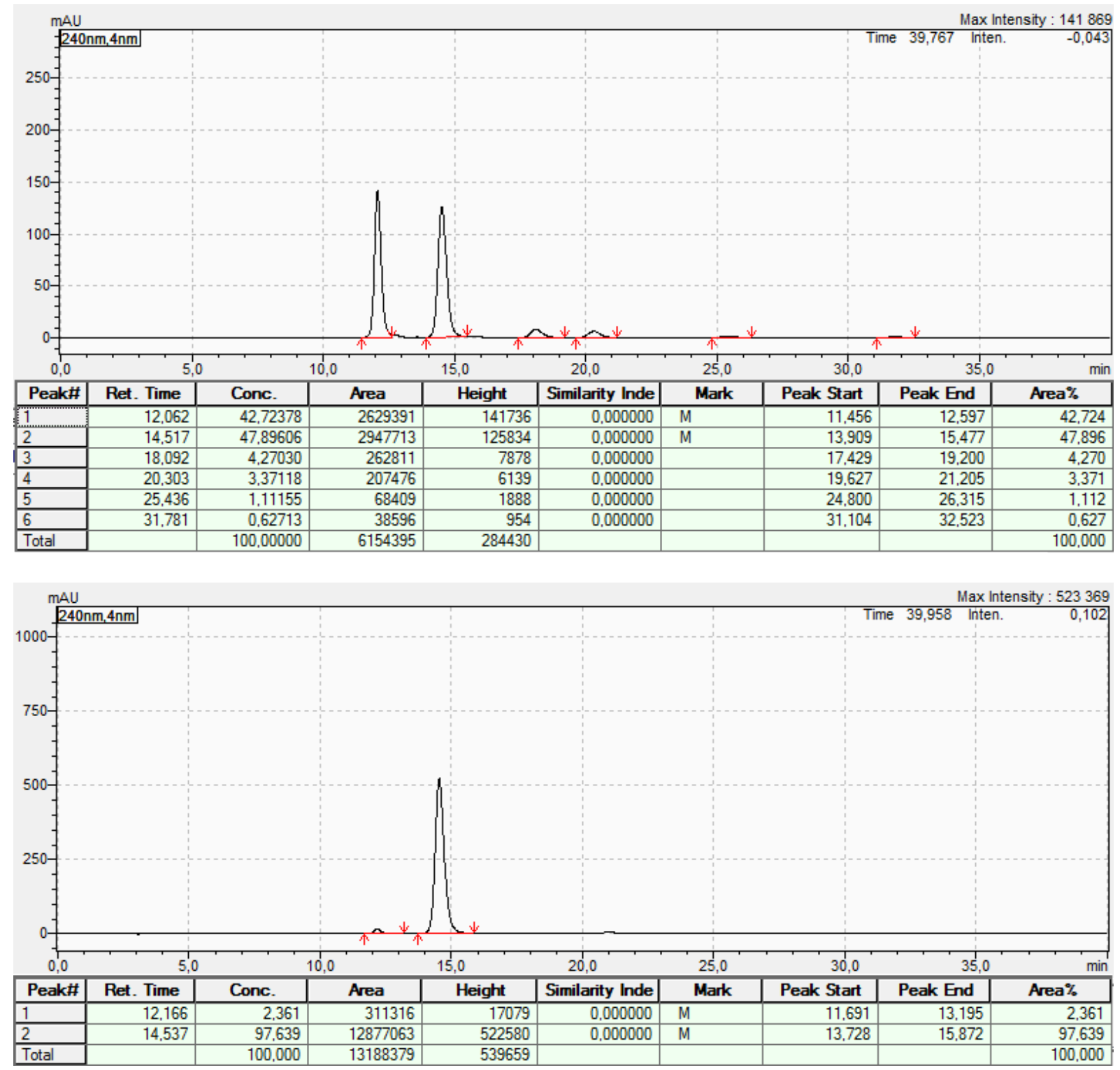


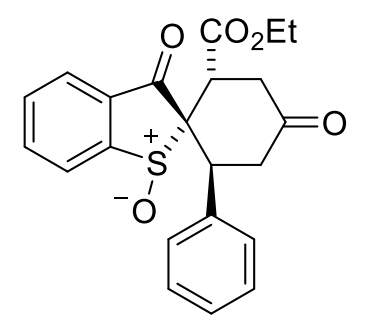

5a: Column IA, n-heptane: $i \operatorname{PrOH} 70: 30, \mathrm{~V}=1 \mathrm{~mL} / \mathrm{min}, \mathrm{T}_{\text {oven }}=25^{\circ} \mathrm{C}, 220 \mathrm{~nm}$, $\mathrm{t}_{\mathrm{R}}=11.7,18.0 \mathrm{~min}, e e=95 \%$
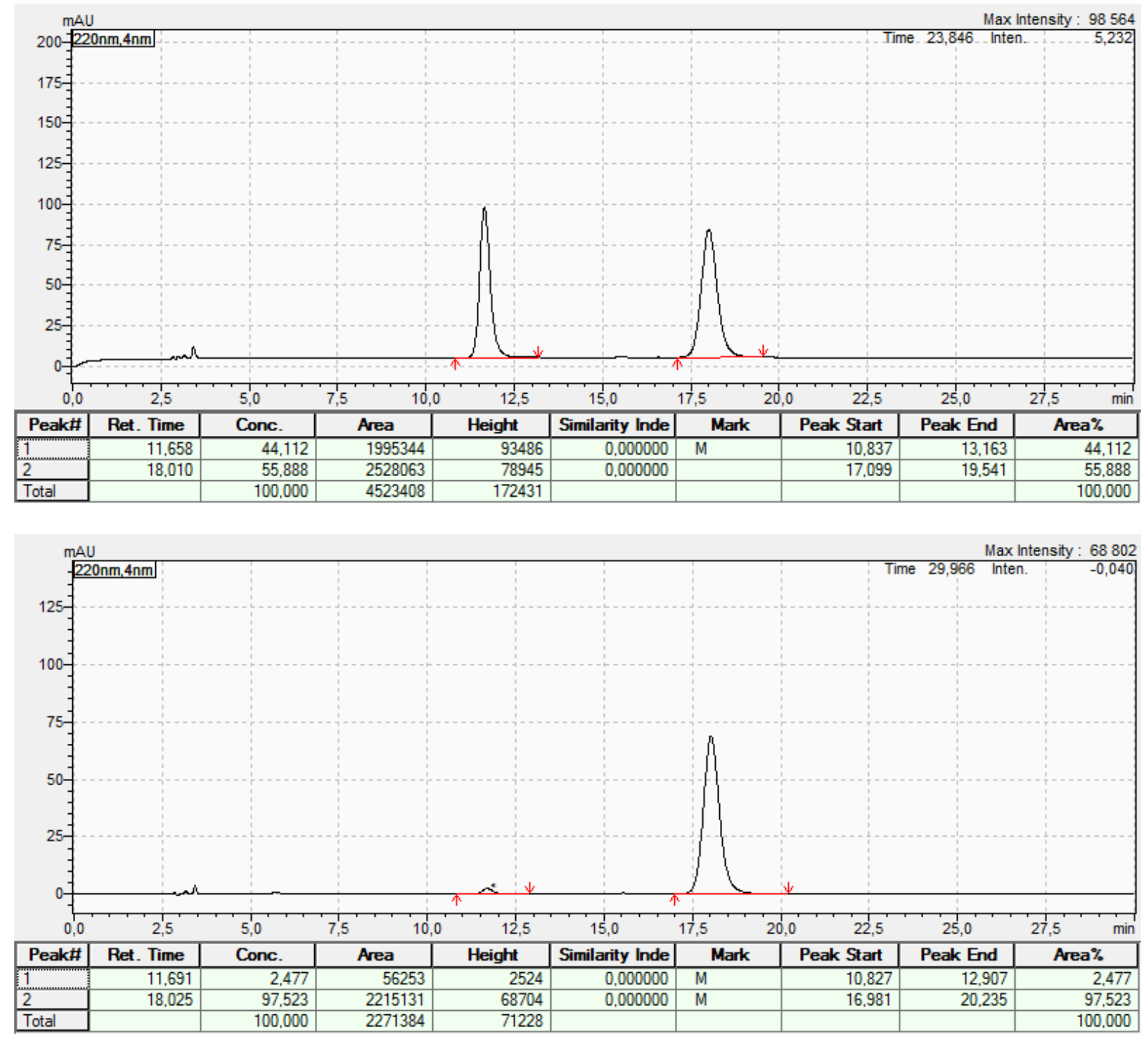


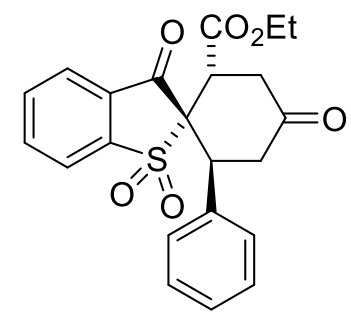

6a: Column IA, n-heptane: $i \operatorname{PrOH} 70: 30, \mathrm{~V}=1 \mathrm{~mL} / \mathrm{min}, \mathrm{T}_{\text {oven }}=25^{\circ} \mathrm{C}, 240 \mathrm{~nm}$, $\mathrm{t}_{\mathrm{R}}=13.4,18.4 \mathrm{~min}, e e=95 \%$
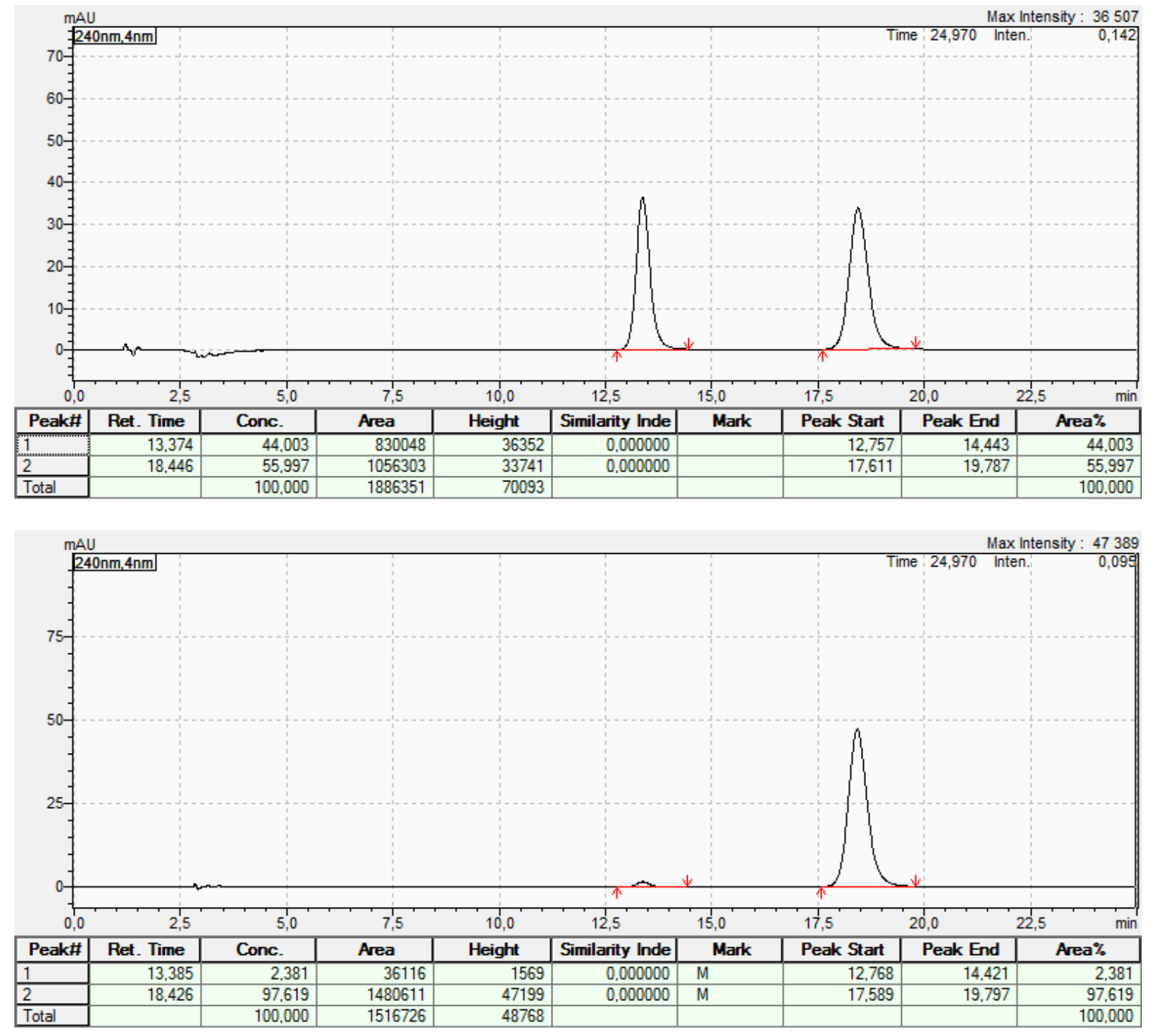
<smiles>CCOC(=O)[C@]12CC(=O)CC(c3ccccc3)[C@]1(c1ccccc1)Sc1ccc(-c3ccc(C)cc3)cc1C2=O</smiles>

7a:Column IA, n-heptane: $i \operatorname{PrOH} 80: 20, \mathrm{~V}=1 \mathrm{~mL} / \mathrm{min}, \mathrm{T}_{\text {oven }}=$ $25^{\circ} \mathrm{C}, 254 \mathrm{~nm}, \mathrm{t}_{\mathrm{R}}=12.1,14.5 \mathrm{~min}, e e=92 \%$
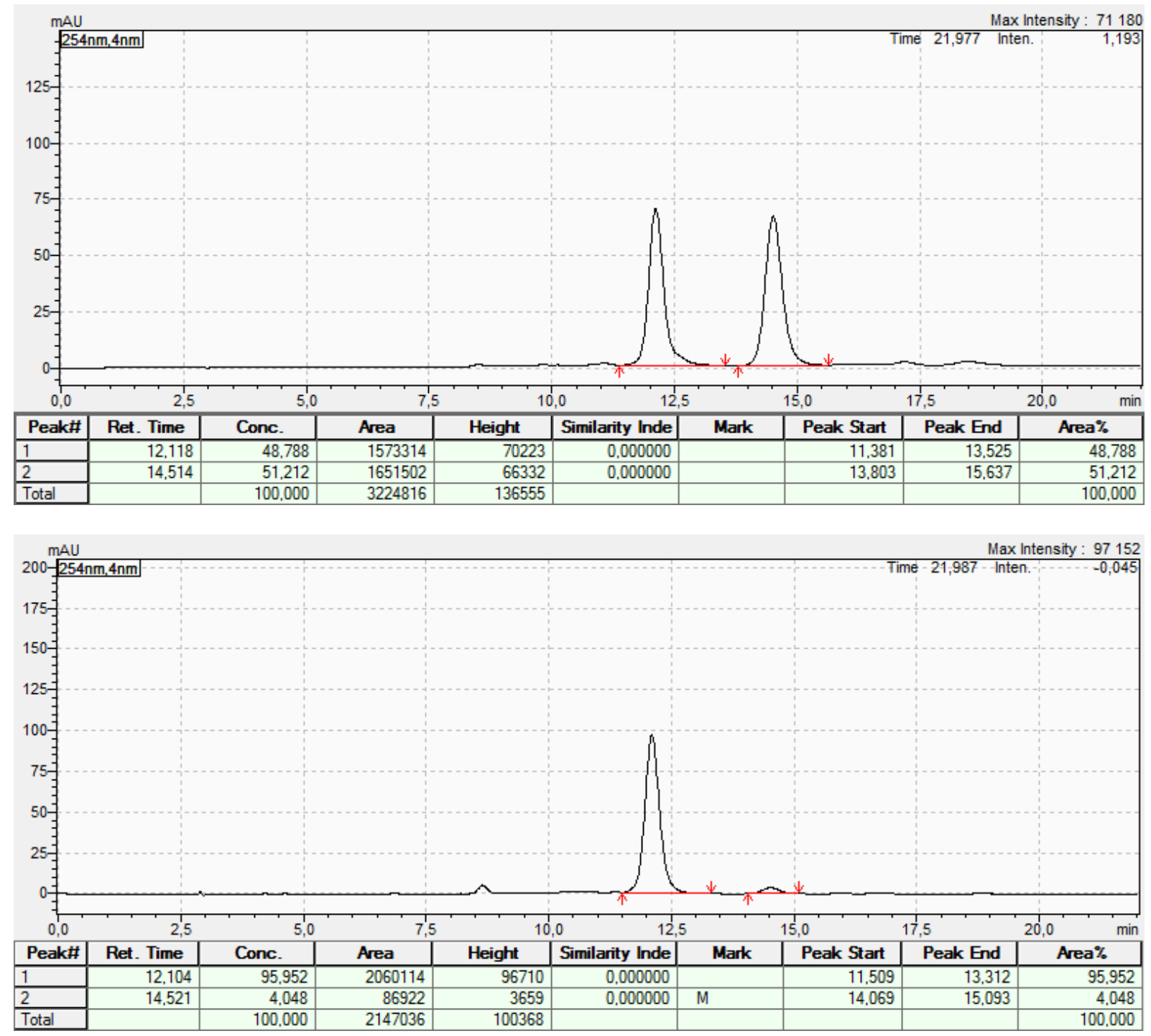